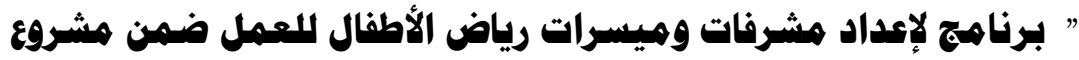

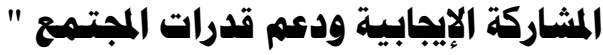

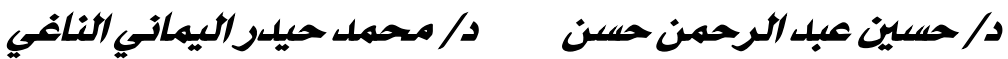

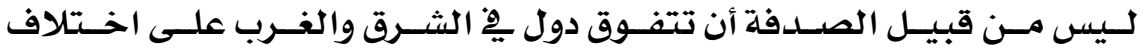

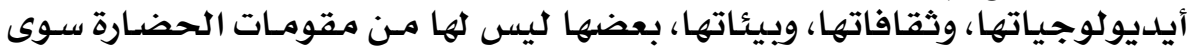

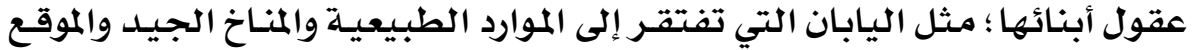

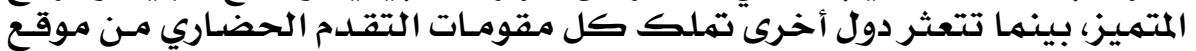

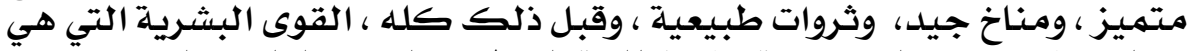

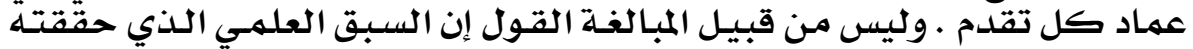

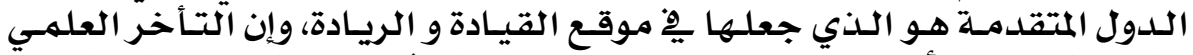

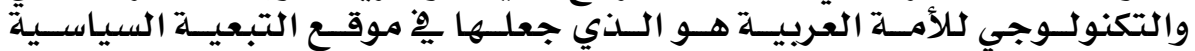

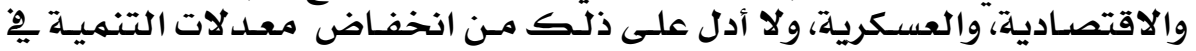

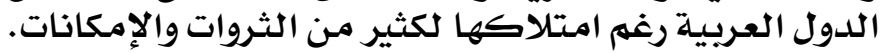

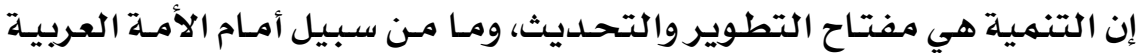

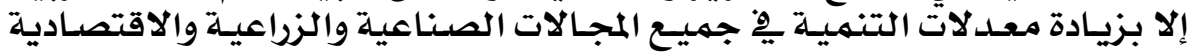

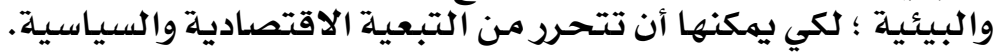

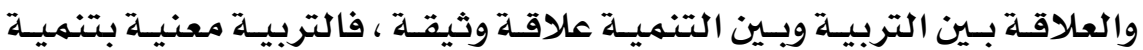

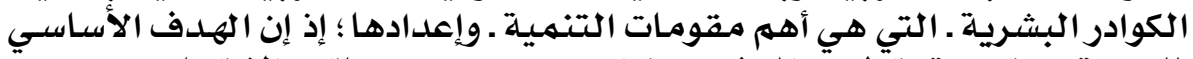

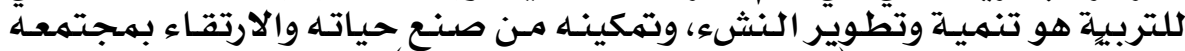

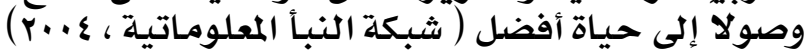

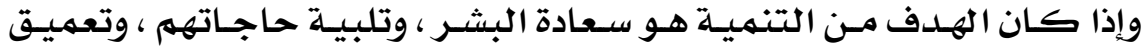

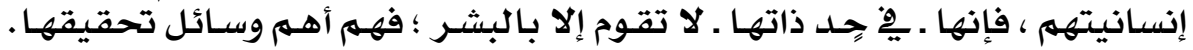

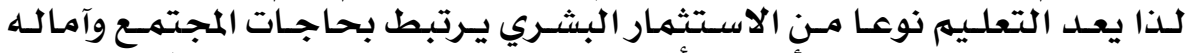

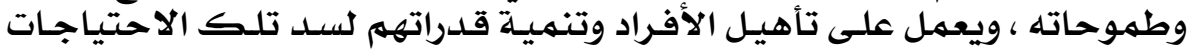

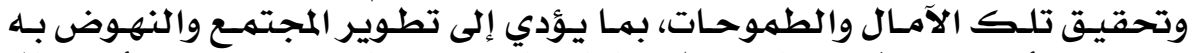

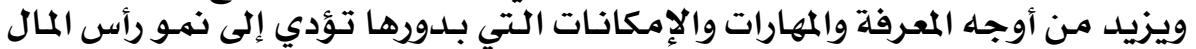

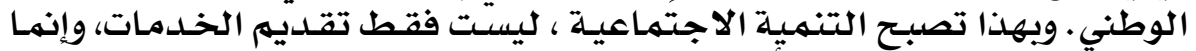

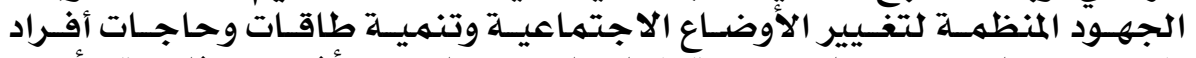

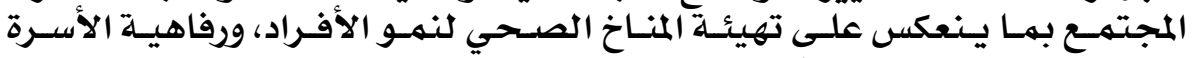

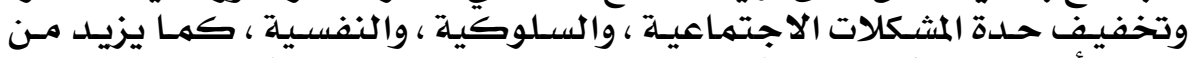

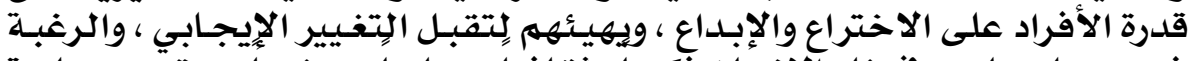

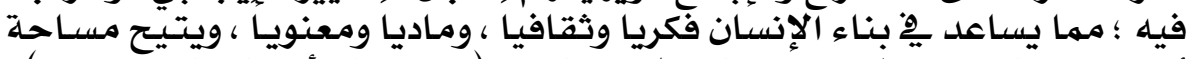

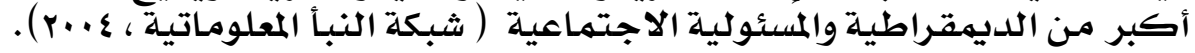

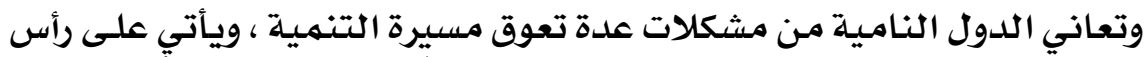

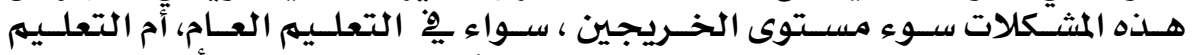

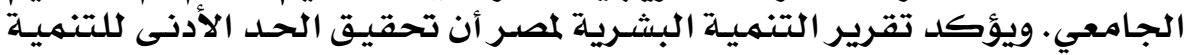

\section{$10 Y$}

هوأسات عربية في ألتبية وعiم أنففي (ASEP) 


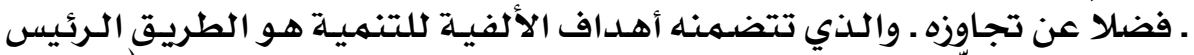

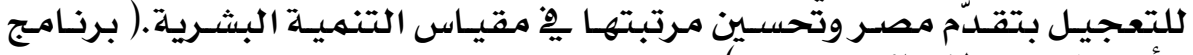

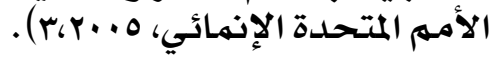

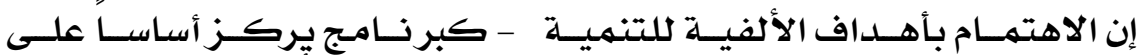

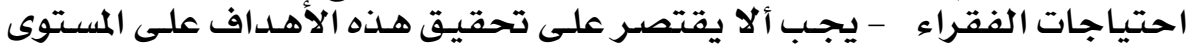

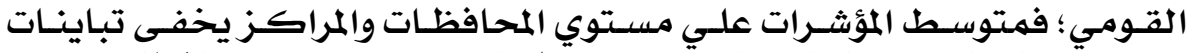

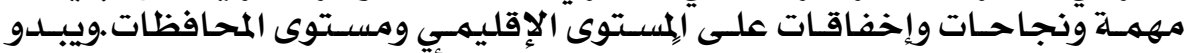

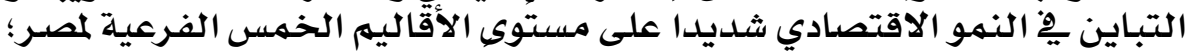

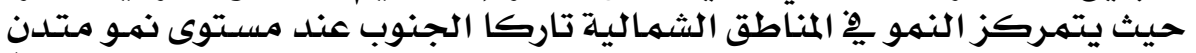

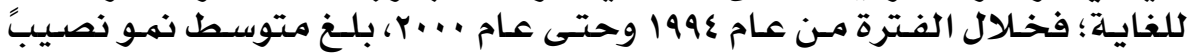

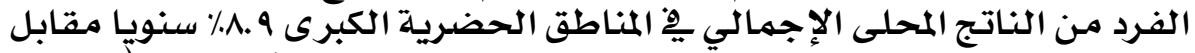

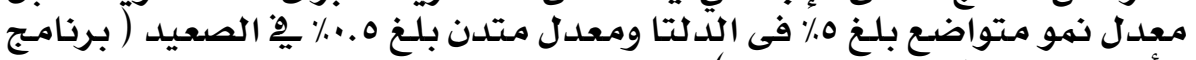

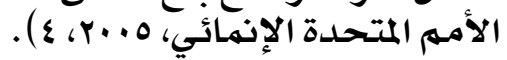

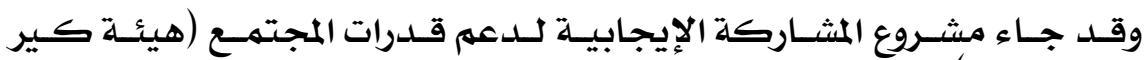

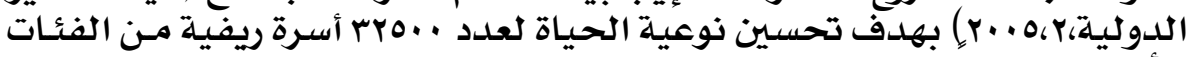

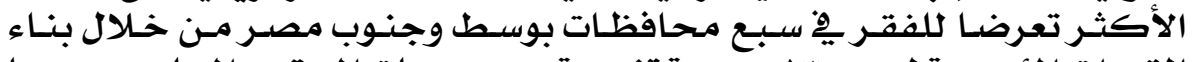

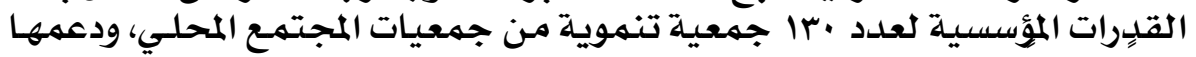

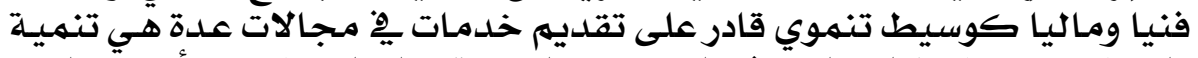

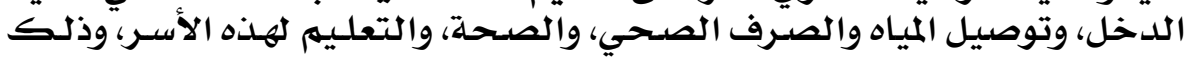

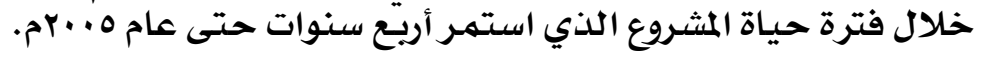

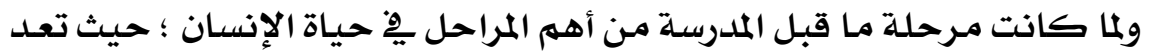

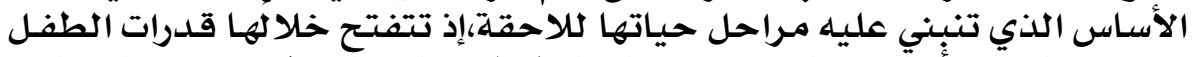

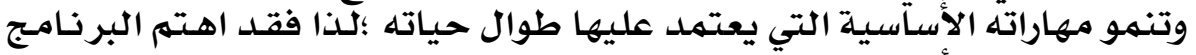

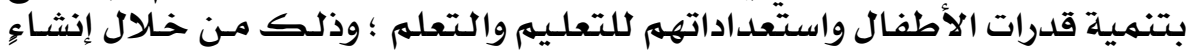

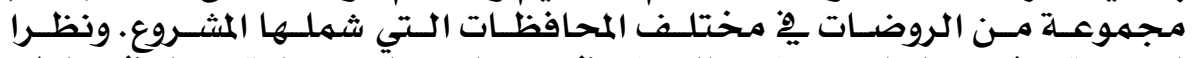

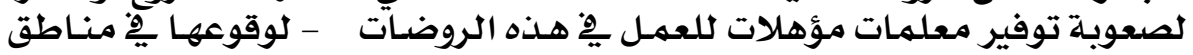

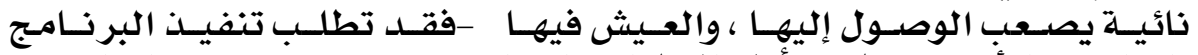

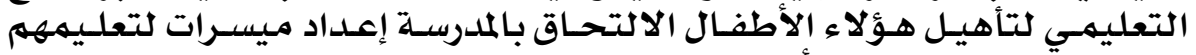

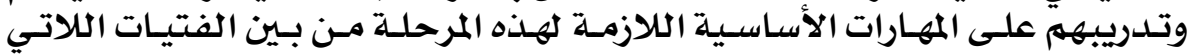

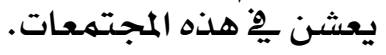

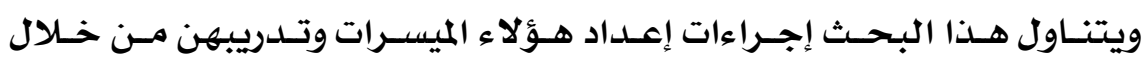

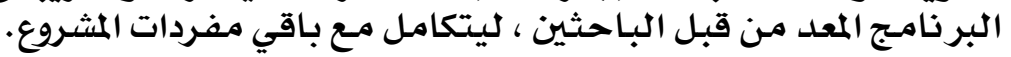

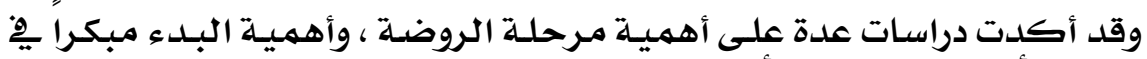

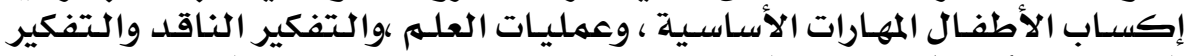

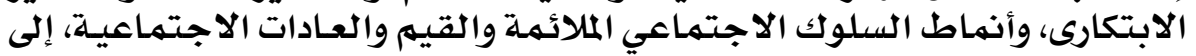

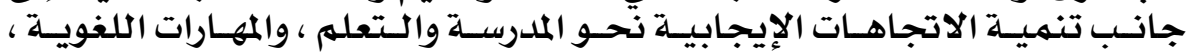

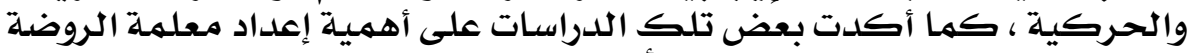

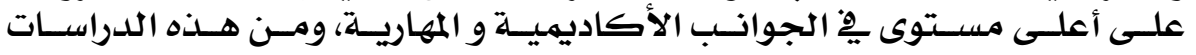

\section{$1 \odot \varepsilon$}




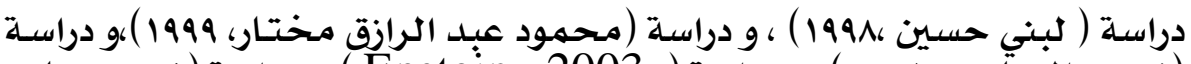

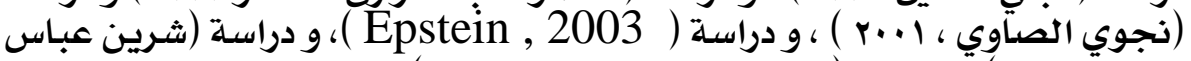

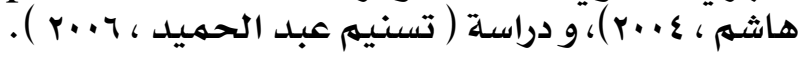

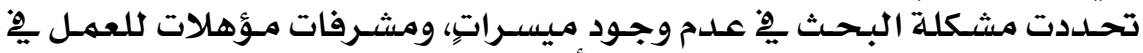

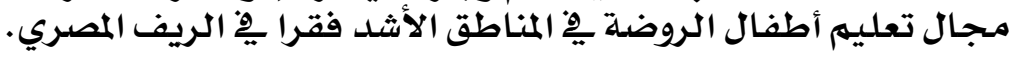

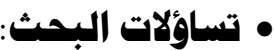

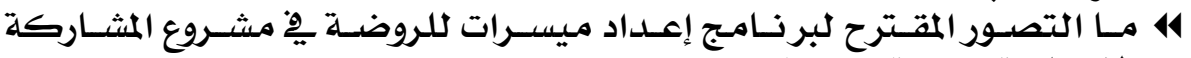

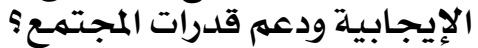

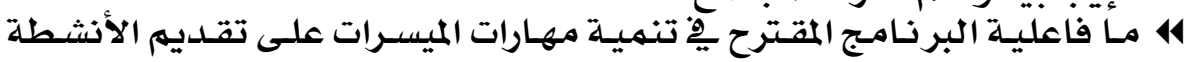

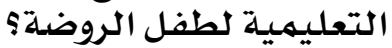

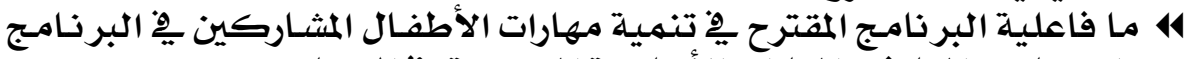

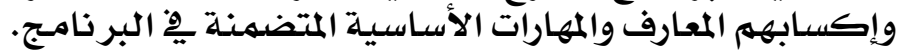

41 تصـميهم برنـامـج لتتنميـة مهارات الميسـرات لتقـديم الأنشطة التعليميـة لطفل مرحلة الروضية.

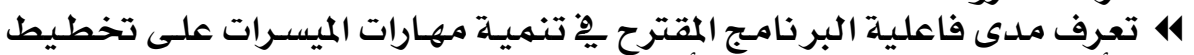

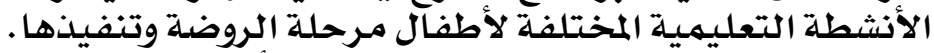

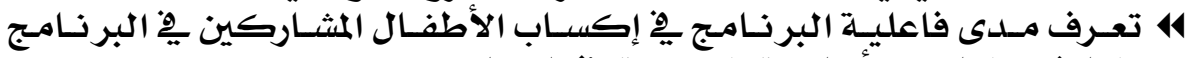

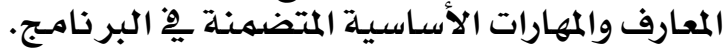

$$
\begin{aligned}
& \text { • حدود البحث : } \\
& \text { اقتصر البـحث الحئ الحالي على: }
\end{aligned}
$$

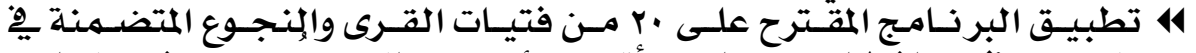

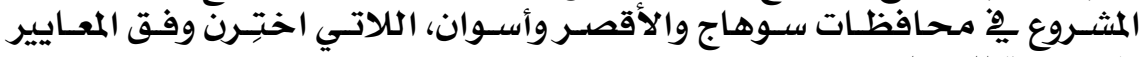

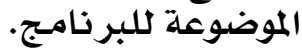

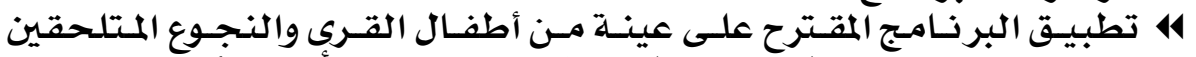

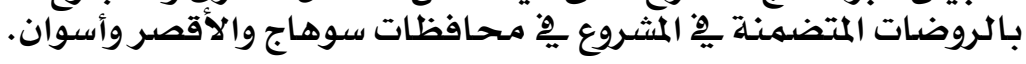

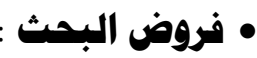

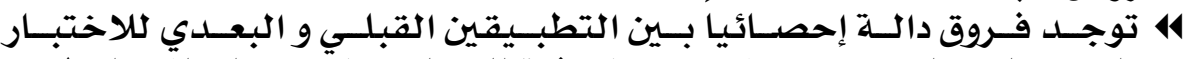

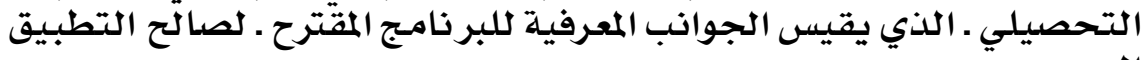
البعدي.

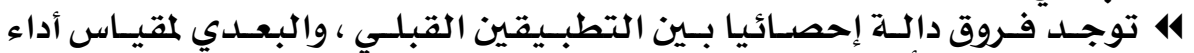

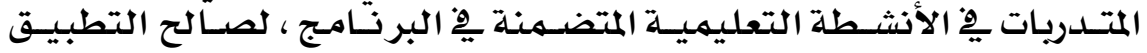
البعدي.

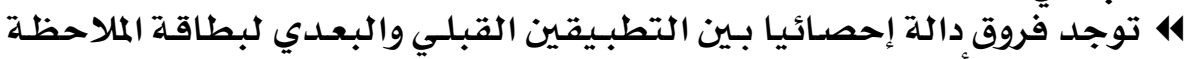

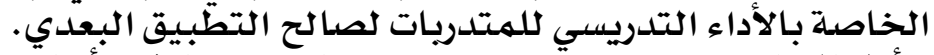

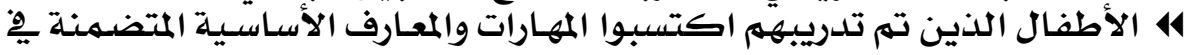

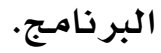

\section{0}




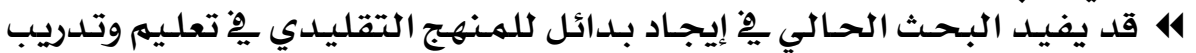

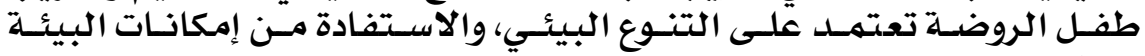

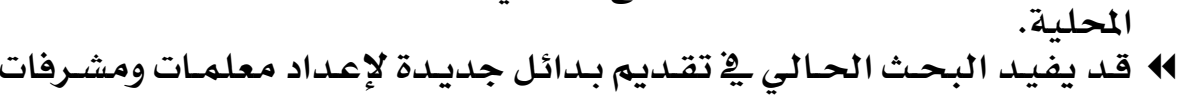

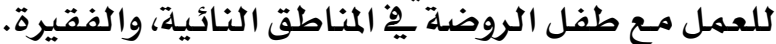

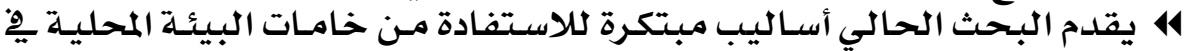

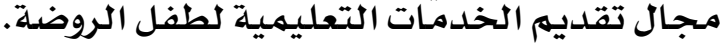

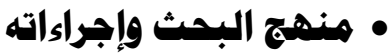

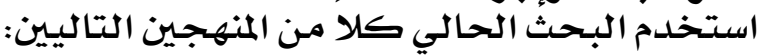

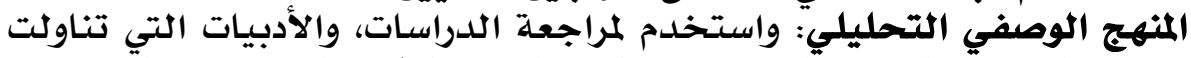

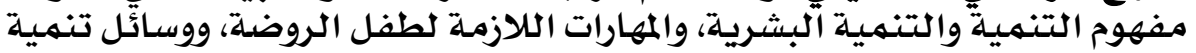

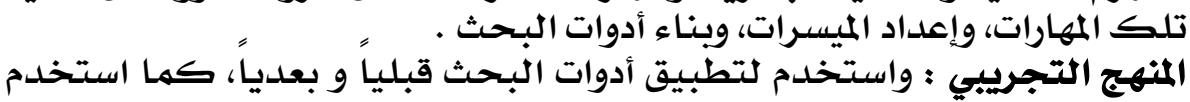

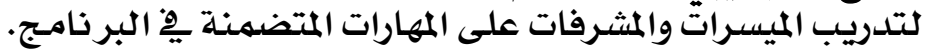

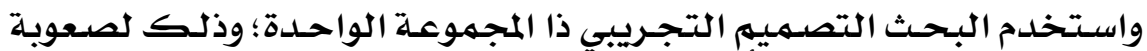

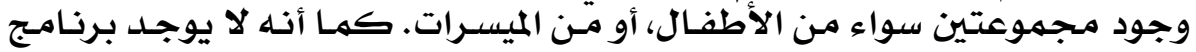

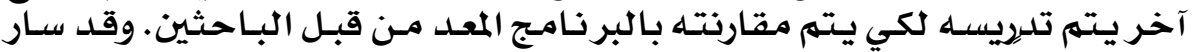
البحث وفقا للخطوات التالية:

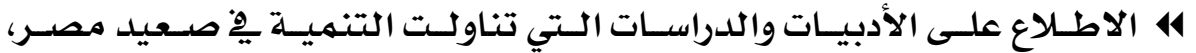

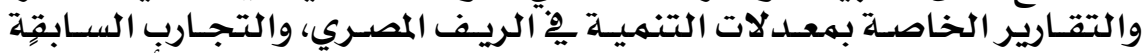

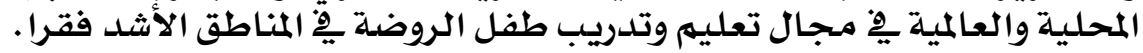

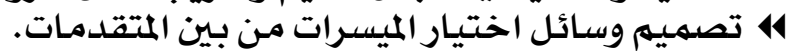

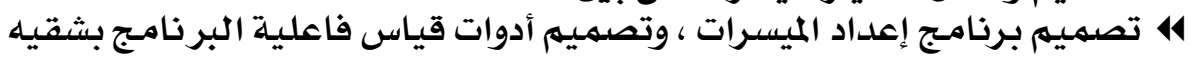
النظري والتطبيقي.

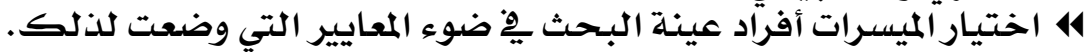

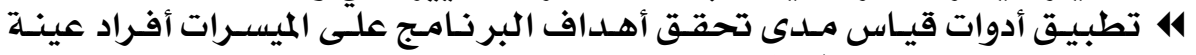

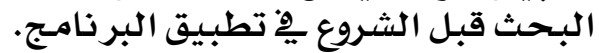

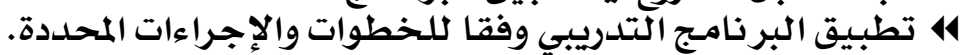

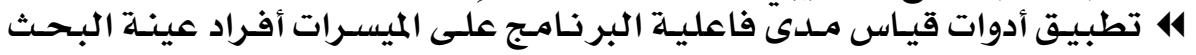

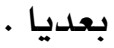
14 أستخلاص نتائج البحث، ومناقشتها وتفسيرها، ووضع التوصيات التي توصل

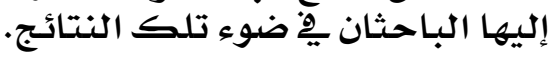

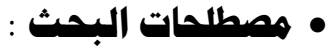

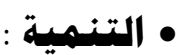

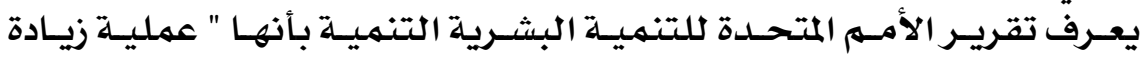

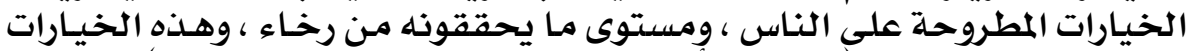

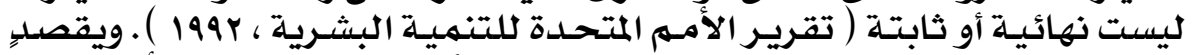

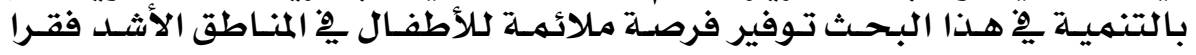

\section{7}

هوأسات عربية في ألتزبية وعiم أنففي (ASEP) 


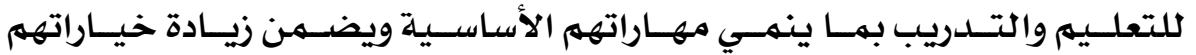

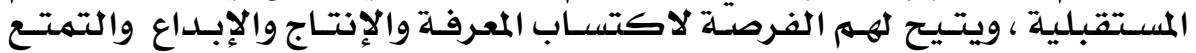

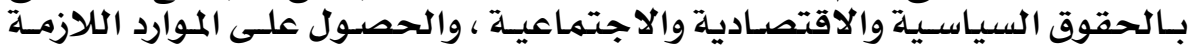
للعيش الكريه.

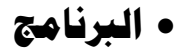

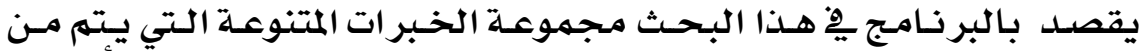

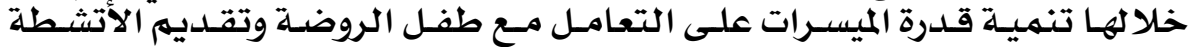

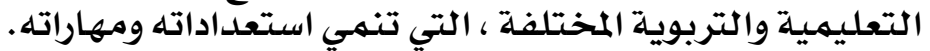

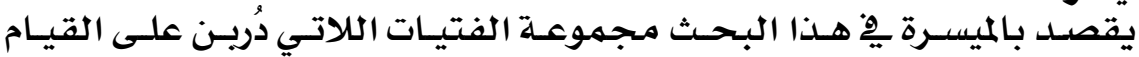

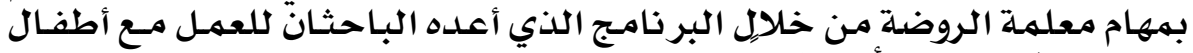

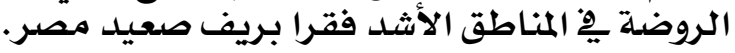

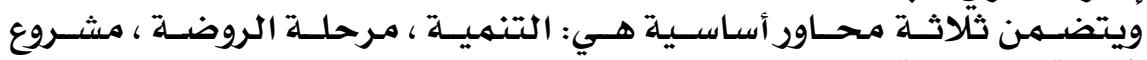

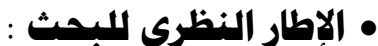
المشاركة المجتمعية.

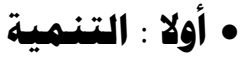

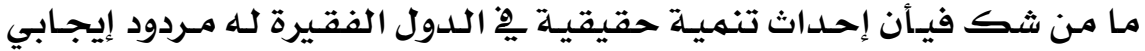

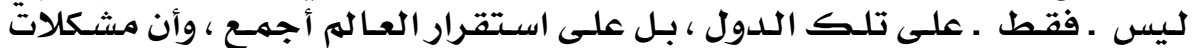

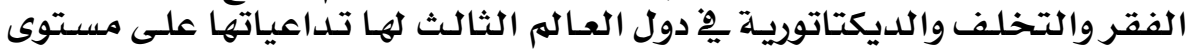

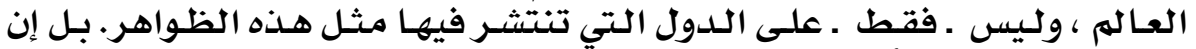

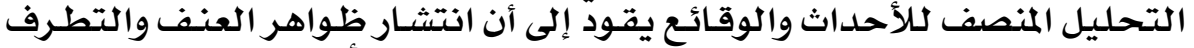

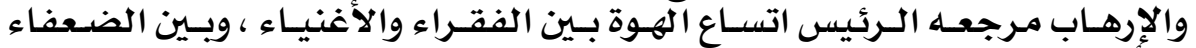

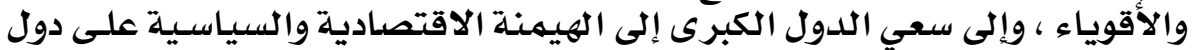

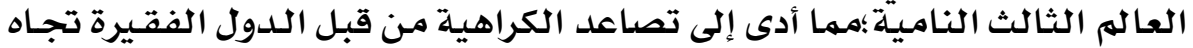

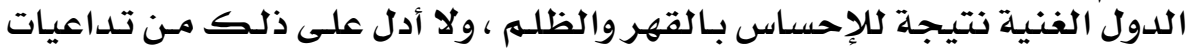

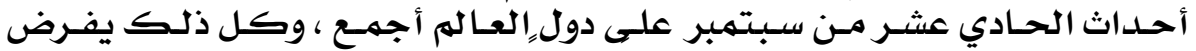

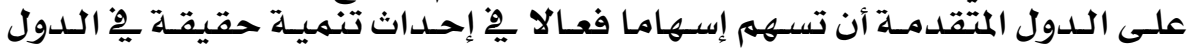

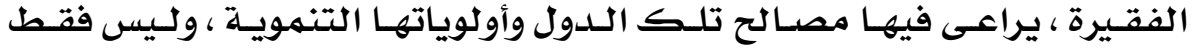

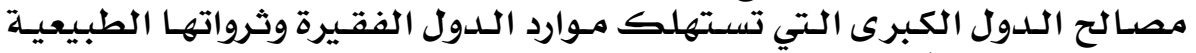

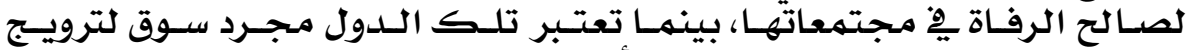

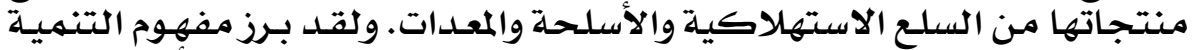

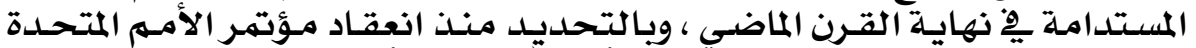

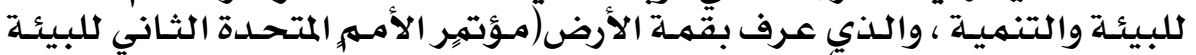

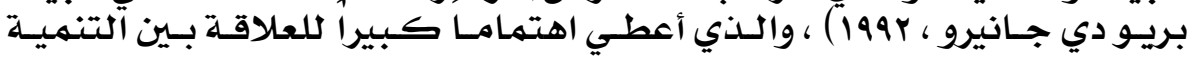

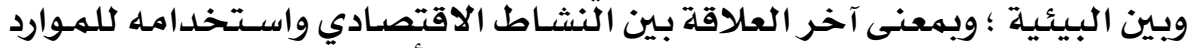

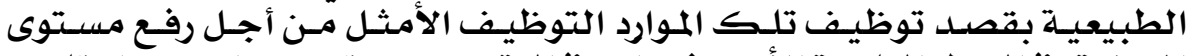

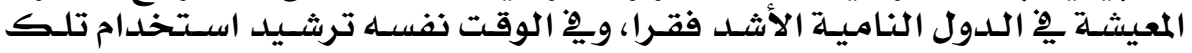

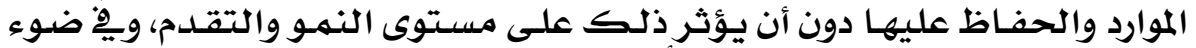

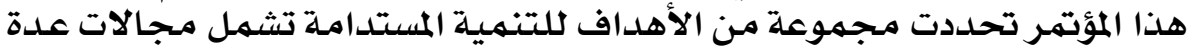




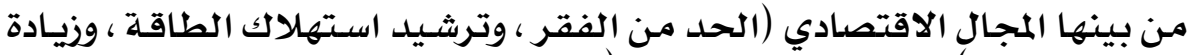

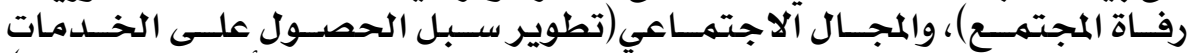

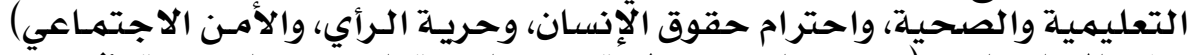

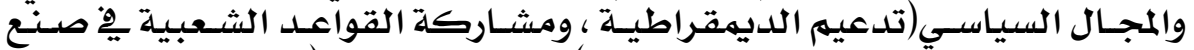

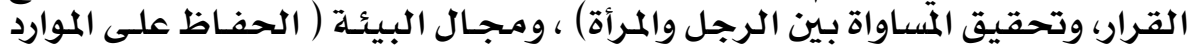

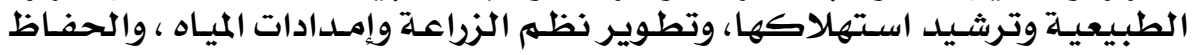

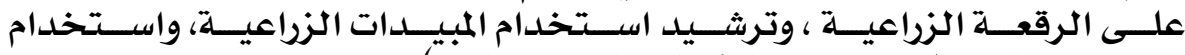

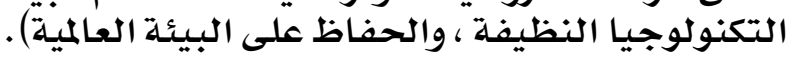

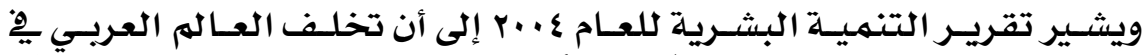

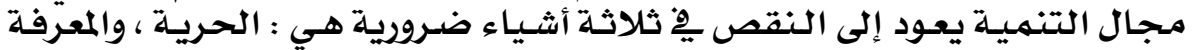

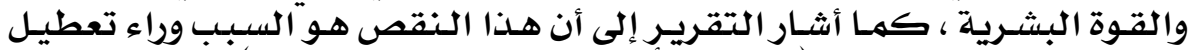

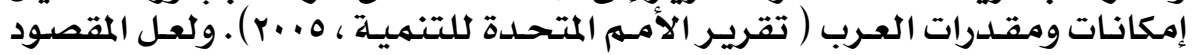

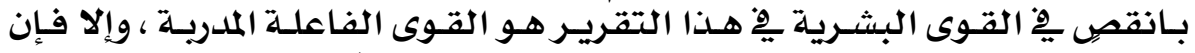

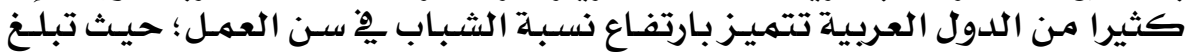

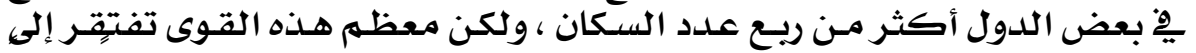

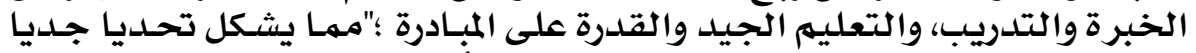

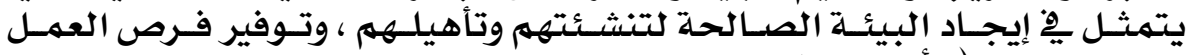

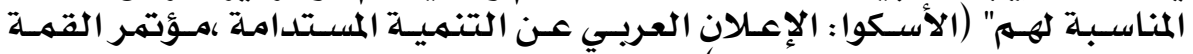

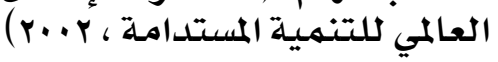

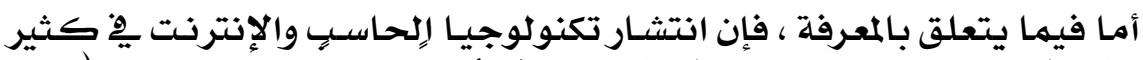

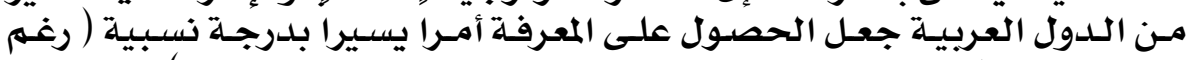

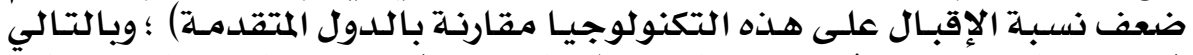

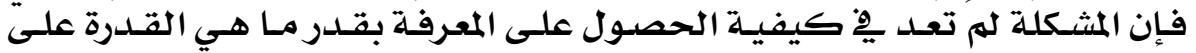

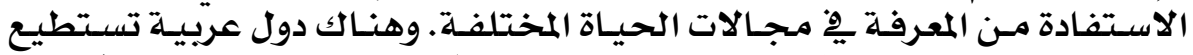

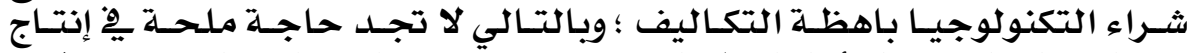

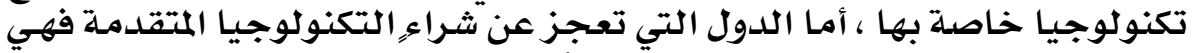

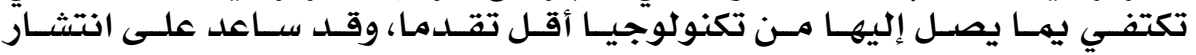

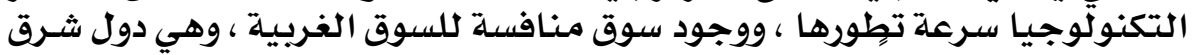

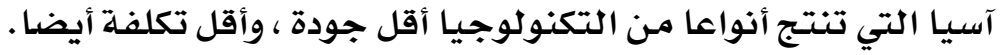

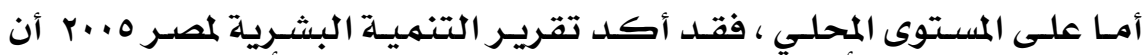

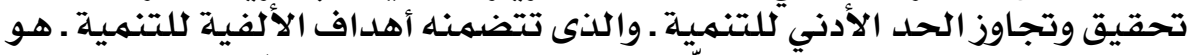

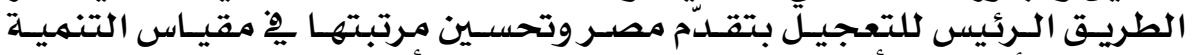

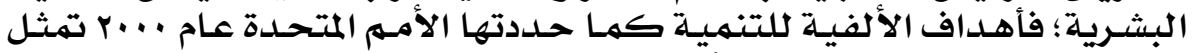

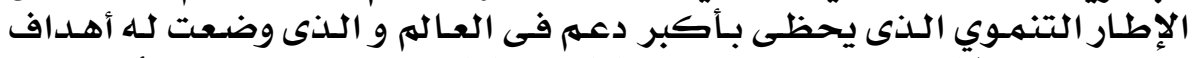

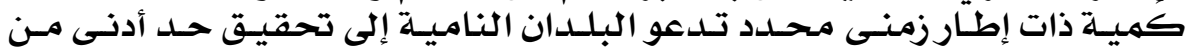

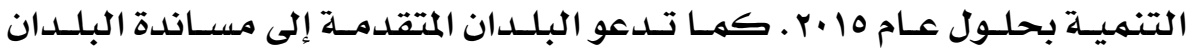

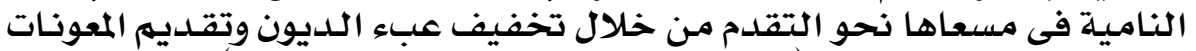

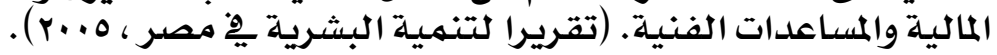




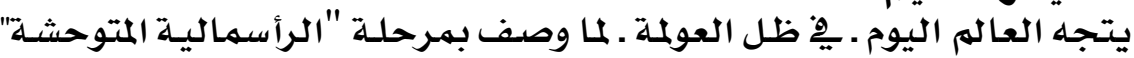

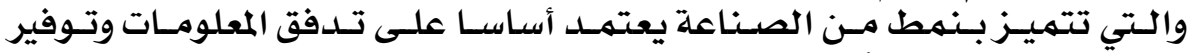

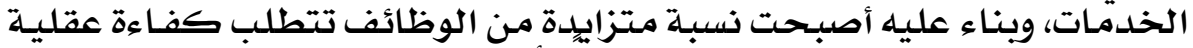

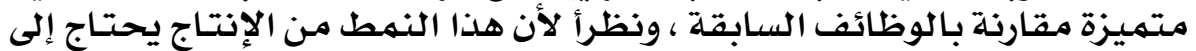

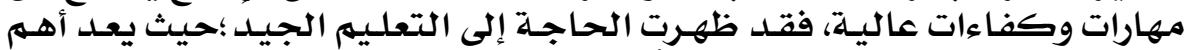

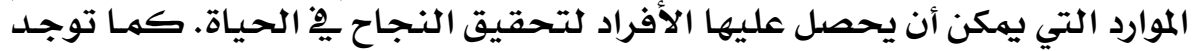

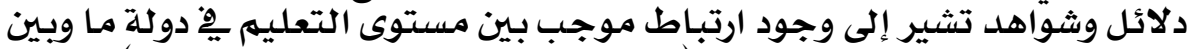

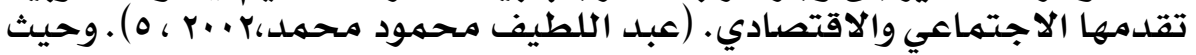

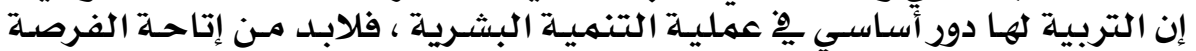

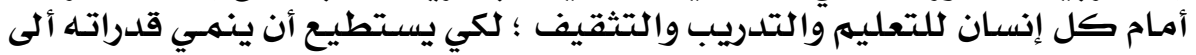

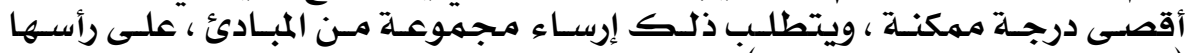

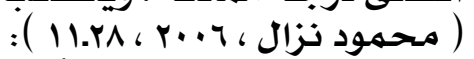

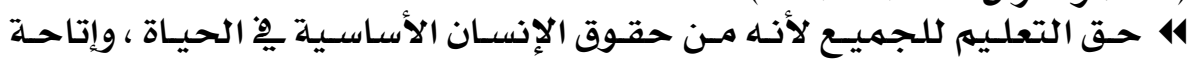

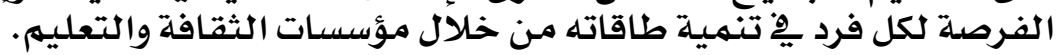

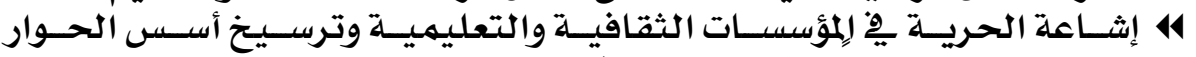

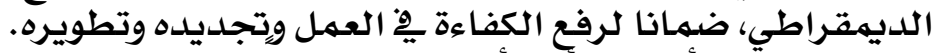

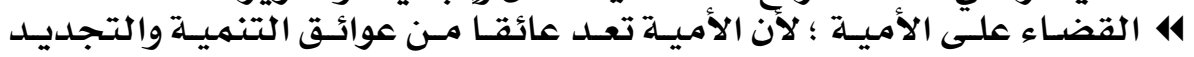

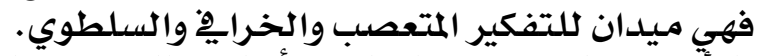

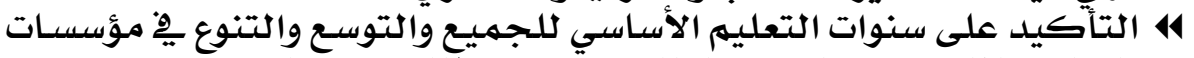

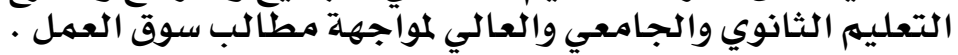

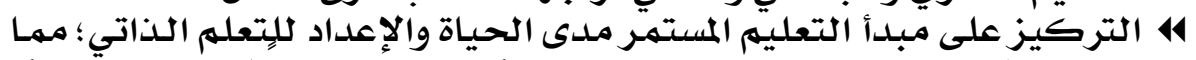

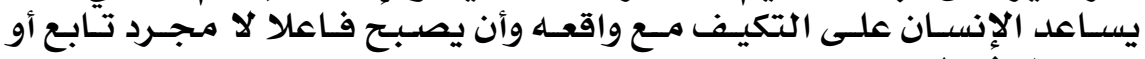
مستقبيل فقطط.

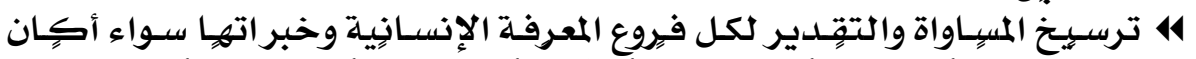

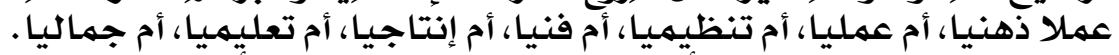

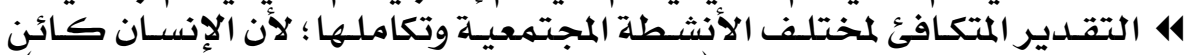

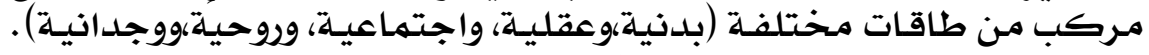

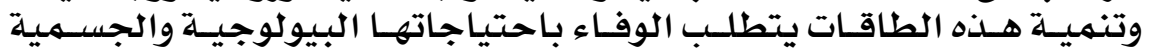

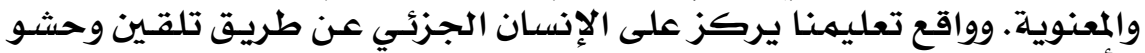

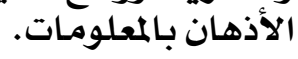

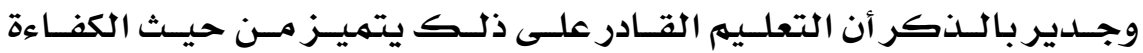

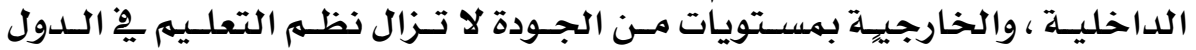

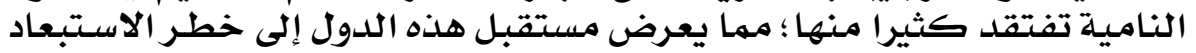

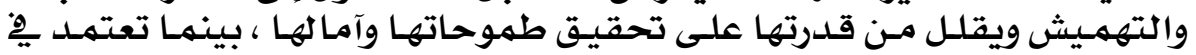

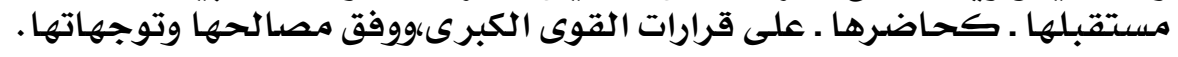

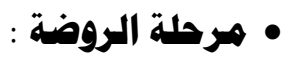

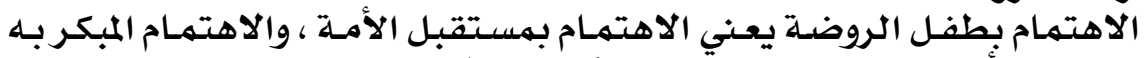

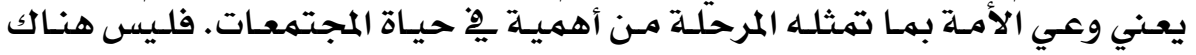

\section{9}




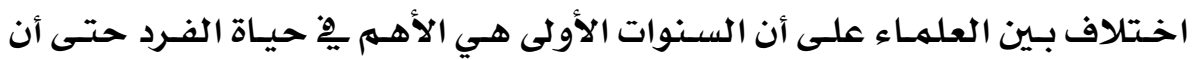

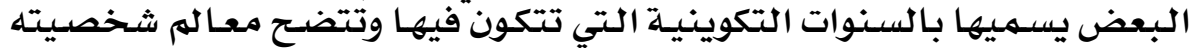

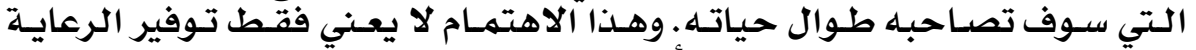

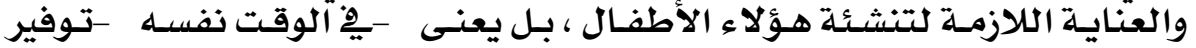

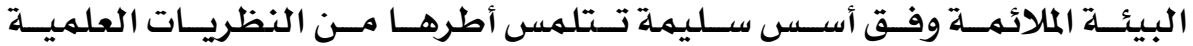

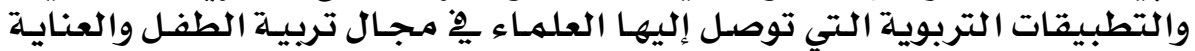

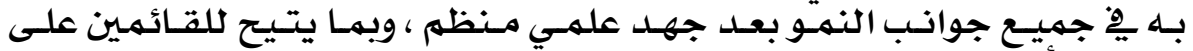

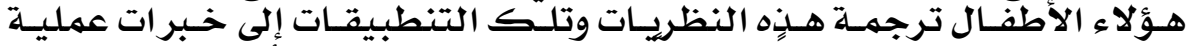

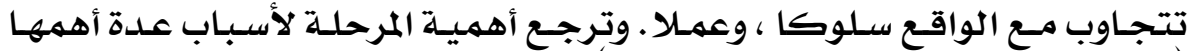

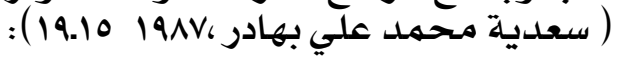

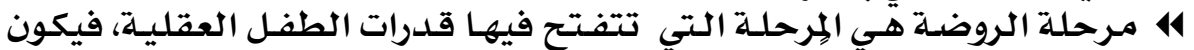

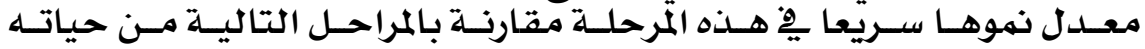

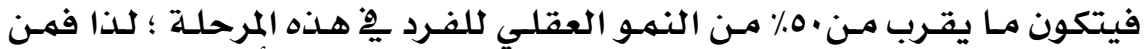

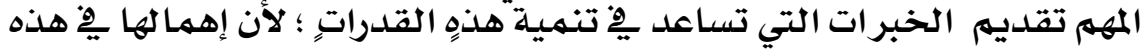

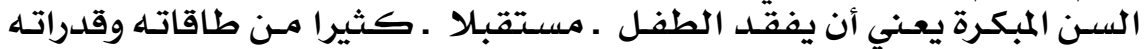

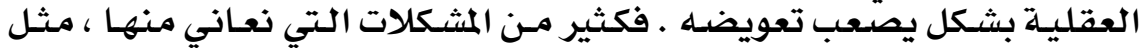

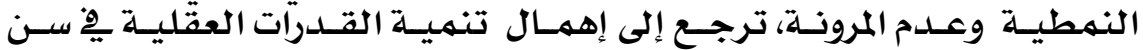
مبكرة.

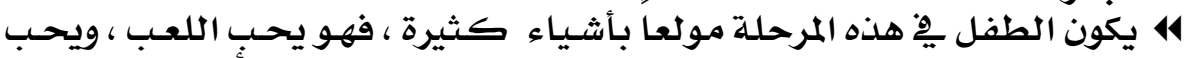

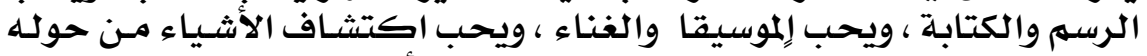

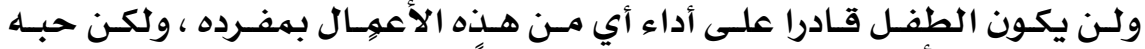

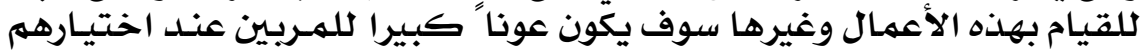

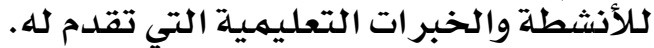

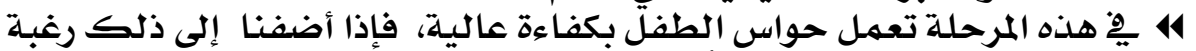

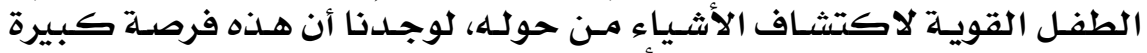

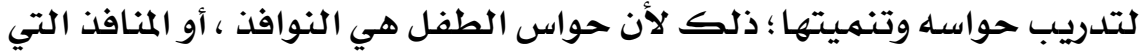

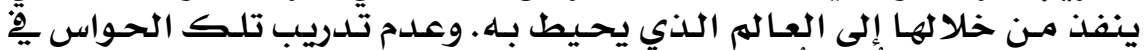

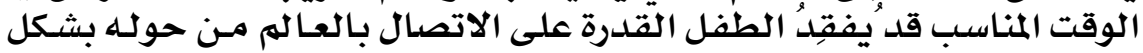

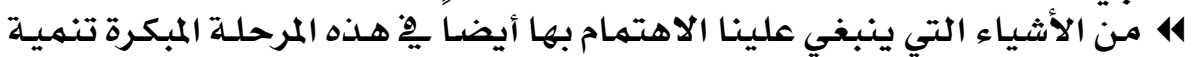

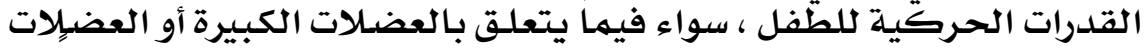

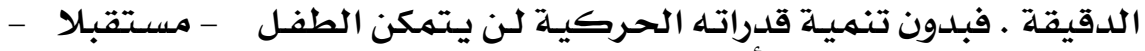

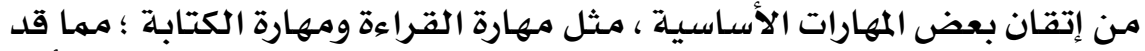

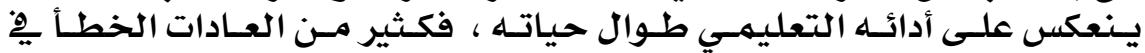

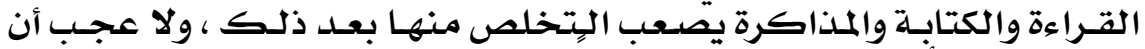

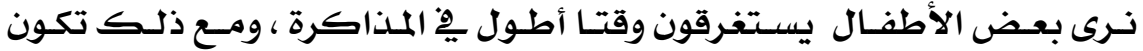

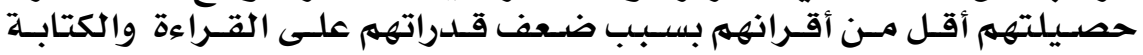
والمذاكرة.

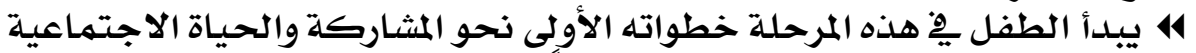

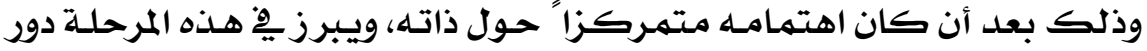




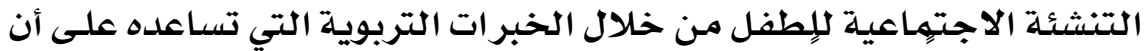

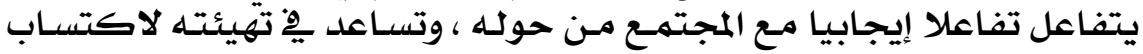

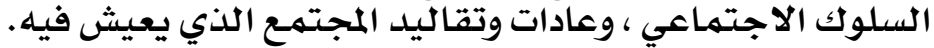

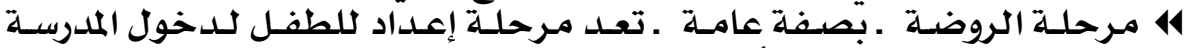

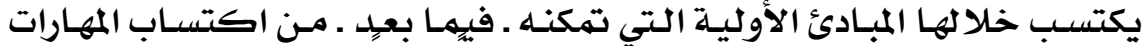

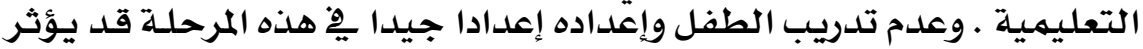

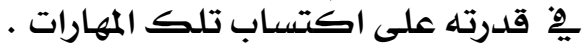

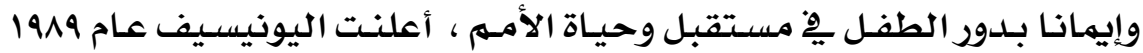

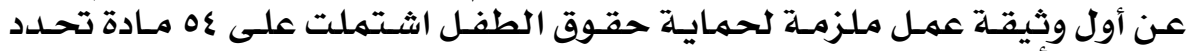

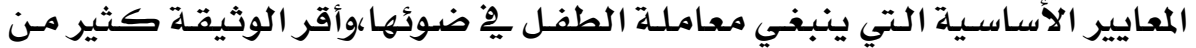

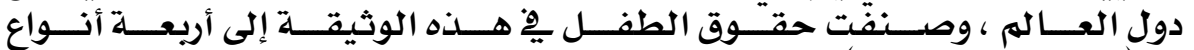

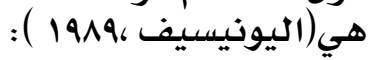

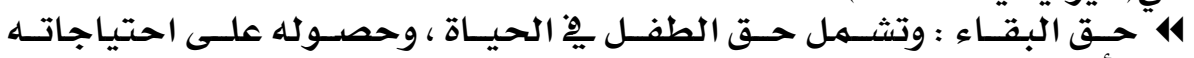

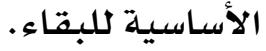

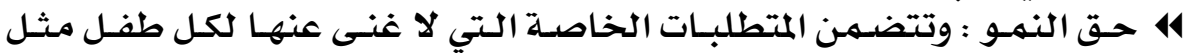

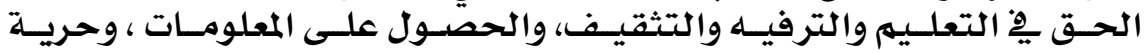

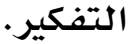

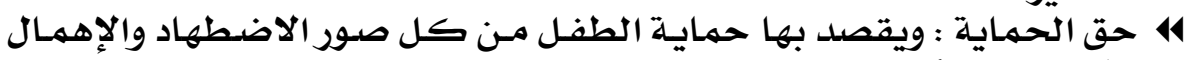
والاستغلال ، أو التعذيب ، والقيل ، والعمالة المبكرة.

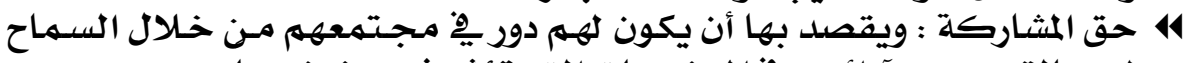

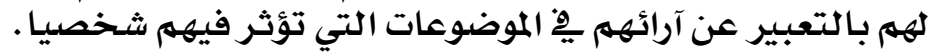

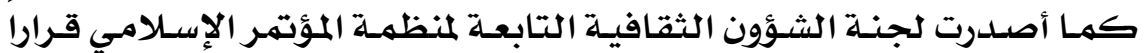

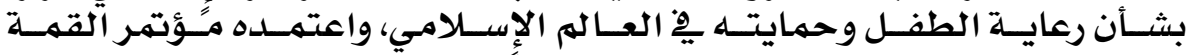

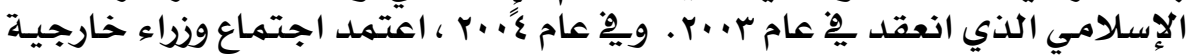

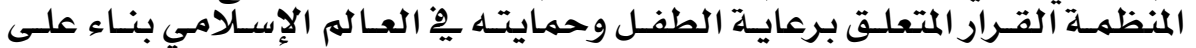

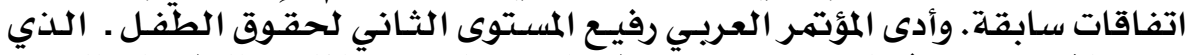

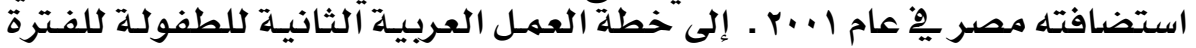

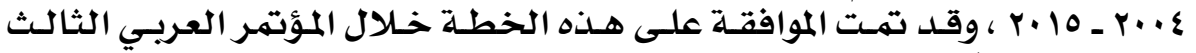

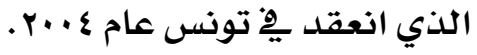

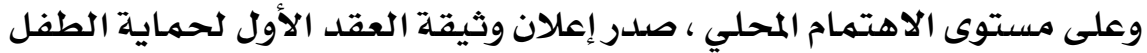

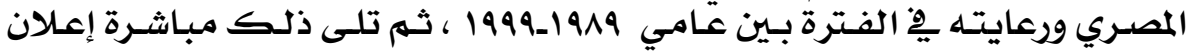

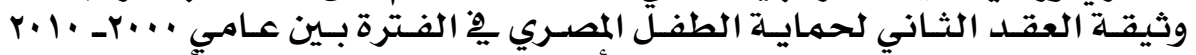

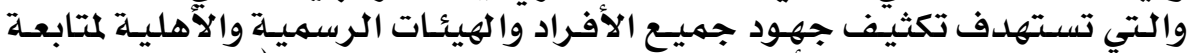

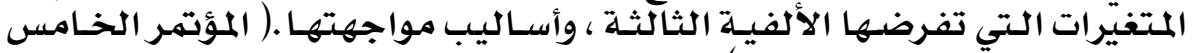

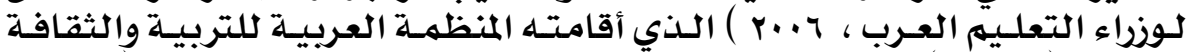

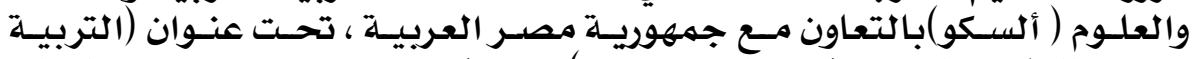

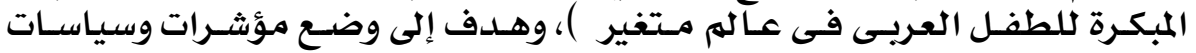

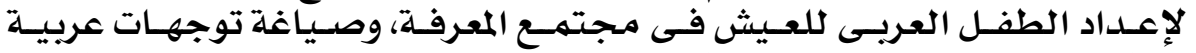

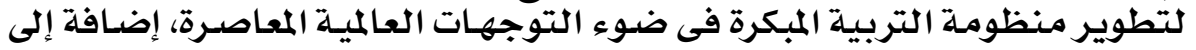




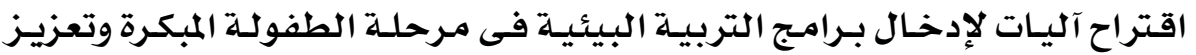

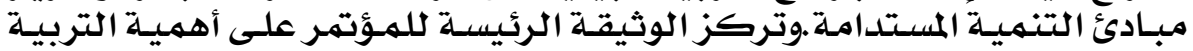

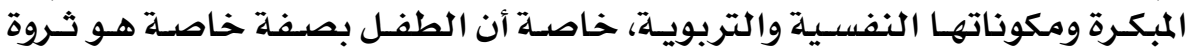

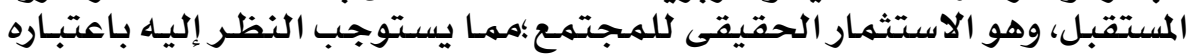

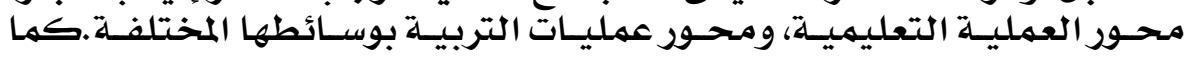

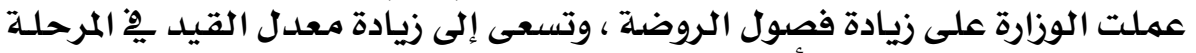

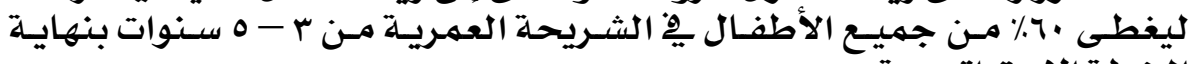
الخطة الاستر اتيجية.

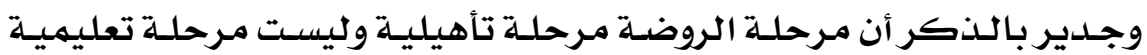

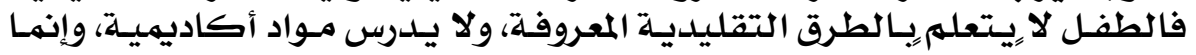

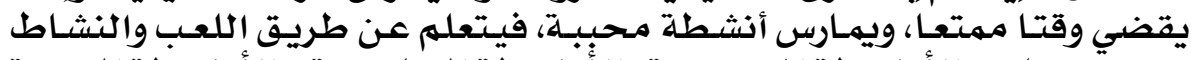

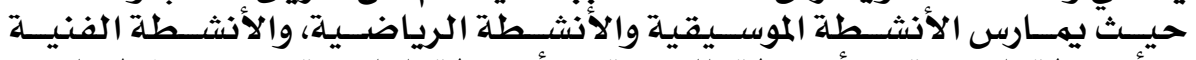

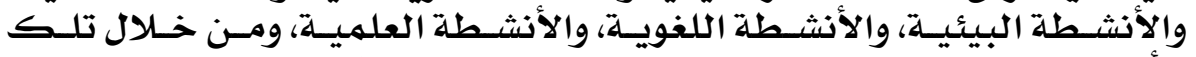

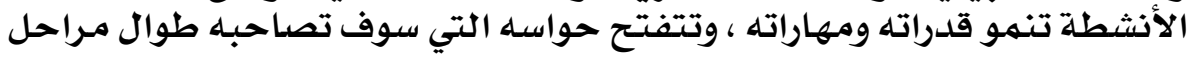
التعليه.

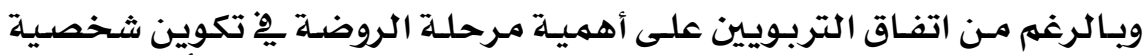

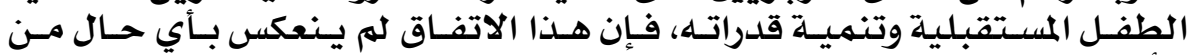

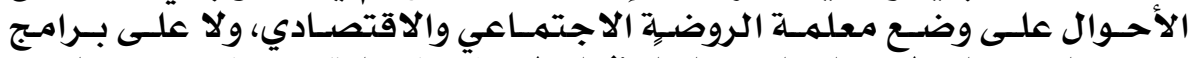

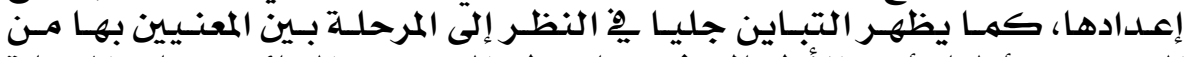

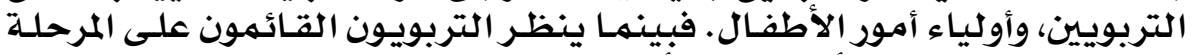

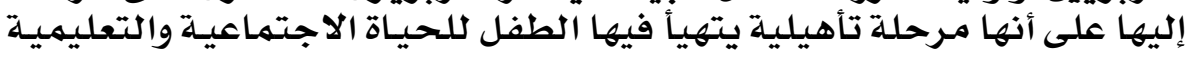

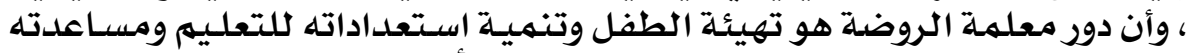

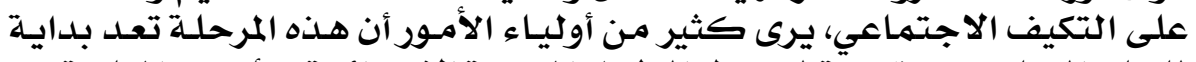

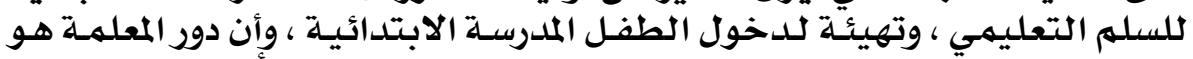

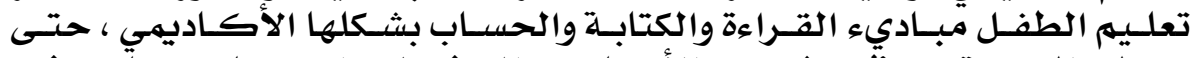

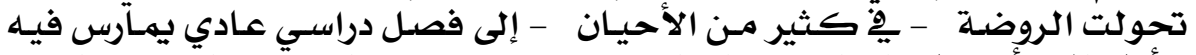

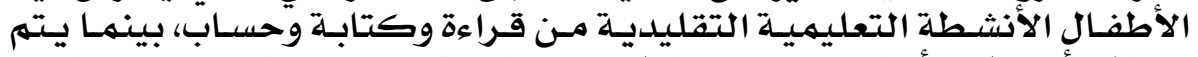

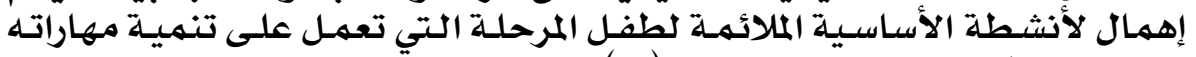

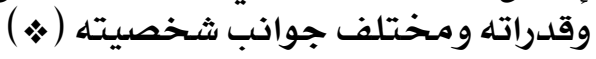

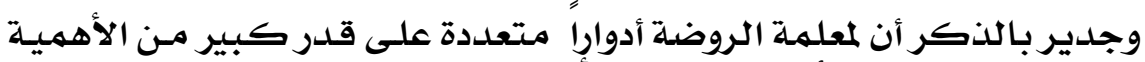

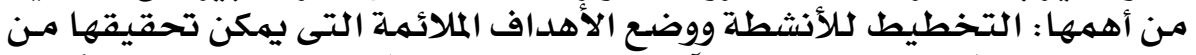

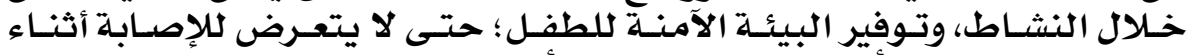

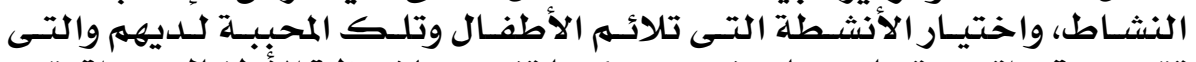

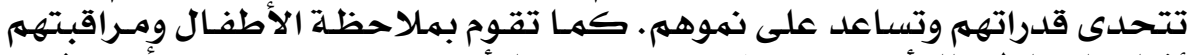

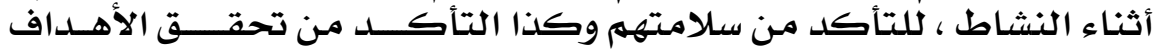

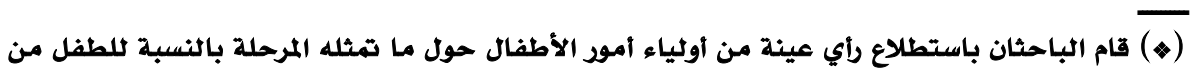

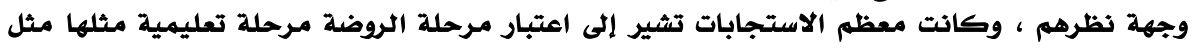

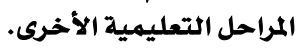




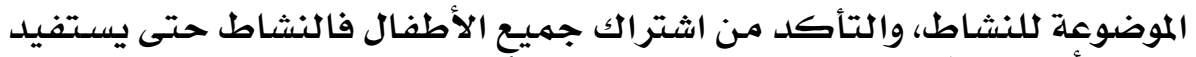

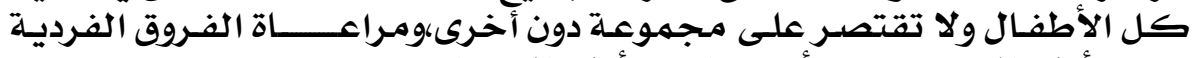

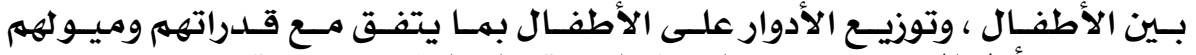

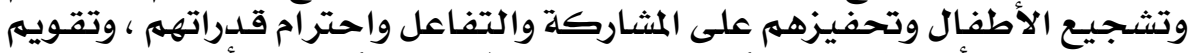

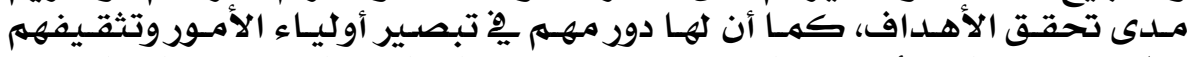

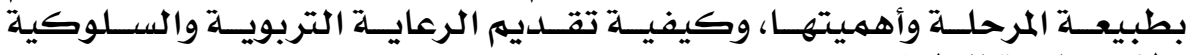
والاجتماعية للطفل.

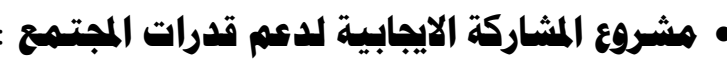

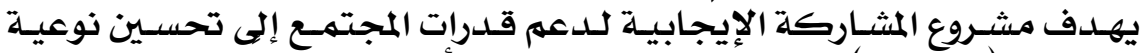

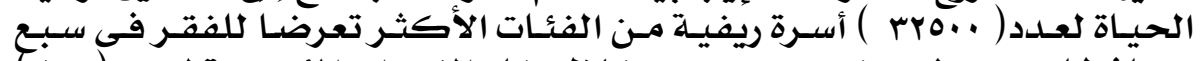

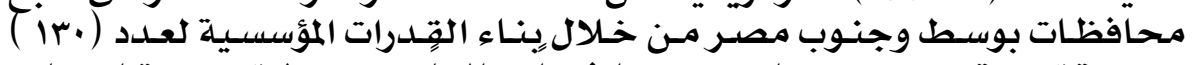

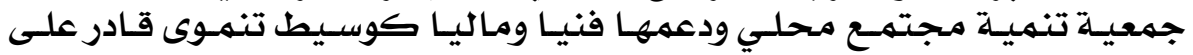

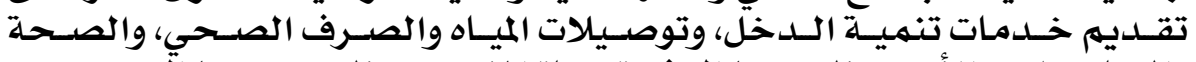

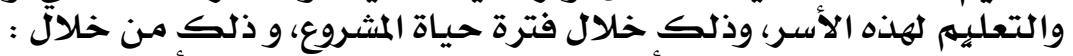

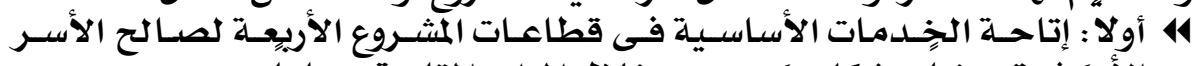

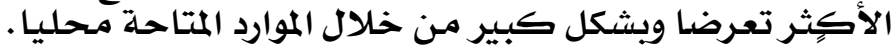

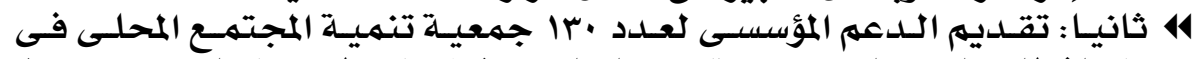

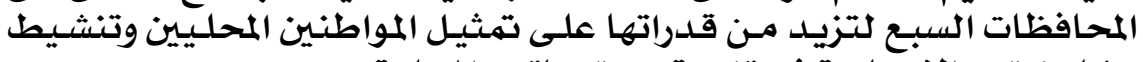

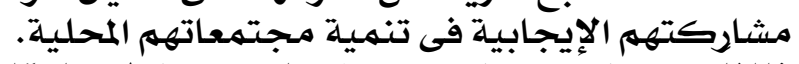

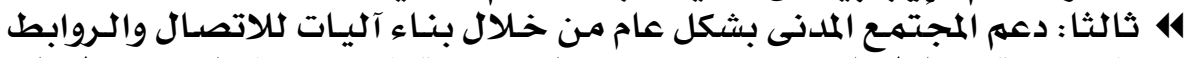

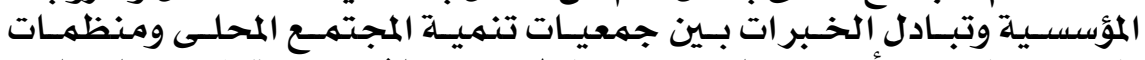

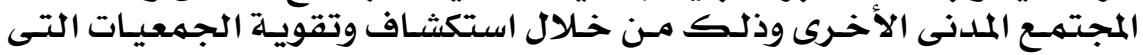

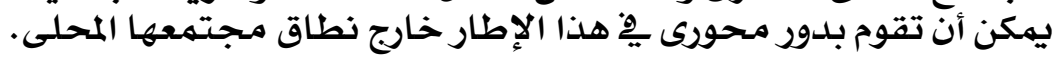

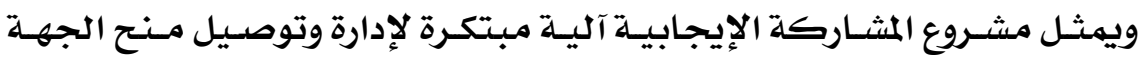

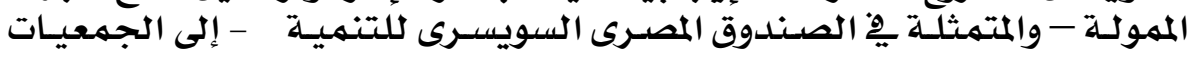

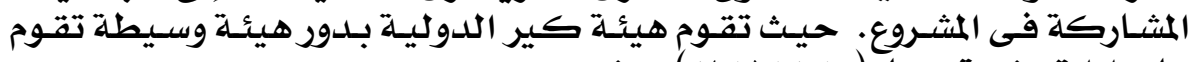

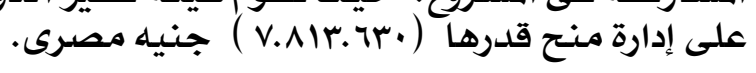

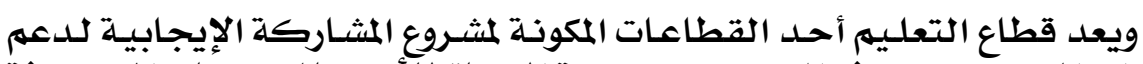

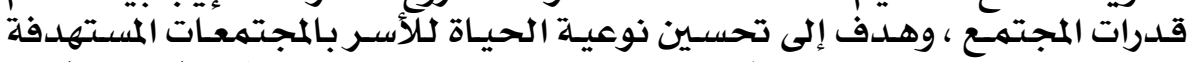

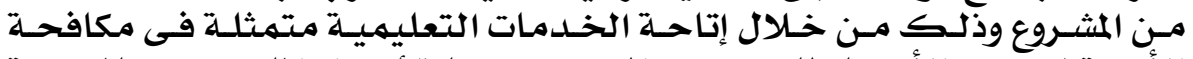

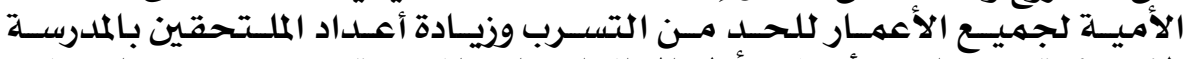

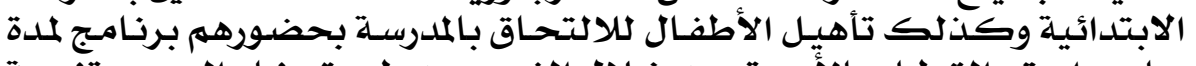

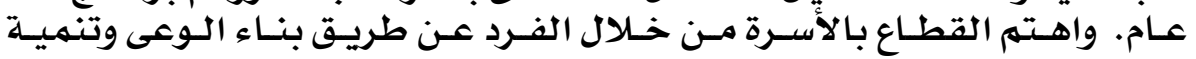

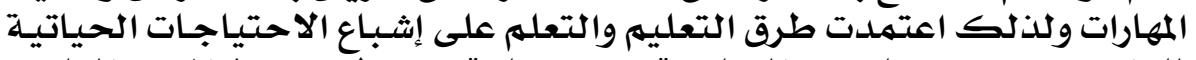

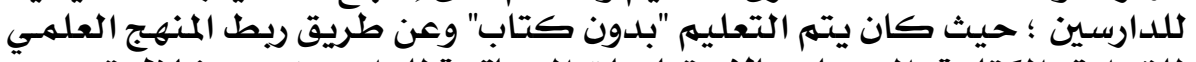

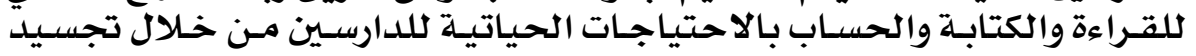

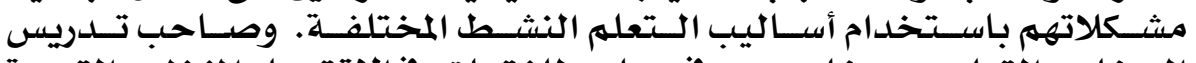

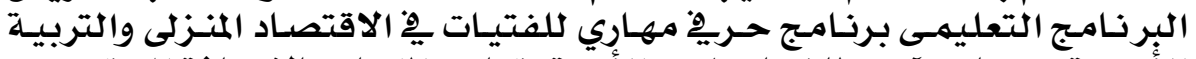

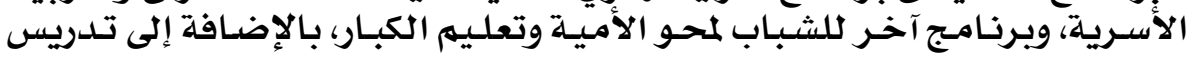

\section{$17 \%$}




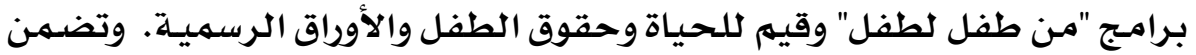

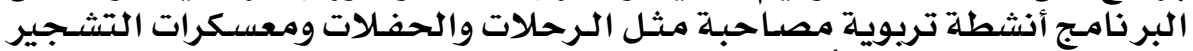

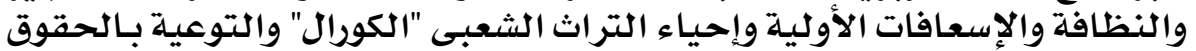

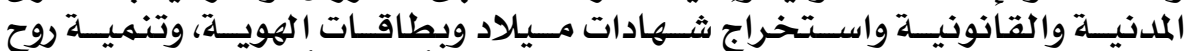

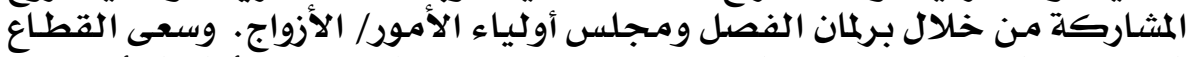

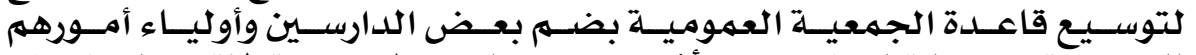

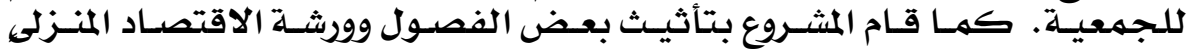

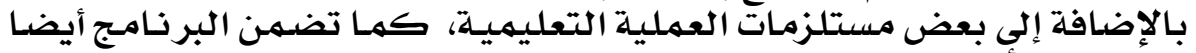

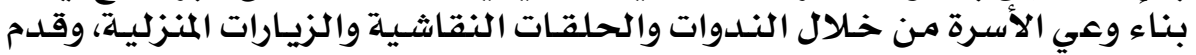

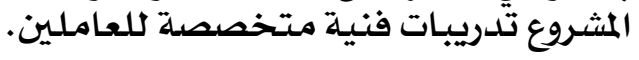

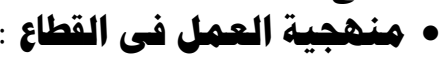

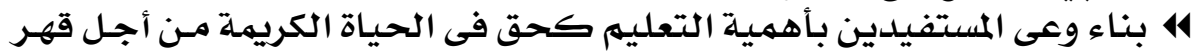
الفقر.

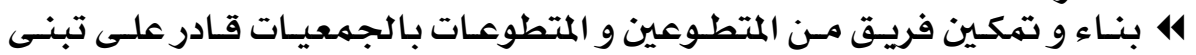

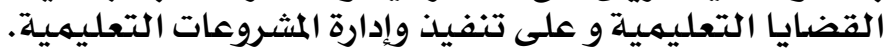

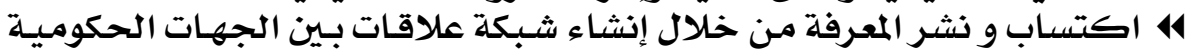

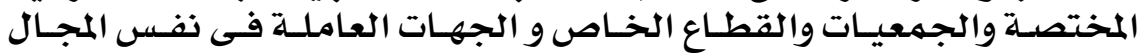

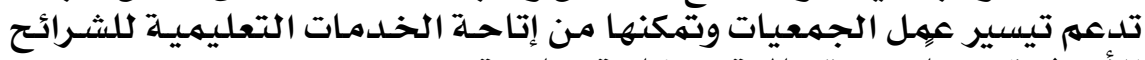

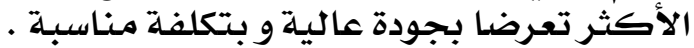

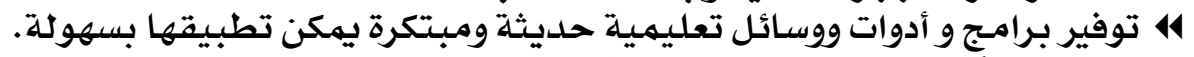

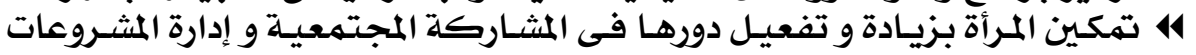

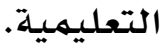

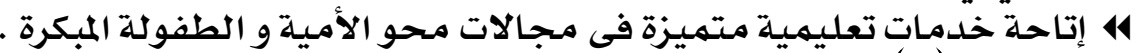

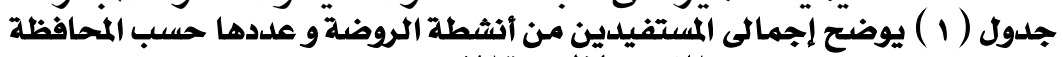

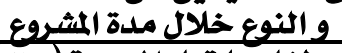

\begin{tabular}{|c|c|c|c|c|}
\hline \multirow[t]{2}{*}{ فصول تثقيف الأمهات (r) } & \multicolumn{3}{|c|}{ مركز إعداد طفل ما قبل المدرسية (r. (r) } & \multirow{2}{*}{ المحافظات } \\
\hline & محموع & إناث & ذ ذكور & \\
\hline A. & IA. & Av & ar & 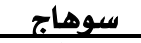 \\
\hline $\mathrm{VA}$ & va & $\sum 9$ & $r r$ & قنا \\
\hline$r \ldots$ & $\varepsilon \cdots$ & $r \ldots$ & $r \ldots$ & أسوان \\
\hline
\end{tabular}

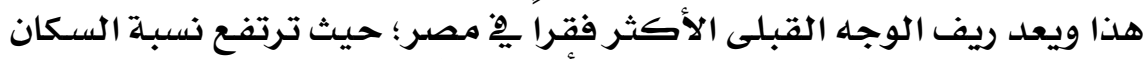

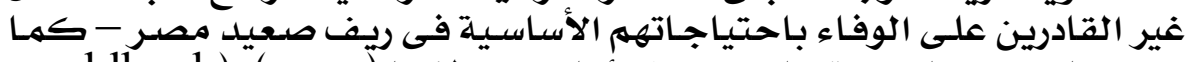

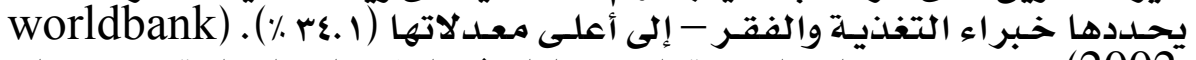

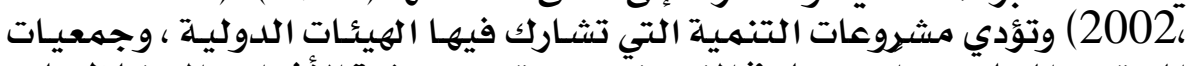

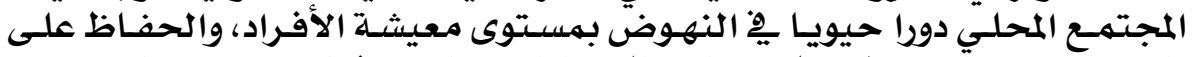

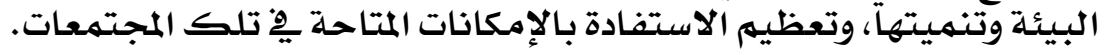

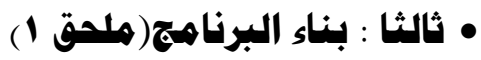

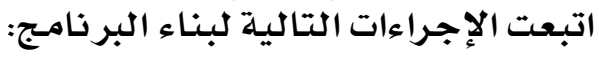

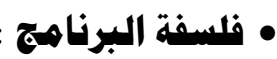
يقوم البرنامـج على الأسس التالية:

\section{$17 \varepsilon$}




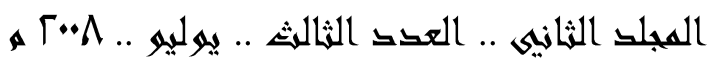

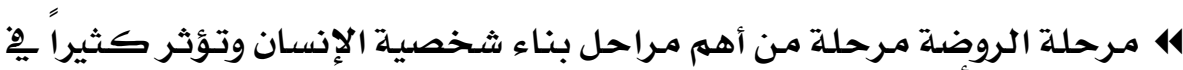

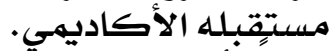

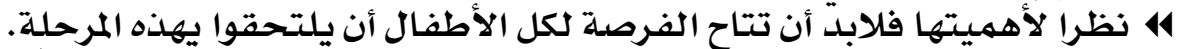

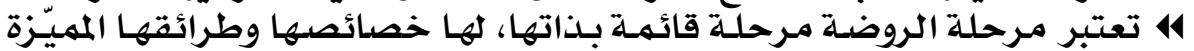

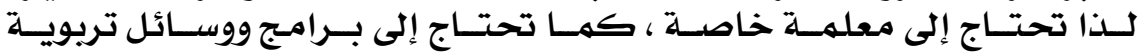
وتجهيزات ملائممة.

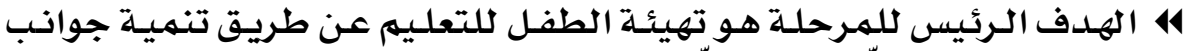

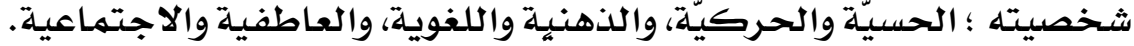

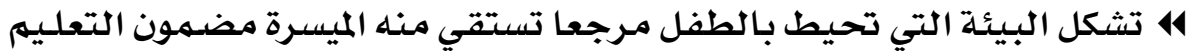

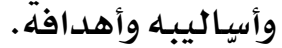

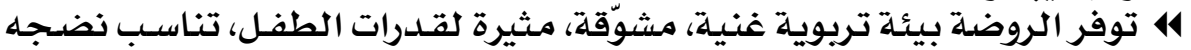

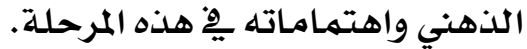

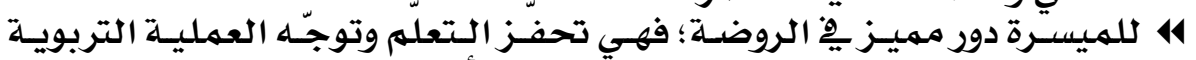

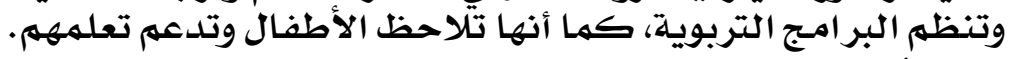

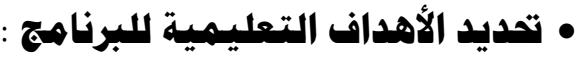

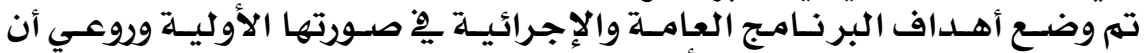

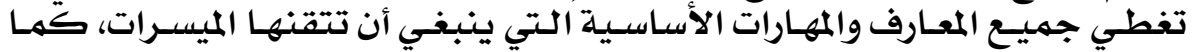

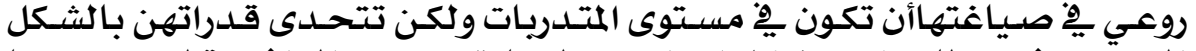

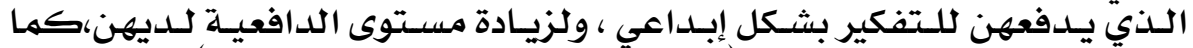

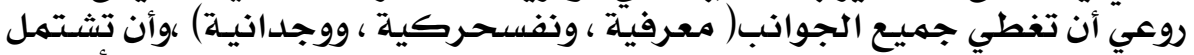

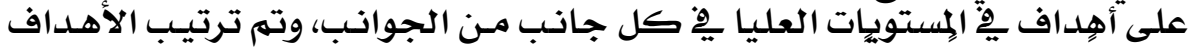

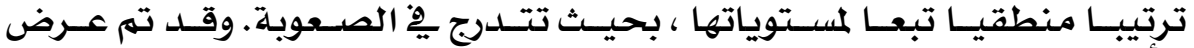

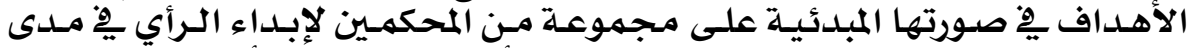

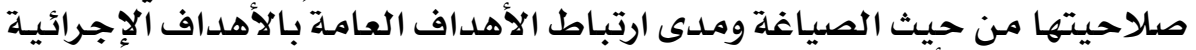

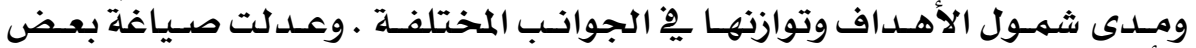

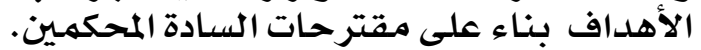

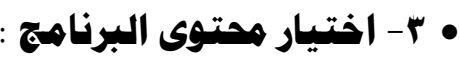

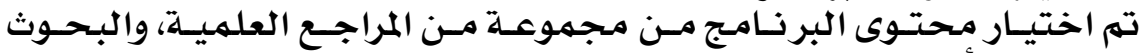

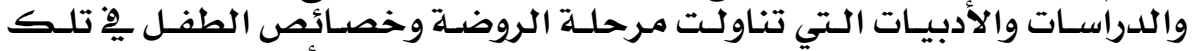

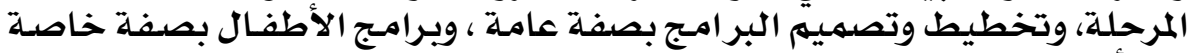

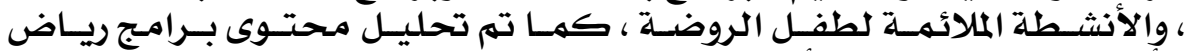

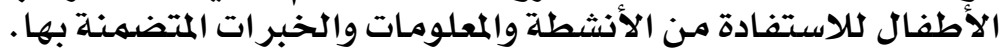

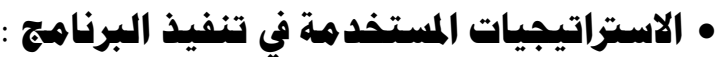

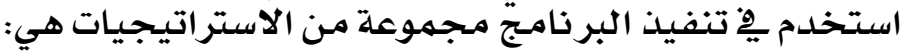

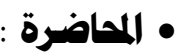

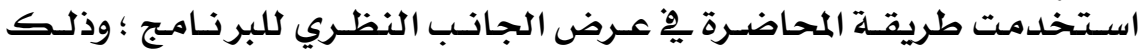

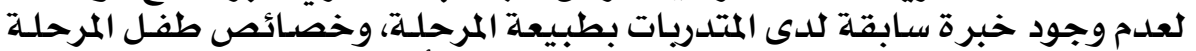

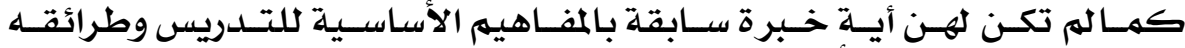

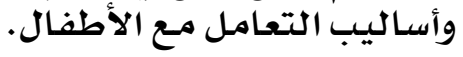

\section{0}

دوأسات عربية في الثزبية وعائم النفس (ASEP) 


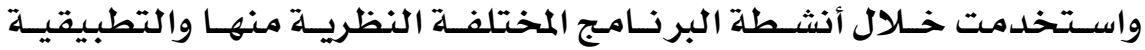

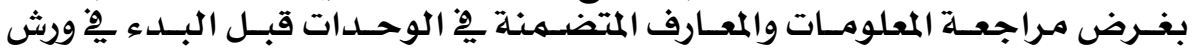

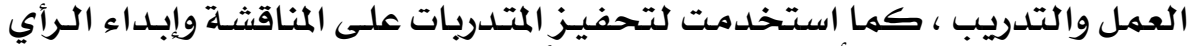

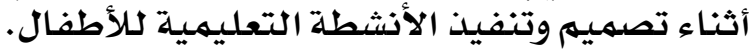

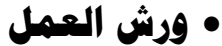

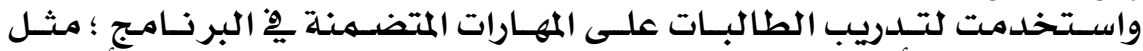

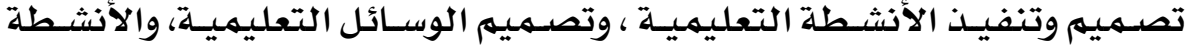

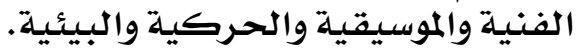

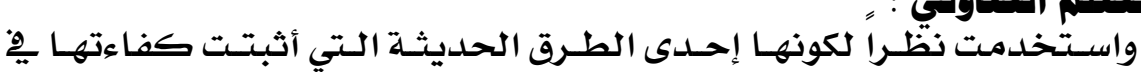

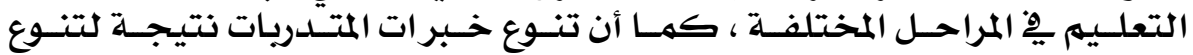

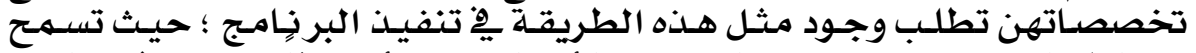

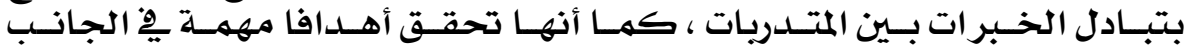

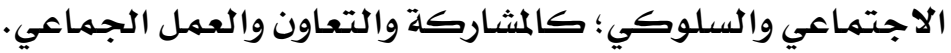
• الدراها الإبداعية والية

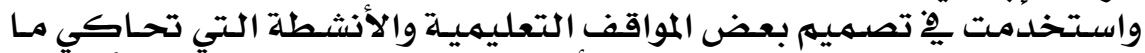

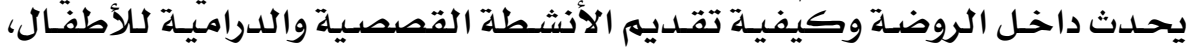

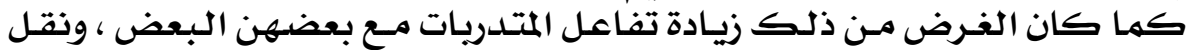

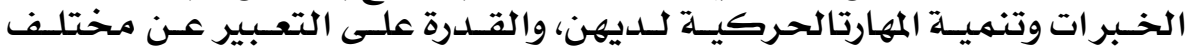

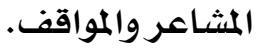

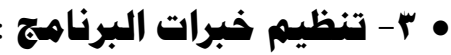

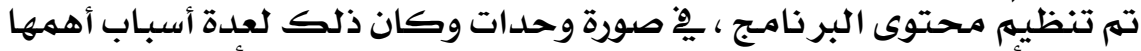

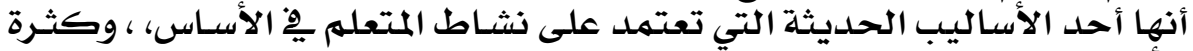

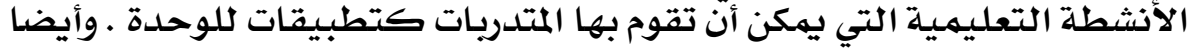

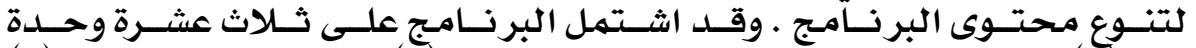

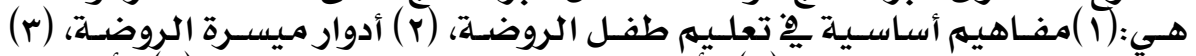

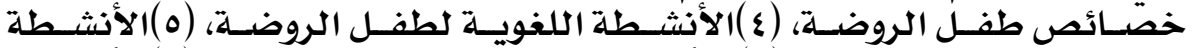

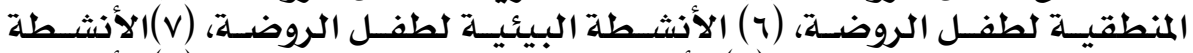

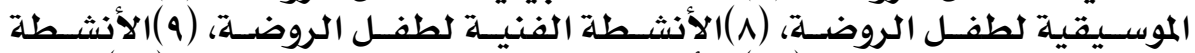

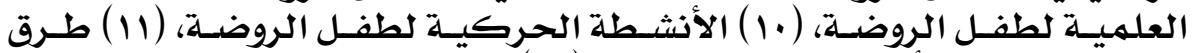

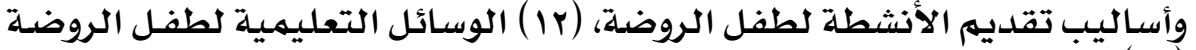

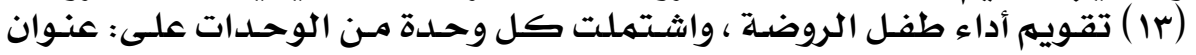

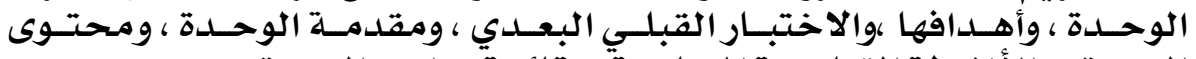

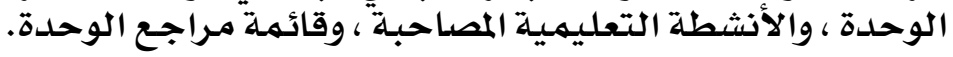

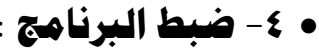

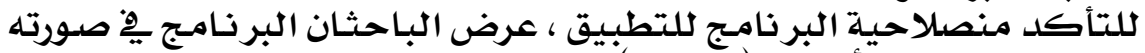

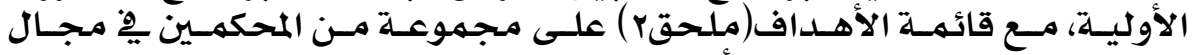

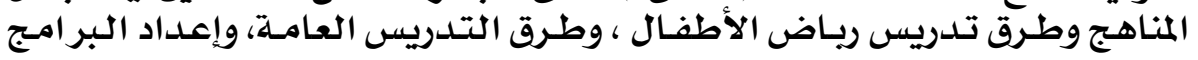

\section{7}




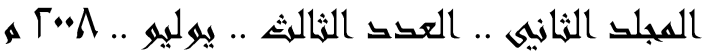

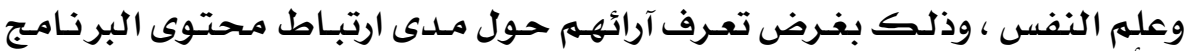

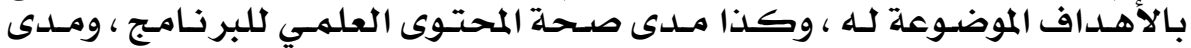

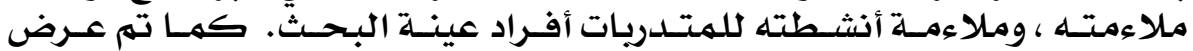

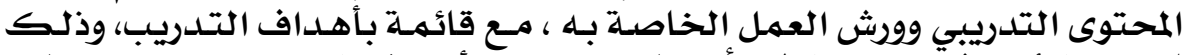

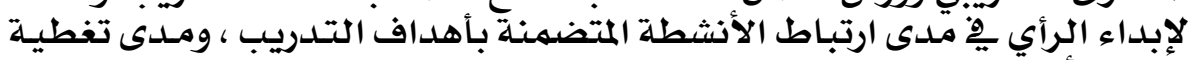

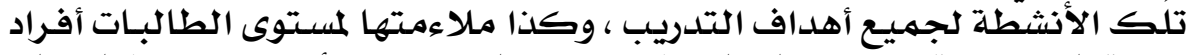

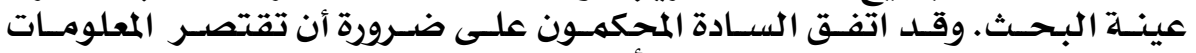

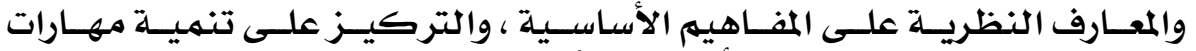

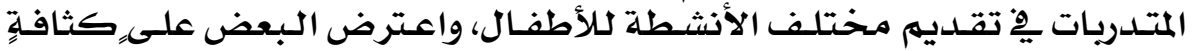

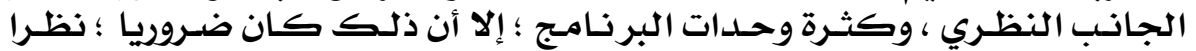

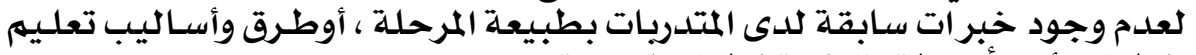

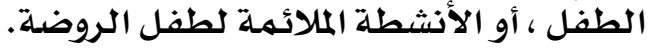

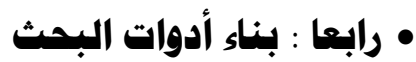

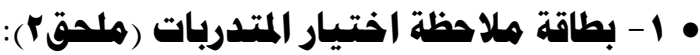

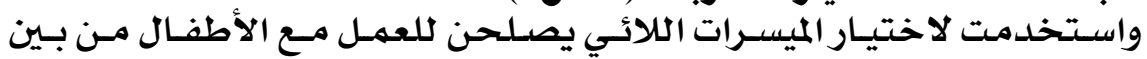

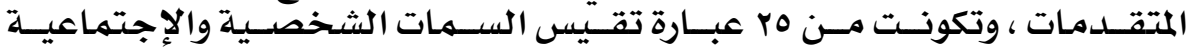

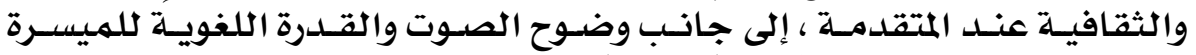

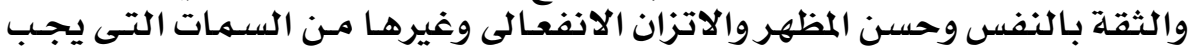

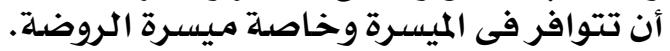

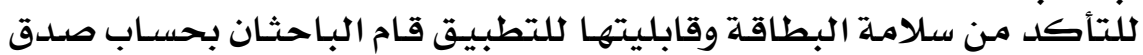

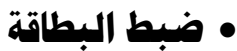

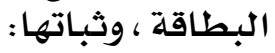

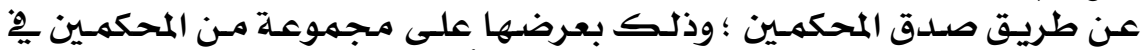

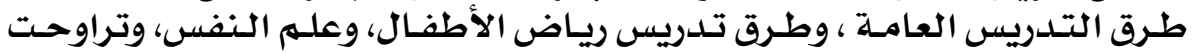

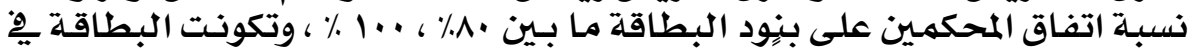

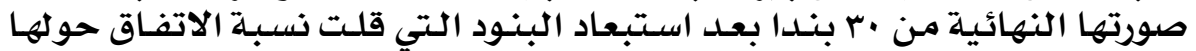

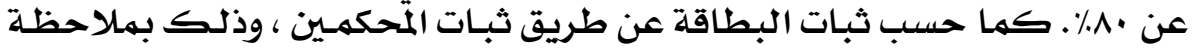

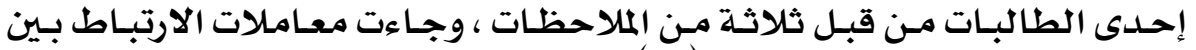

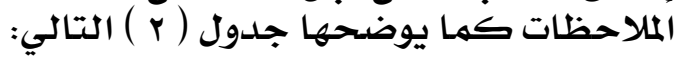

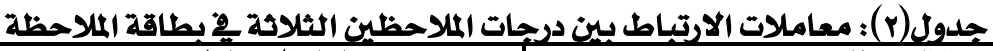

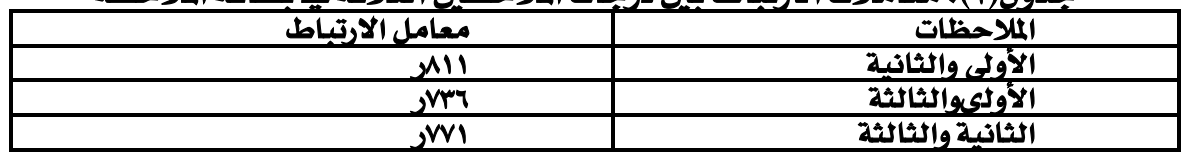

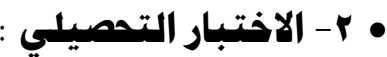

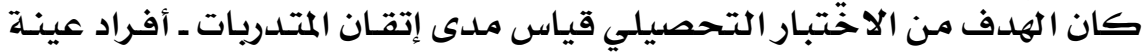

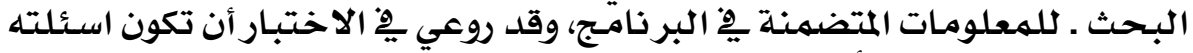

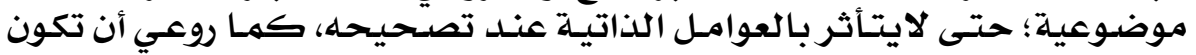

\section{$17 \mathrm{~V}$}




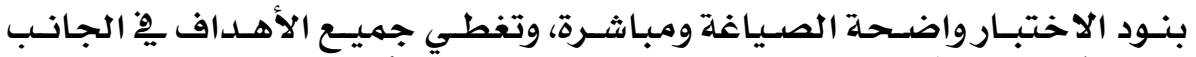

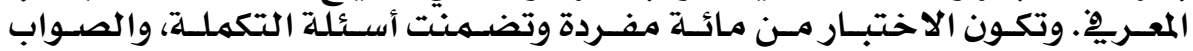

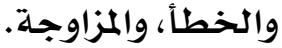

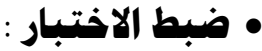

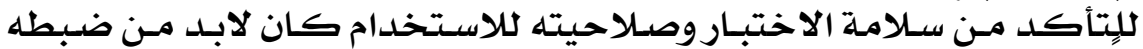

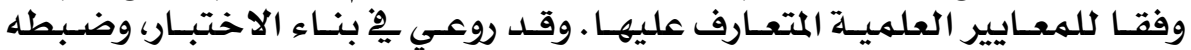

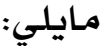

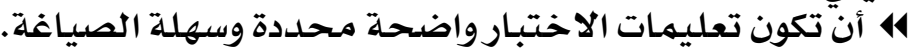

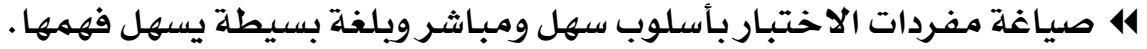

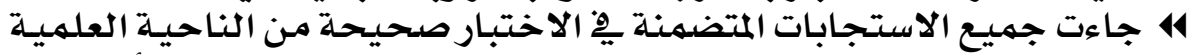

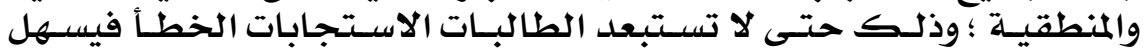
عليهن الوصول إلى الاستجابـة الابة المطلوبية.

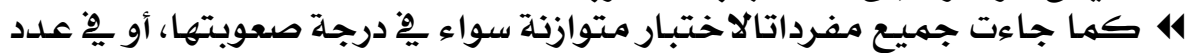

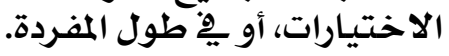

وبعد إعداد الاختبار ِِِ صورته الأولية، تم ضبطه وفق الإجراءات التالية:

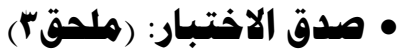

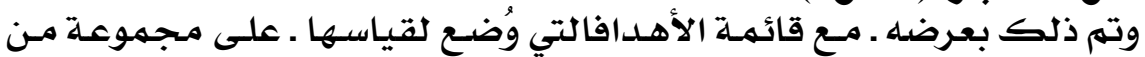

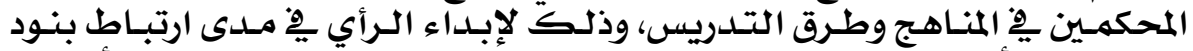

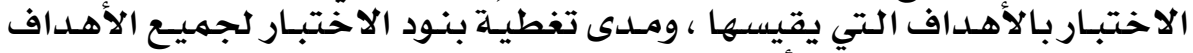

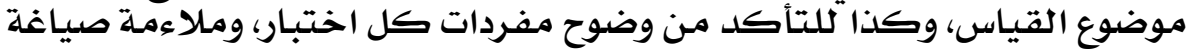

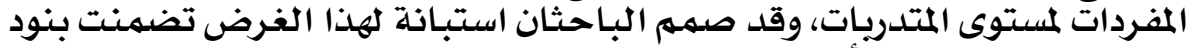

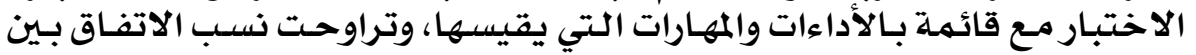

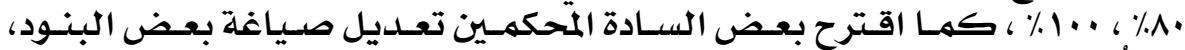

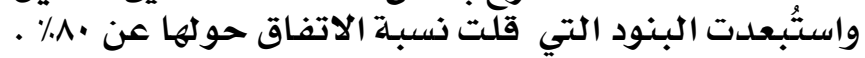

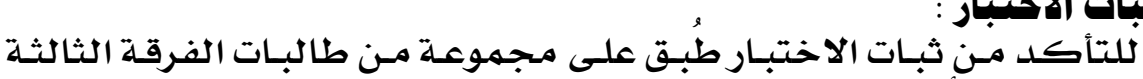

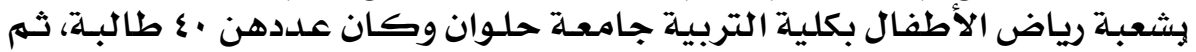

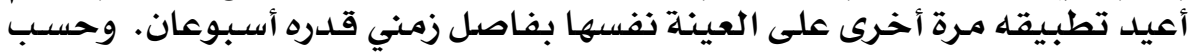

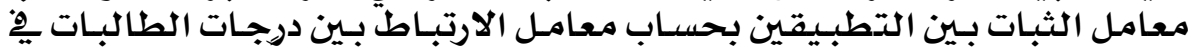

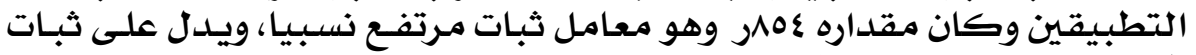
الاختبار وصلاحيته ولتهان مقلتطبيق.

\section{• تقدير درجات الاختبار :}

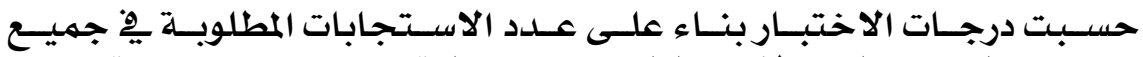

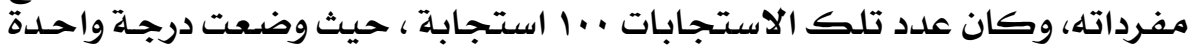

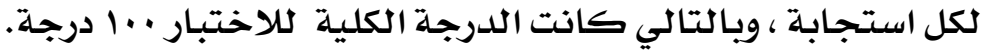

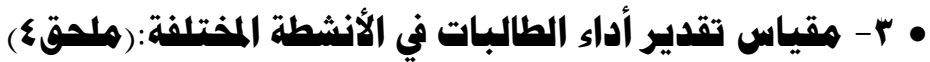

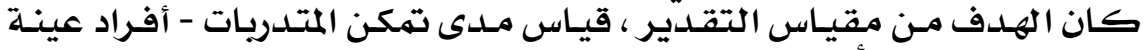

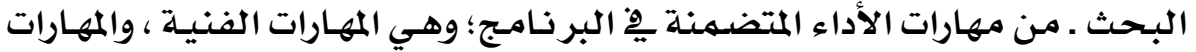

\section{1}




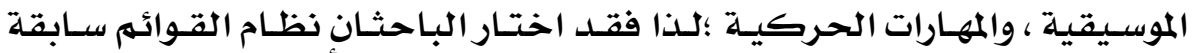

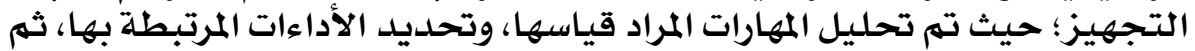

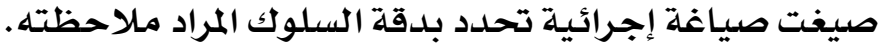

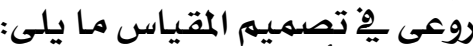

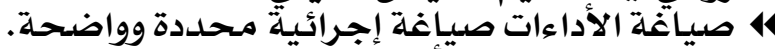

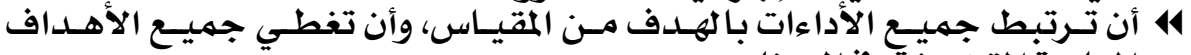

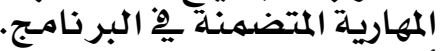

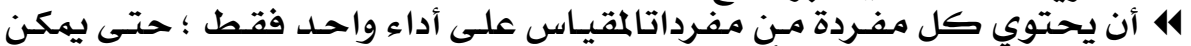

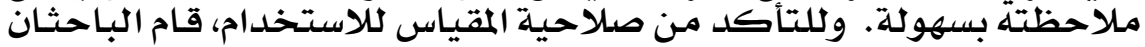
بالإجراءات التالية لضولية لضبطها:

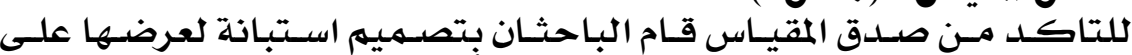

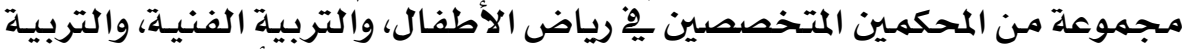

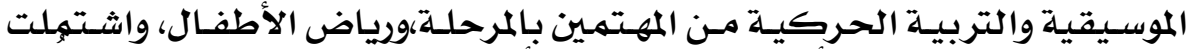

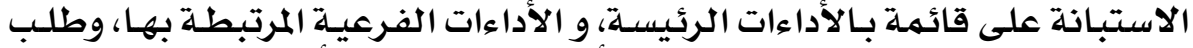

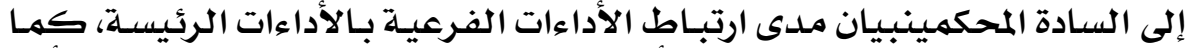

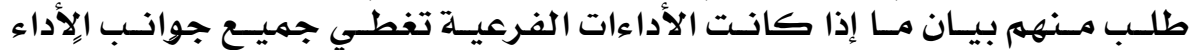

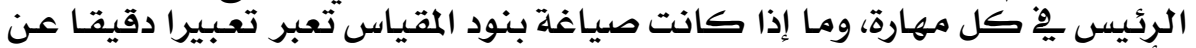

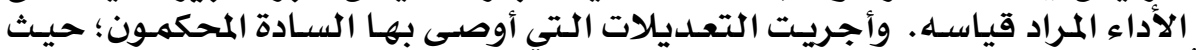

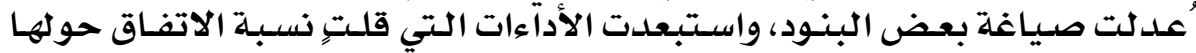

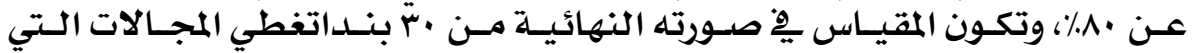
اشتهل عليها المقياس.

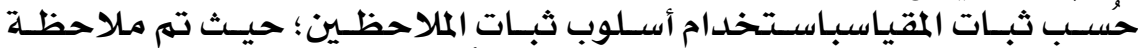

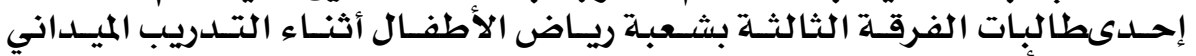

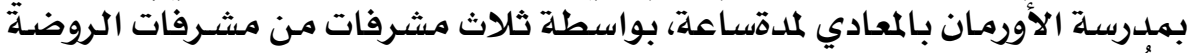

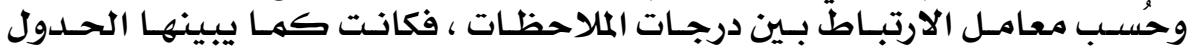
التالي:

جدول(r): معاملات الارتباط بين درجات الملاحطات الثثلاث يُ بطاقة الملاحظة

\begin{tabular}{|c|c|}
\hline معامل الارتباط & | الملاحظات \\
\hline 2091 & الآولى والثانية \\
\hline jArr & الآولى والثالثة \\
\hline JAYI & الثانيـة والثالثة \\
\hline
\end{tabular}

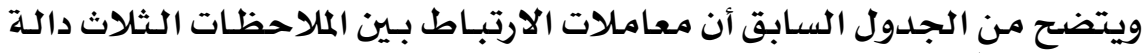

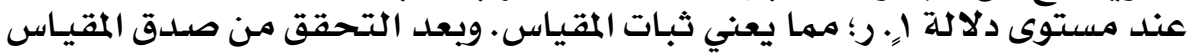

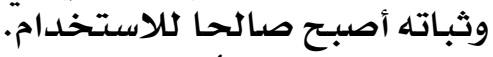

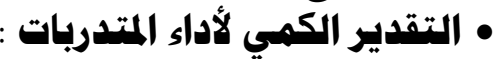

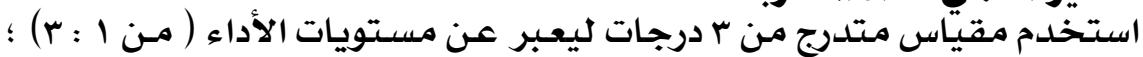

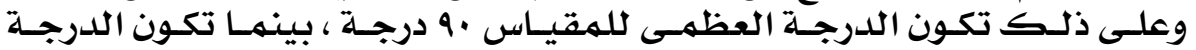

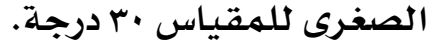

\section{9}




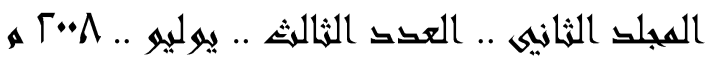

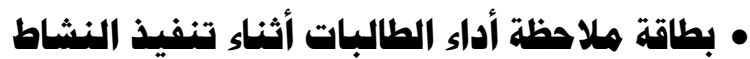

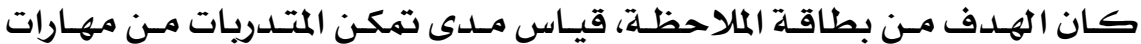

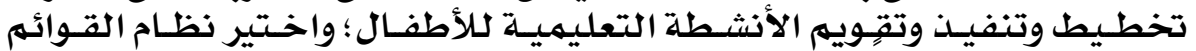

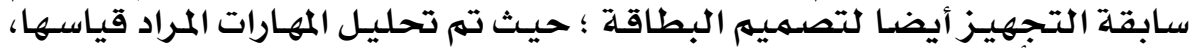

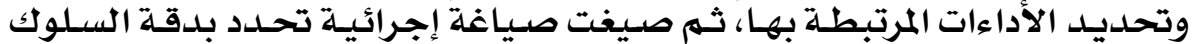

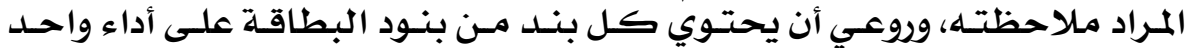

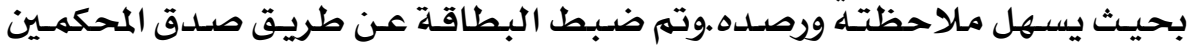

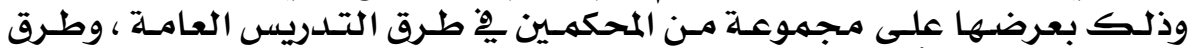

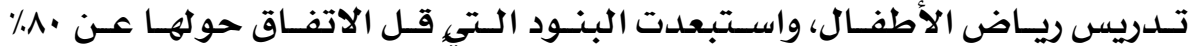

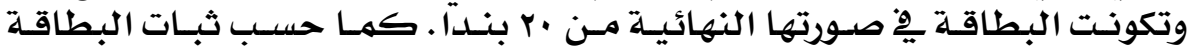

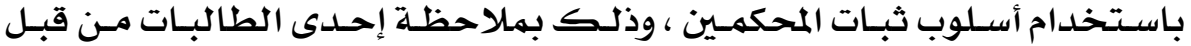

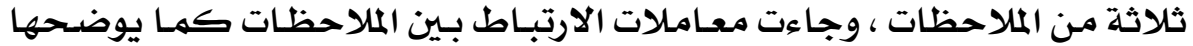

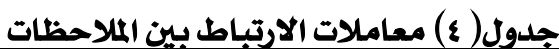

\begin{tabular}{|c|c|}
\hline معامل الارتباط & الملاحظات \\
\hline 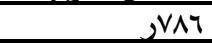 & الأولولىوالثانية \\
\hline jマą & الأولىوالثالثة \\
\hline $2 \Lambda 1 Y$ & الثانية والثالثة \\
\hline
\end{tabular}

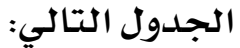

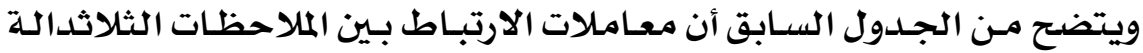

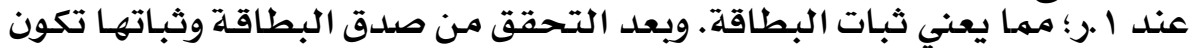

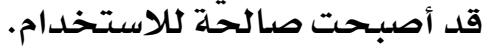

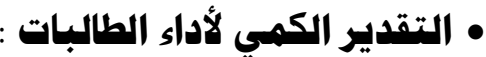

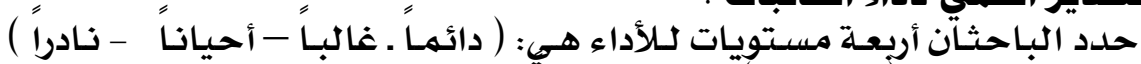

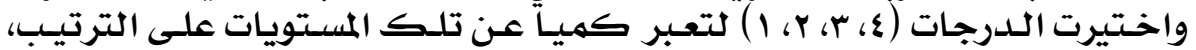

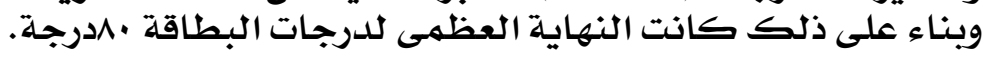

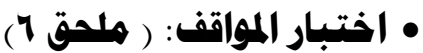

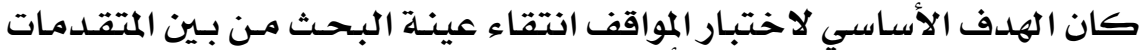

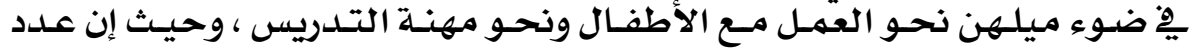

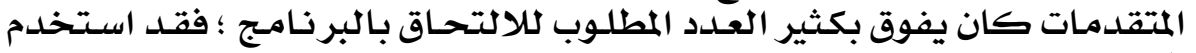

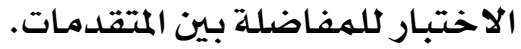

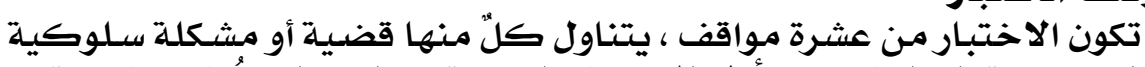

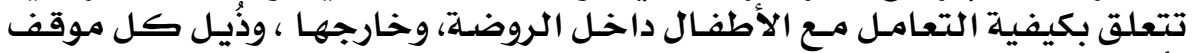

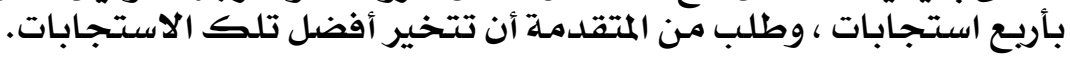

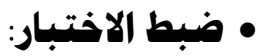

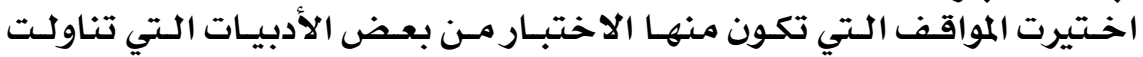

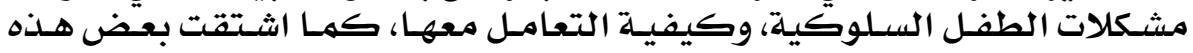

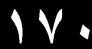

دوأسات عربية في الثزبية وعايم النففي (ASEP) 


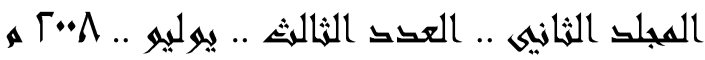

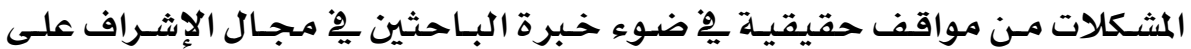

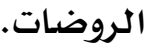

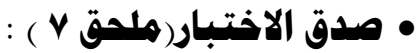

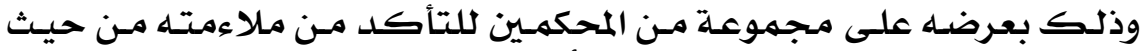

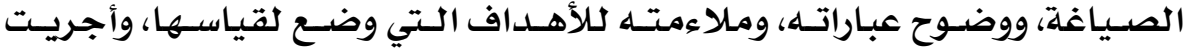

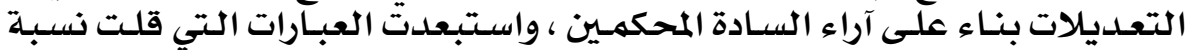

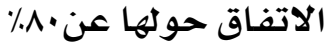

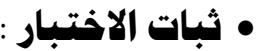

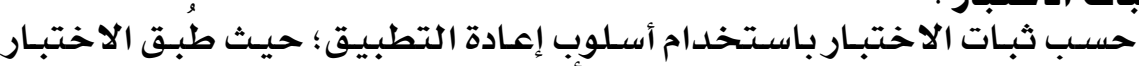

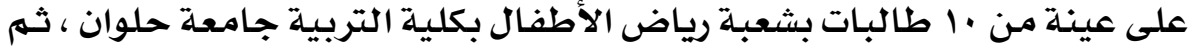

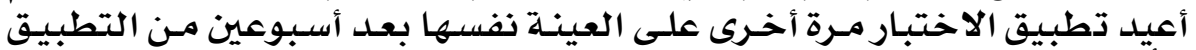

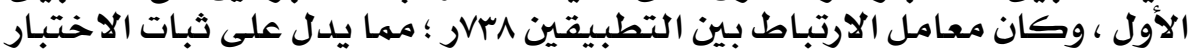
وصدلاحيته للتطبيق.

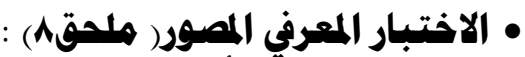

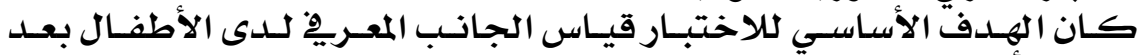

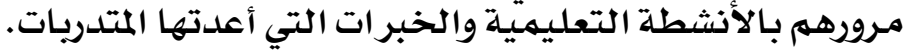

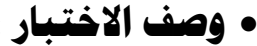

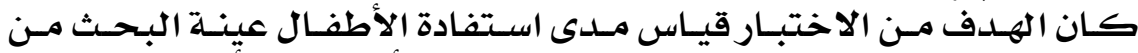

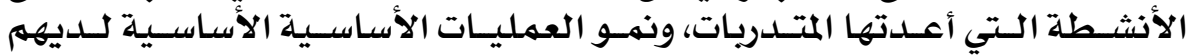

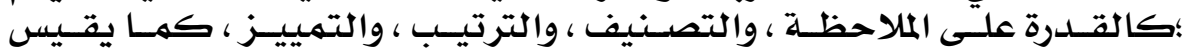

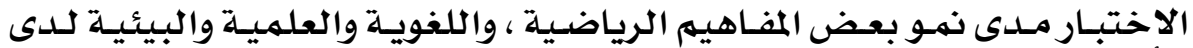

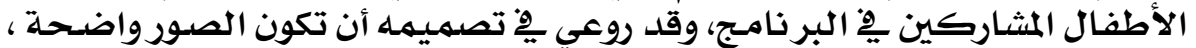

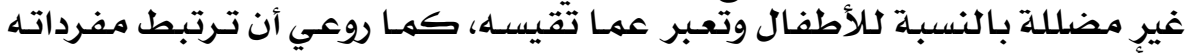

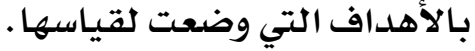

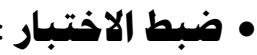

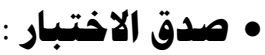

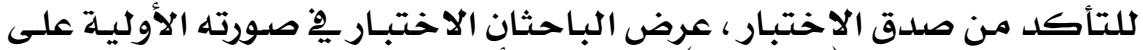

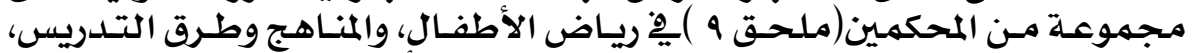

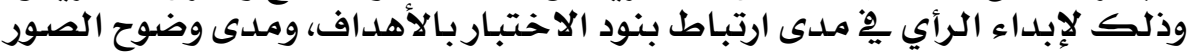

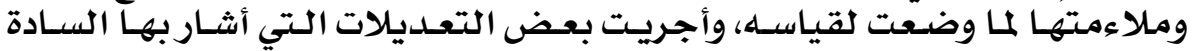

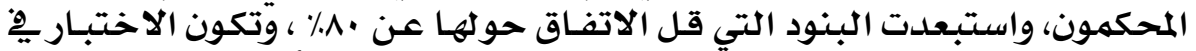

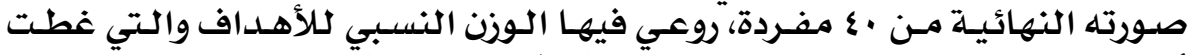

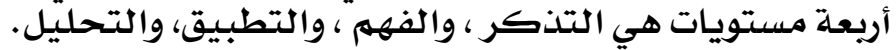

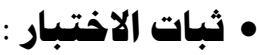

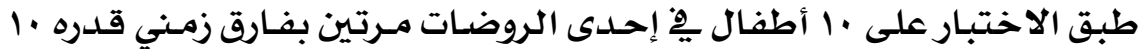

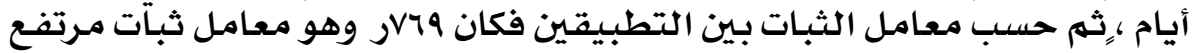

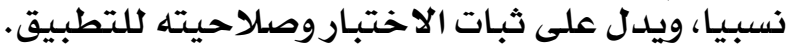




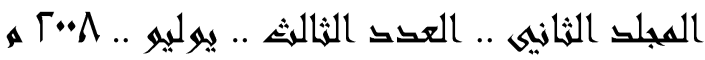

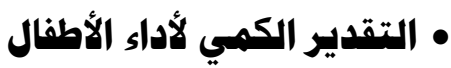

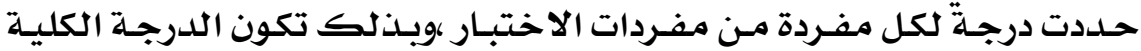

كلاختبار • • درجة درجة.

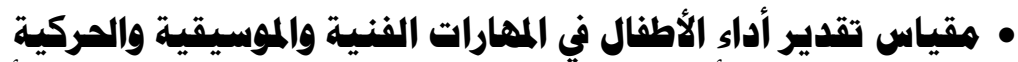

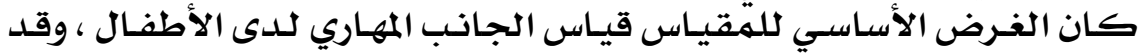

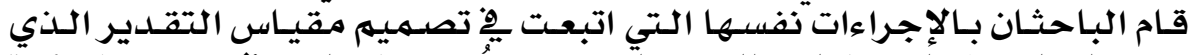

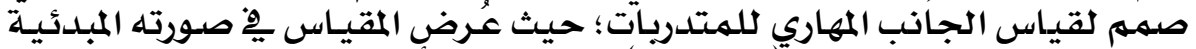

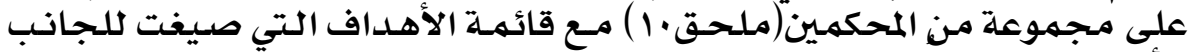

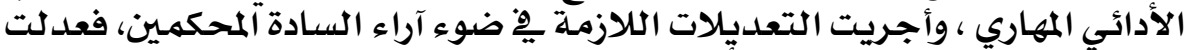

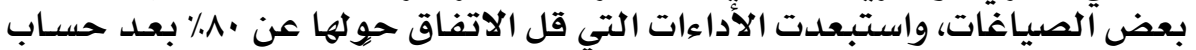

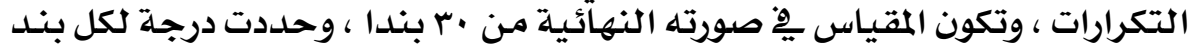

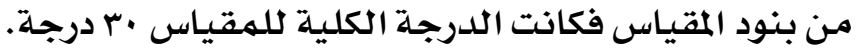

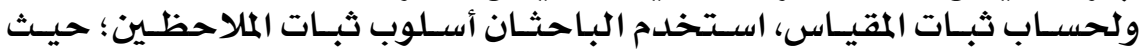

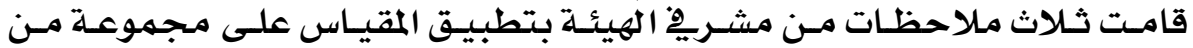

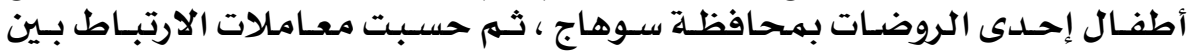

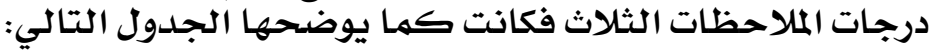

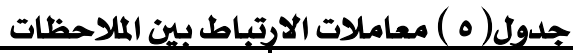

\begin{tabular}{|c|c|}
\hline معامل الارتباط & الملاحظظات \\
\hline jv70 & الأولوكوالثانية \\
\hline gror & الأولوىوالثالثة \\
\hline V $v \varepsilon$ & الثانية والثالثة \\
\hline
\end{tabular}

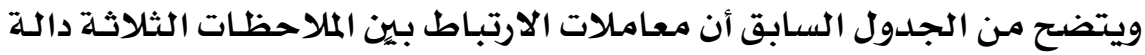

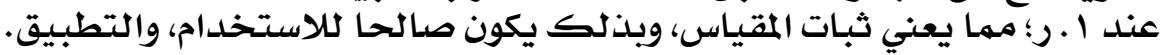

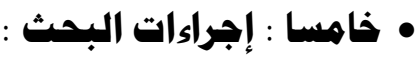

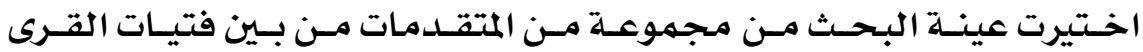

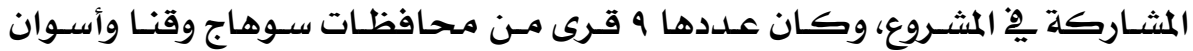

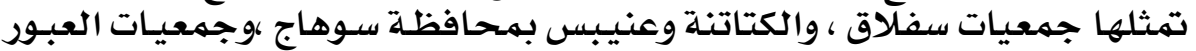

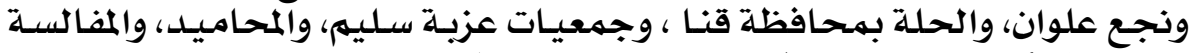

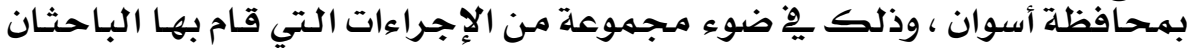

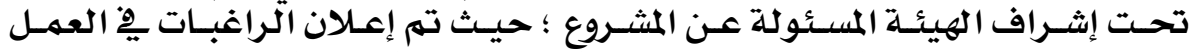

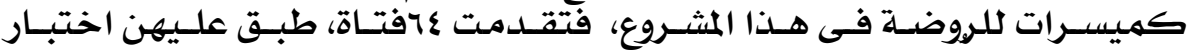

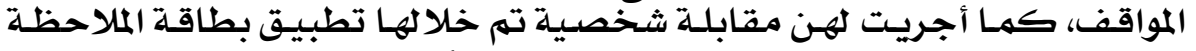

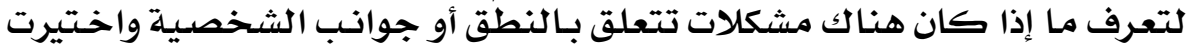

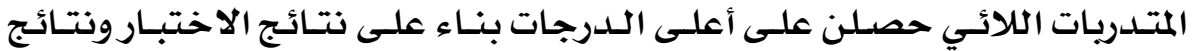

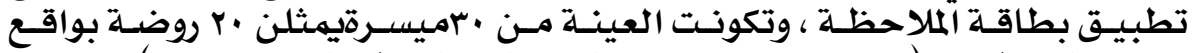

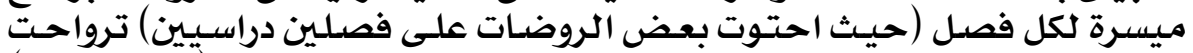

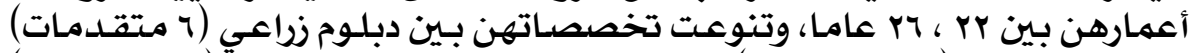

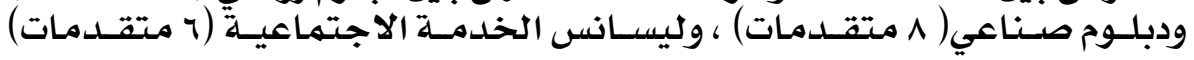

\section{IVY}

دوأسات عربية في الثزبية وعائم النفس (ASEP) 


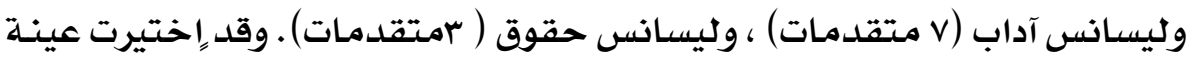

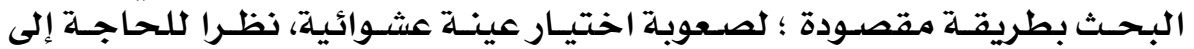

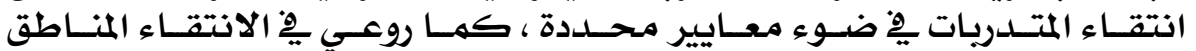

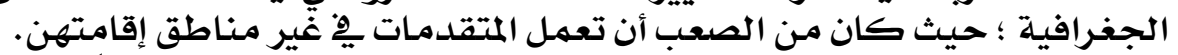

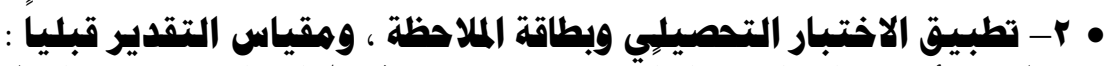

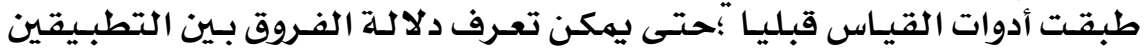

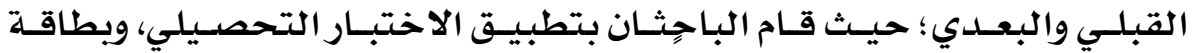

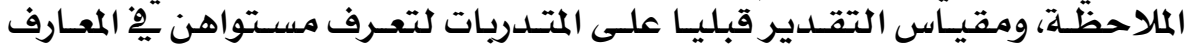

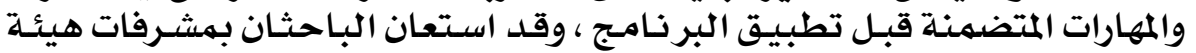

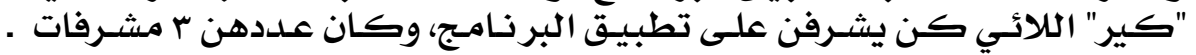

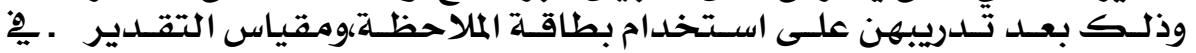

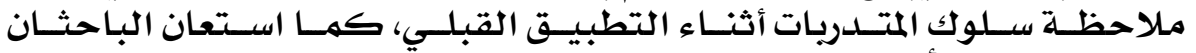

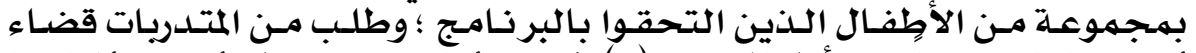

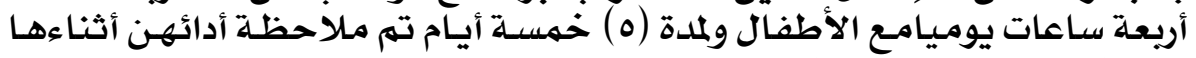

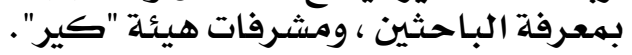

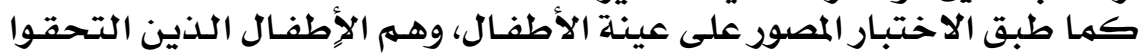

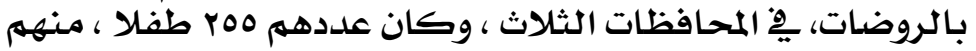

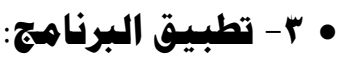

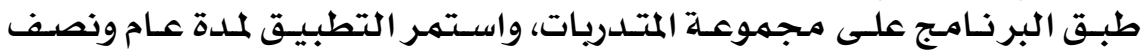

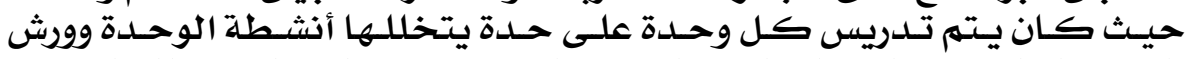

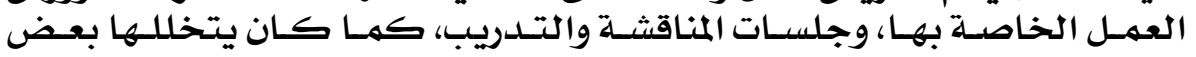

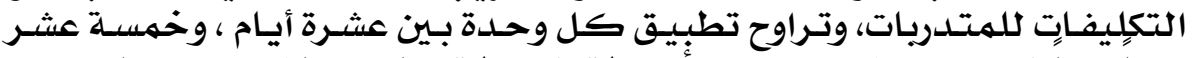

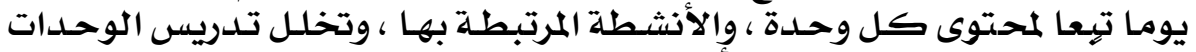

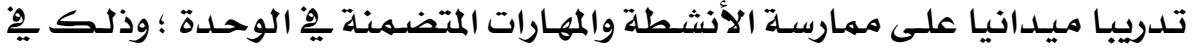

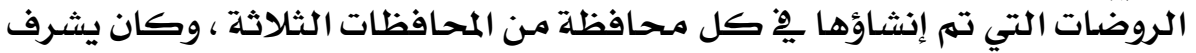

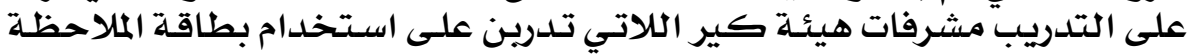

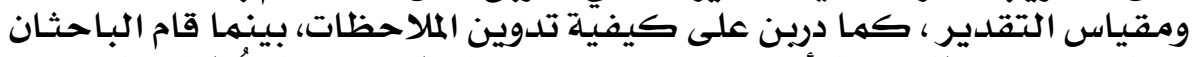

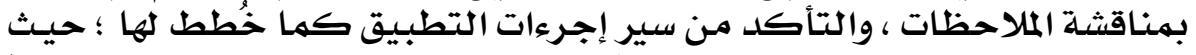

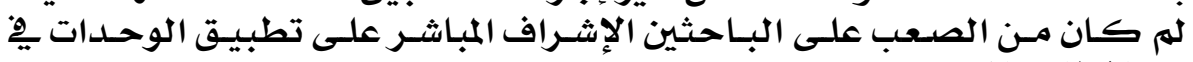
المحافظات الثلاث.

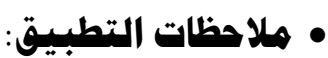

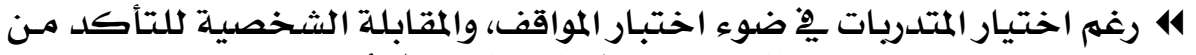

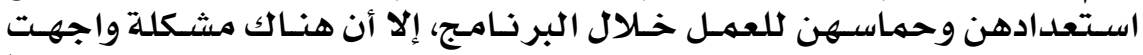

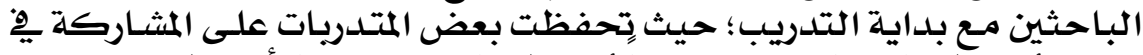

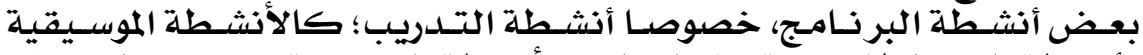

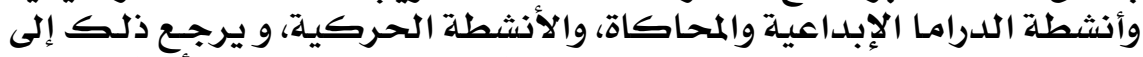

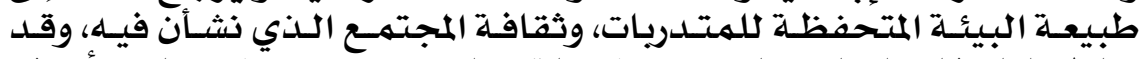

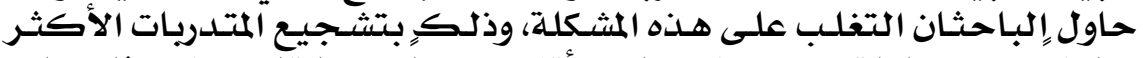

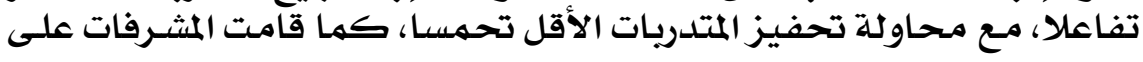

\section{IVY}




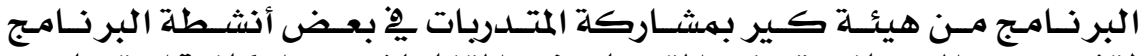

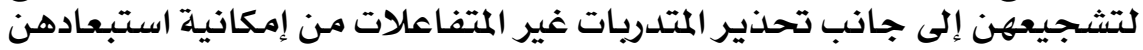

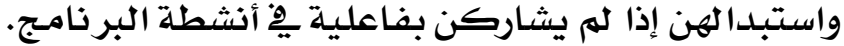

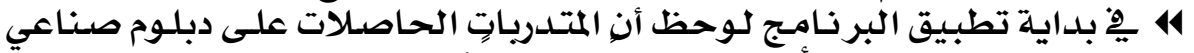

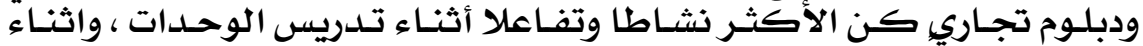

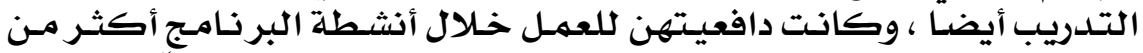

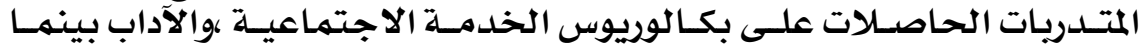

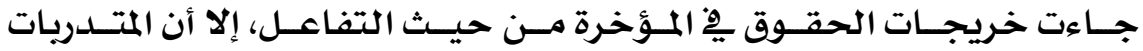

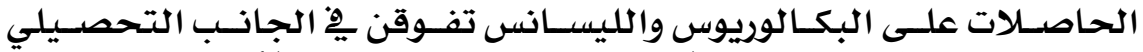

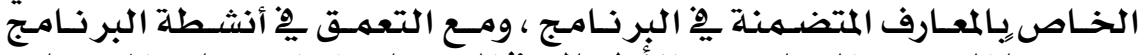

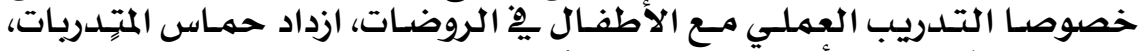

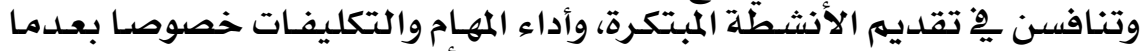

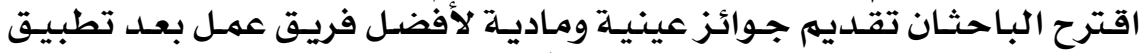

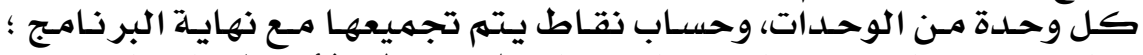

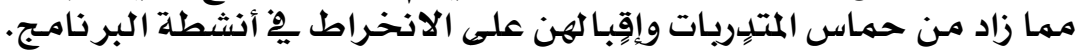

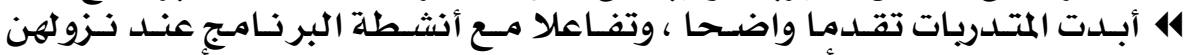

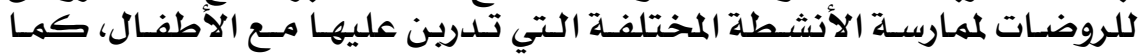

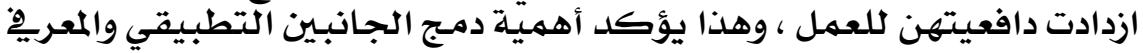
للببرنامجر.

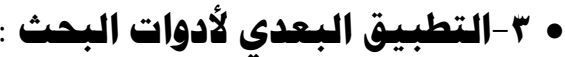

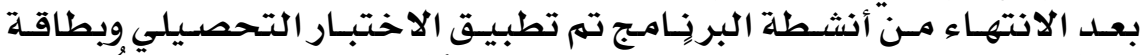

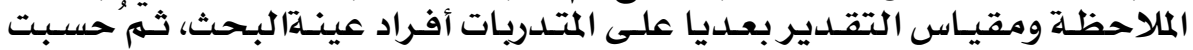

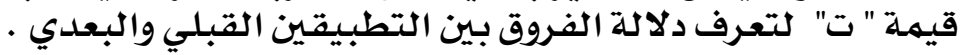

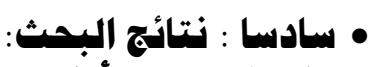

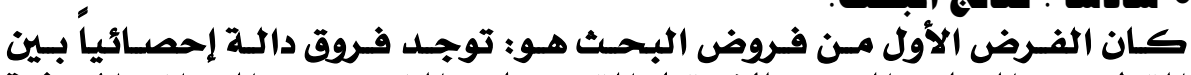

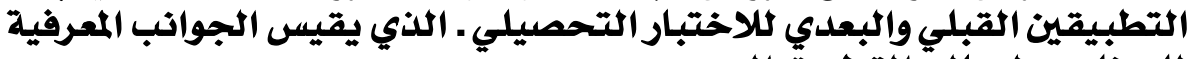

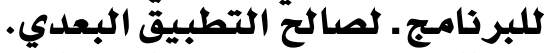

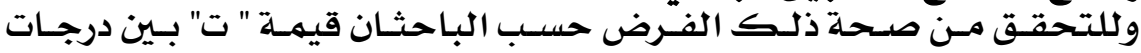

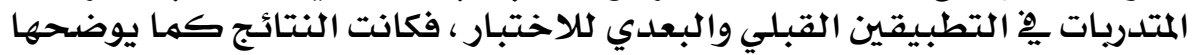

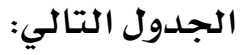
جدول(†): قيمة (ت) لنتائج التطبيقين القبلي والبعدى للاختبار التحصيلي،

\begin{tabular}{|c|c|c|c|c|c|c|}
\hline مستوى الدلالدة & ت & د ح & حم & م & ن & البيان \\
\hline 3.1 & 78.80 & Yq & $0 .\{0$ & $\frac{\text { A.0. }}{\text { V.. }}$ & $r$. & قعلدى \\
\hline
\end{tabular}

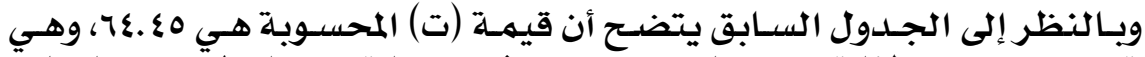

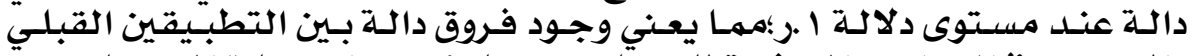

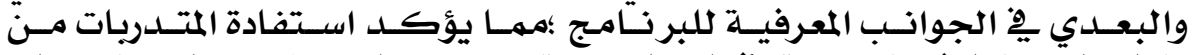

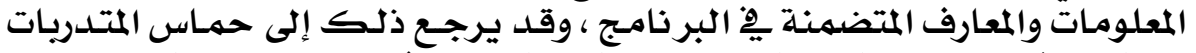

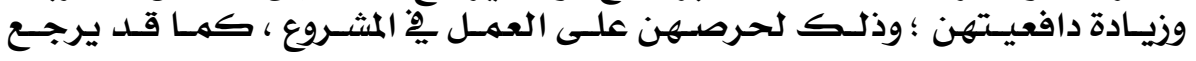

\section{$1 \vee \varepsilon$}




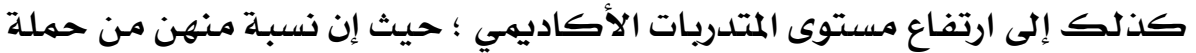

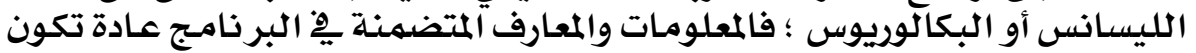

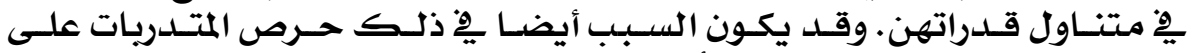

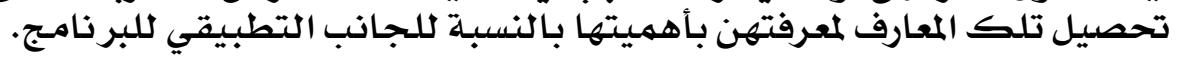

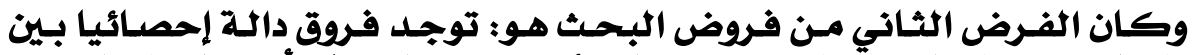

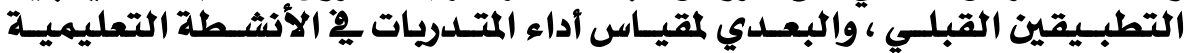

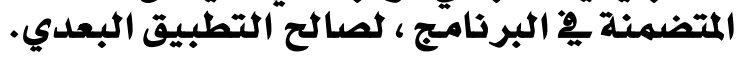

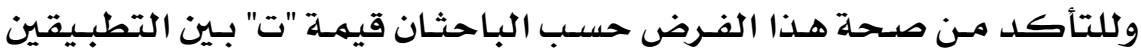

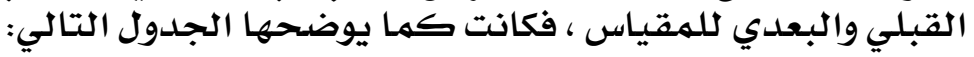

\begin{tabular}{|c|c|c|c|c|c|c|}
\hline مستوى الدلالة & $\Xi$ & د & ז م & a & $\dot{ن}$ & الليـان \\
\hline j.1 & $V \cdot . r Y$ & rq & r.99 & $7.7 \mathrm{~V}$ & $\mu_{\text {. }}$ & قبلى \\
\hline
\end{tabular}

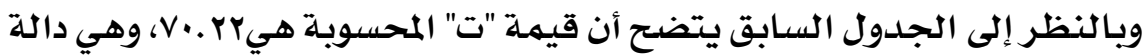

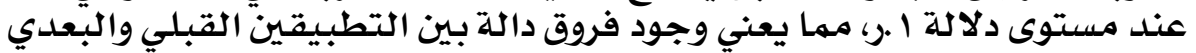

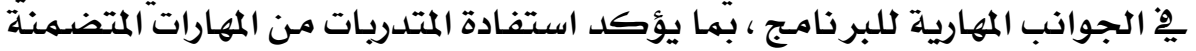

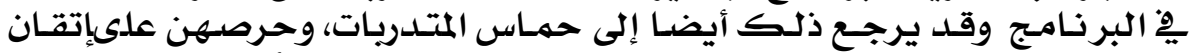

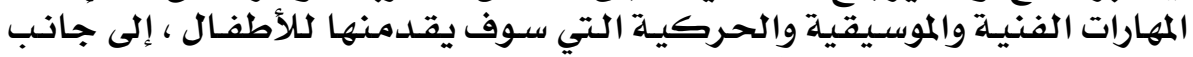

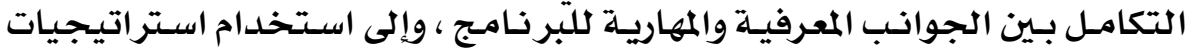

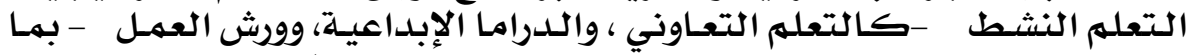

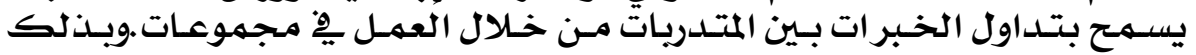

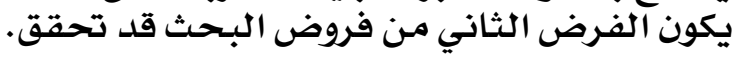

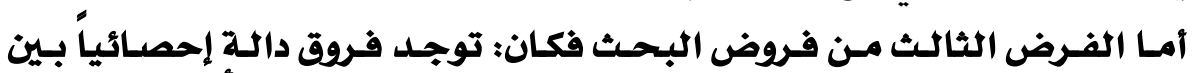

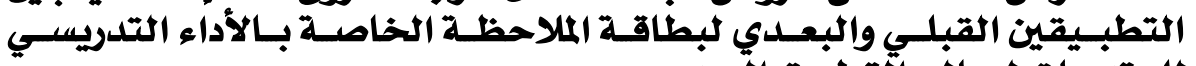

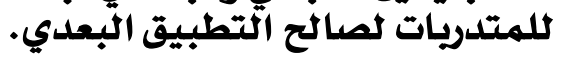

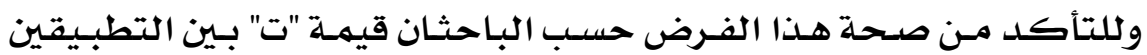

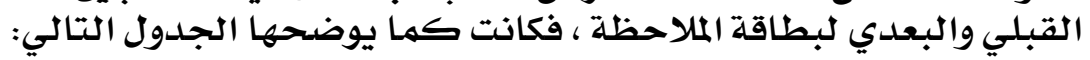

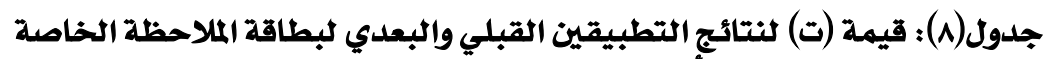
بالأداء التدريسي للمثئدريات

\begin{tabular}{|c|c|c|c|c|c|}
\hline مستوى الدلالة & $\Xi$ & د ح & م & $\dot{ن}$ & البيان \\
\hline \multirow{2}{*}{3.1} & \multirow[t]{2}{*}{$01 .\{2$} & \multirow[t]{2}{*}{ rq } & A.Tr & \multirow[t]{2}{*}{$r}$. & قبلى \\
\hline & & & Tr.WV & & بعلىي \\
\hline
\end{tabular}

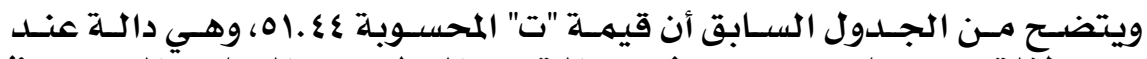

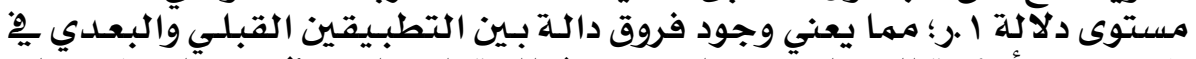

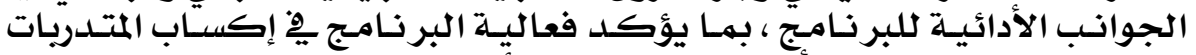

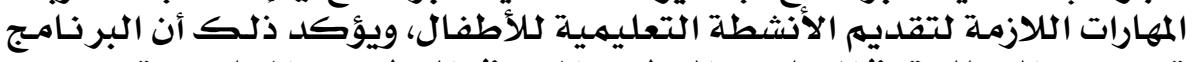

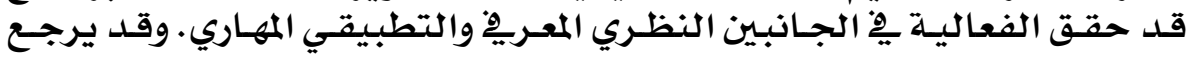

\section{$1 \vee 0$}

دوأسات عربية في التزبية وعنم ألنفي (ASEP) 


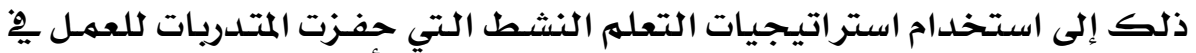

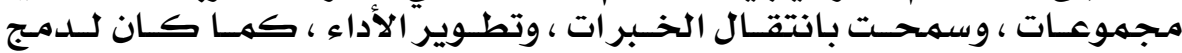

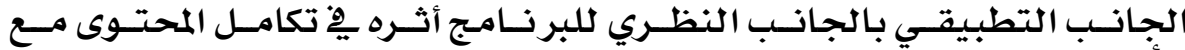

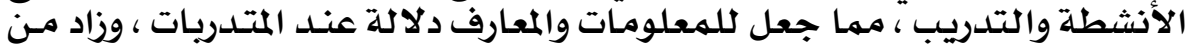

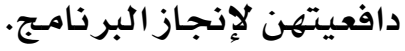

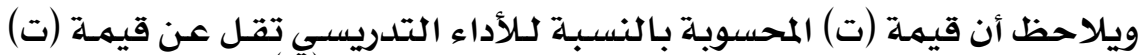

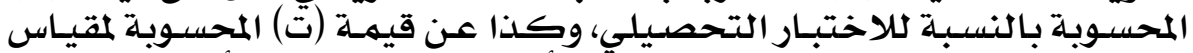

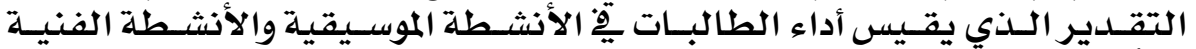

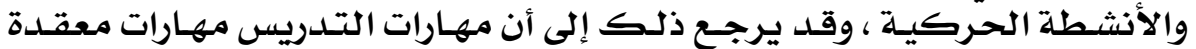

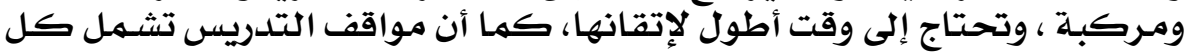

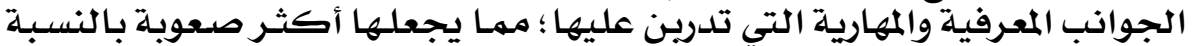

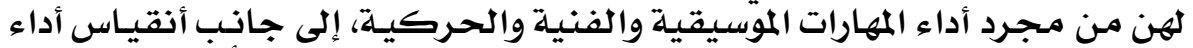

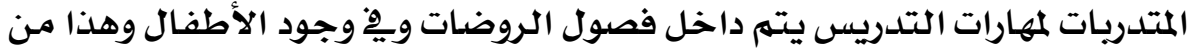
شأنه أن يؤثر على مستورى الدتئن أدائهن.

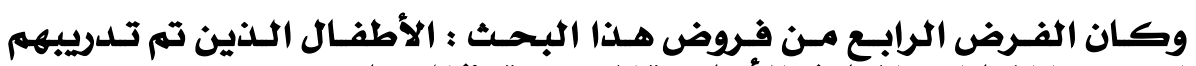

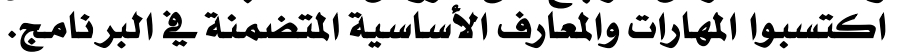

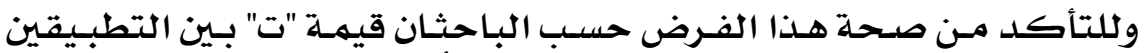

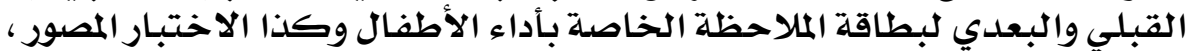

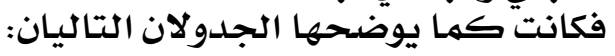

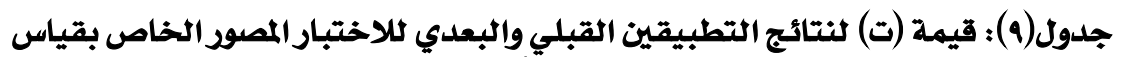
الجانب المعربِ نالأطفال

\begin{tabular}{|c|c|c|c|c|c|}
\hline مستوى الدلالة & ت & حم & P & $\dot{ن}$ & الييان \\
\hline \multirow{2}{*}{3.0} & \multirow{2}{*}{ ITY.Yr } & \multirow{2}{*}{ r.r.. } & $\varepsilon . M_{1}$ & \multirow{2}{*}{ Yo० } & قيلى \\
\hline & & & YA.O. & & بعلدي \\
\hline
\end{tabular}

جدول( ـ ):قيمة (ت) لنتائج التطبيقين القبلي والبعدي لبطاقة الملاحظة الخاصة بقياس الجانب المهاري لكلأطفال

\begin{tabular}{|c|c|c|c|c|c|}
\hline مستوى الدلاكة & ت & ح م & م & ن & البيان \\
\hline \multirow{2}{*}{3.0} & \multirow{2}{*}{ 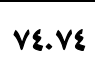 } & \multirow{2}{*}{ r.Ar } & $r .99$ & \multirow{2}{*}{ Yoo } & قيلى \\
\hline & & & Y1.91 & & بعلى \\
\hline
\end{tabular}

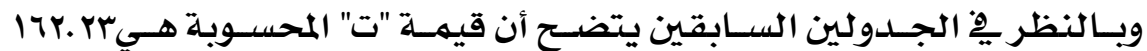

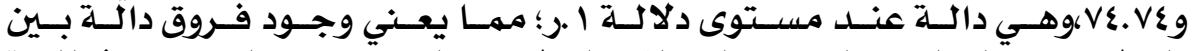

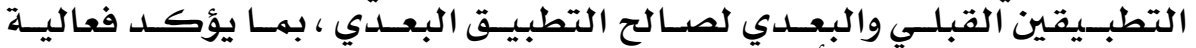

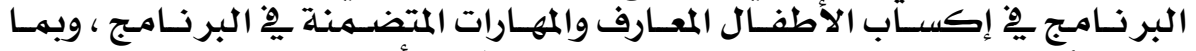

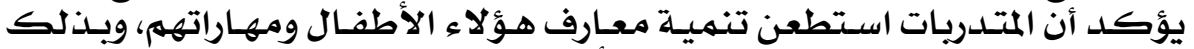

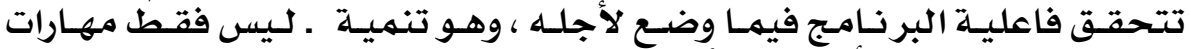

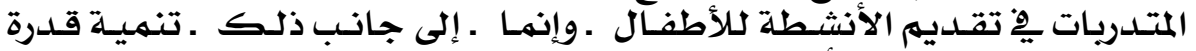

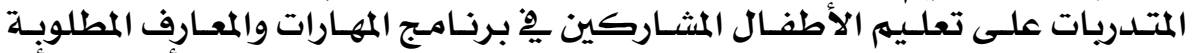

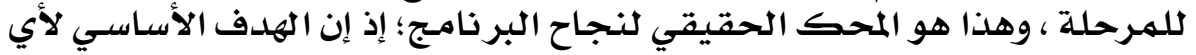

\section{7}


برنامجر لتدريب المعلهم ، هو مدىى ما يحققه من عائد لدى المتعلمـين وليس للهعلسم فقط.

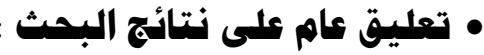

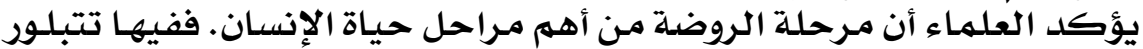

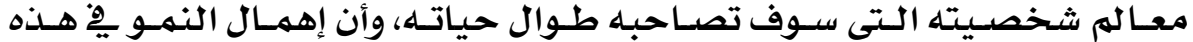

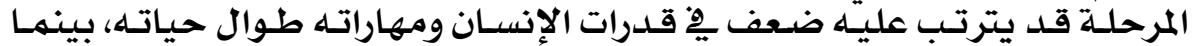

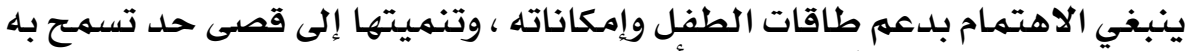

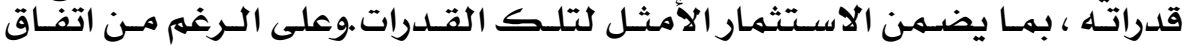

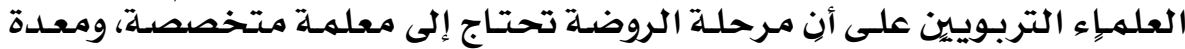

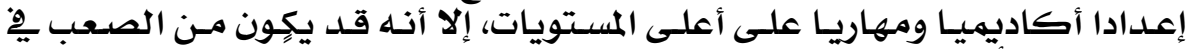

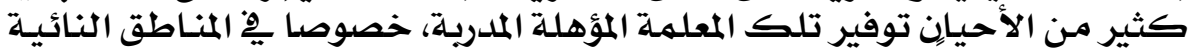

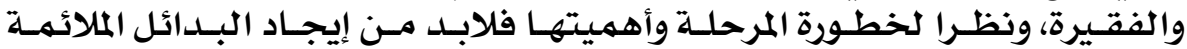

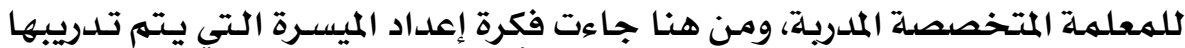

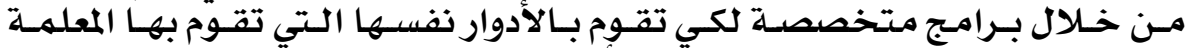

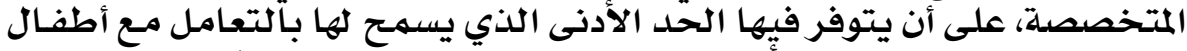

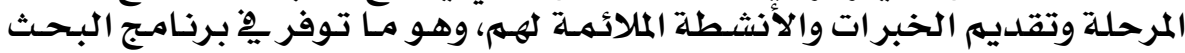

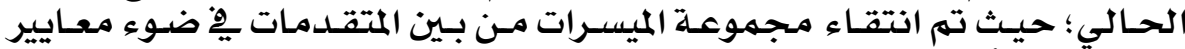

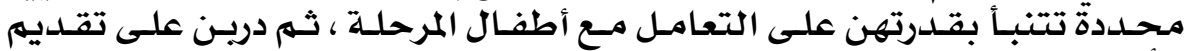

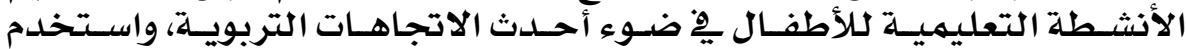

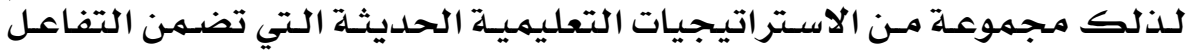

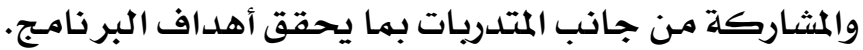

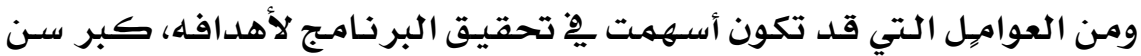

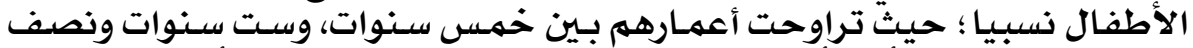

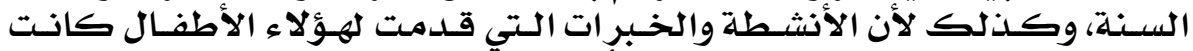

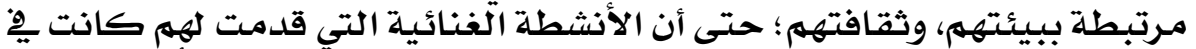

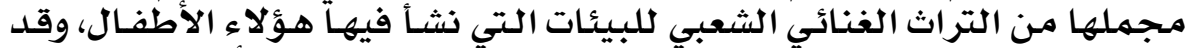

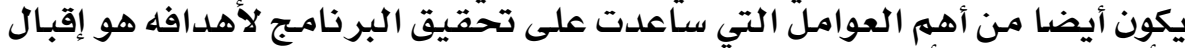

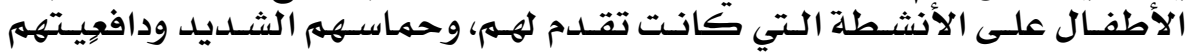

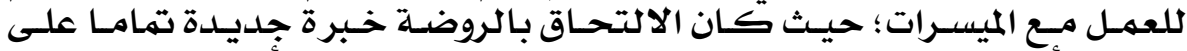

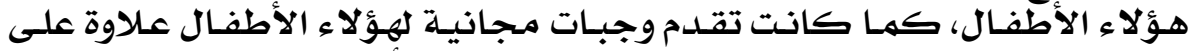

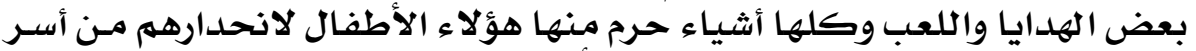

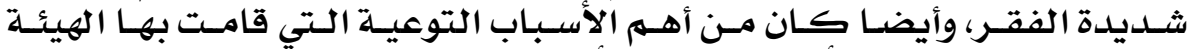

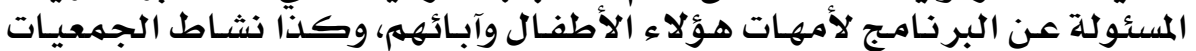

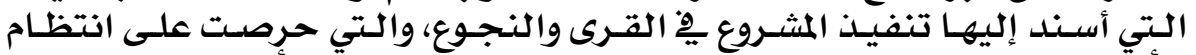

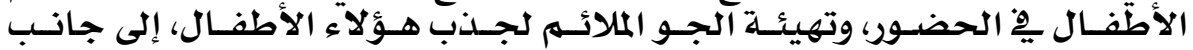

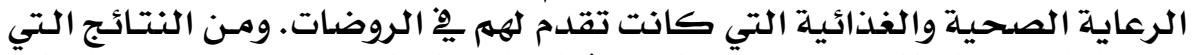

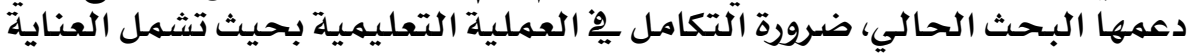

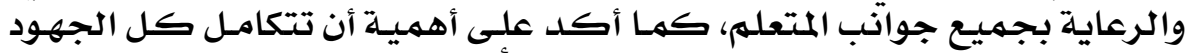

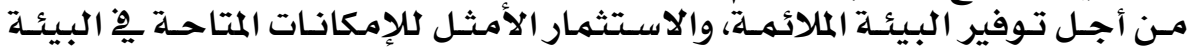




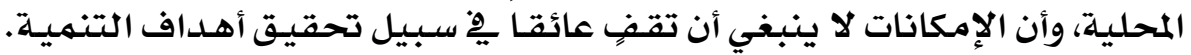

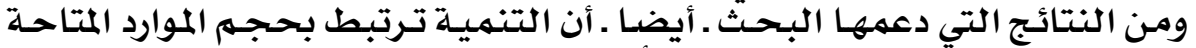

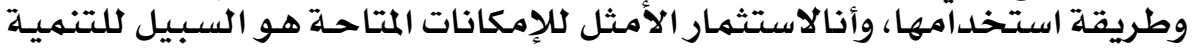

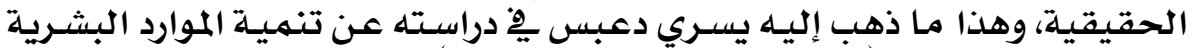

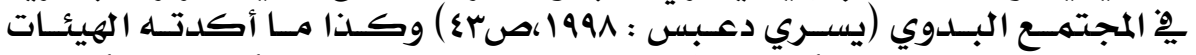

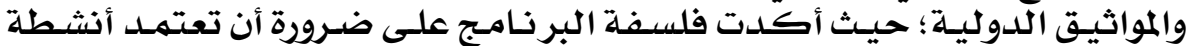

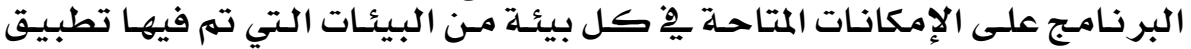

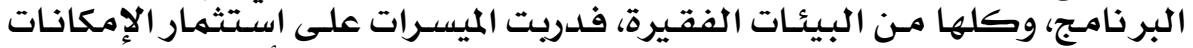

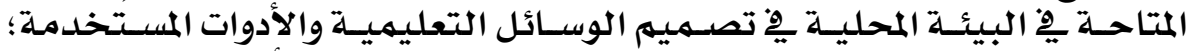

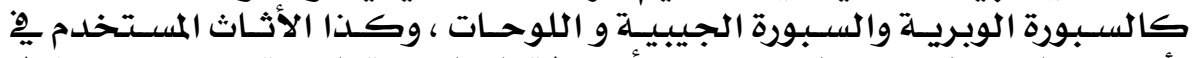

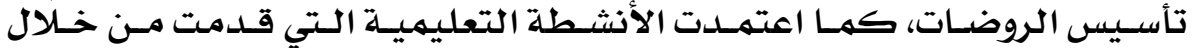

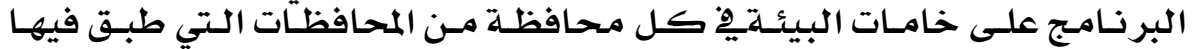

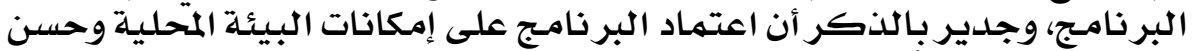

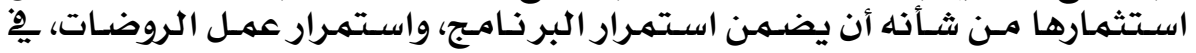

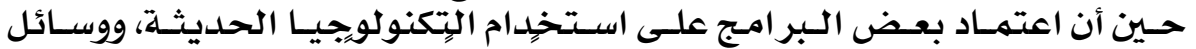

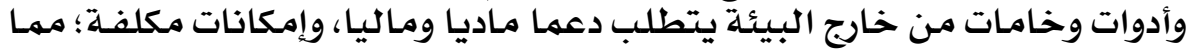

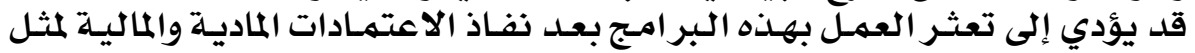

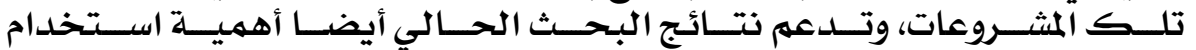

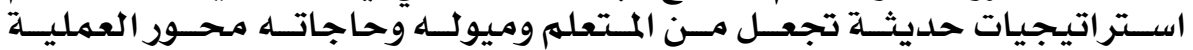

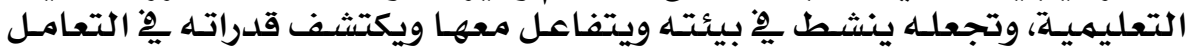
مع هذه البيئة.

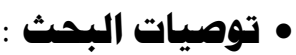

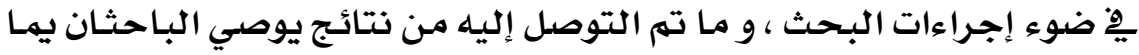

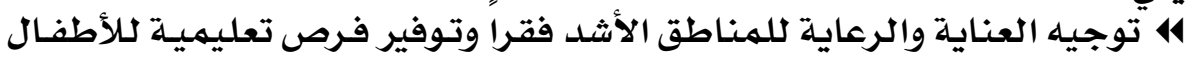

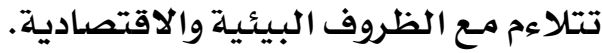

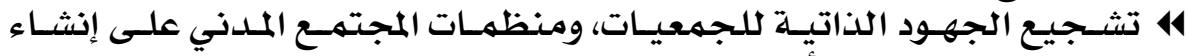

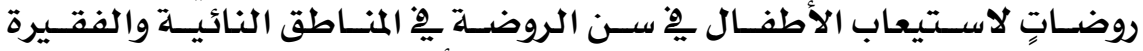

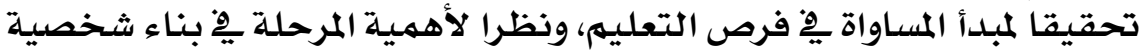

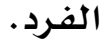

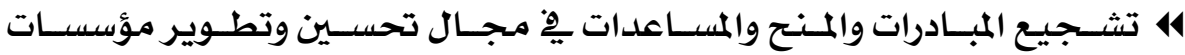

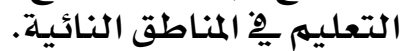

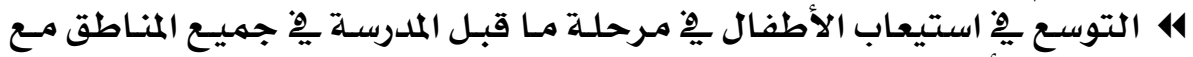

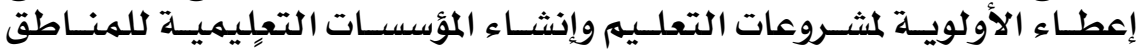

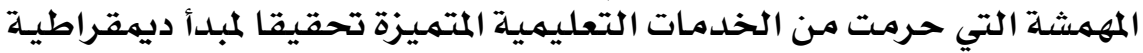
التعليه.

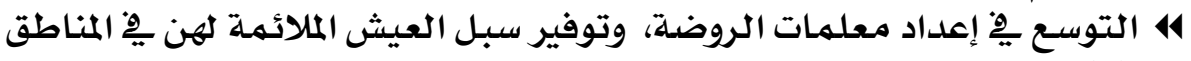
النائية.

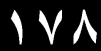




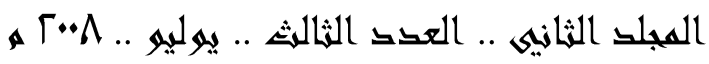

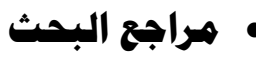

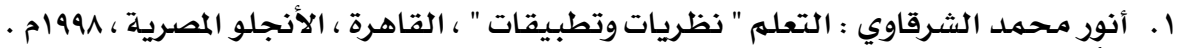

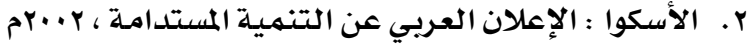
http://www.escwa.un.org/arabic/information/meetings/events/wssd/pa .pers.html

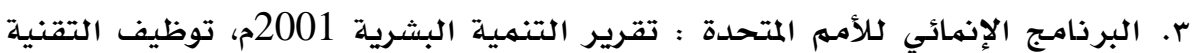

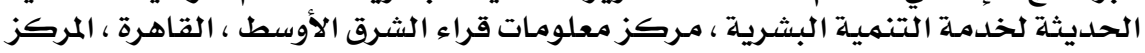
•r... ،

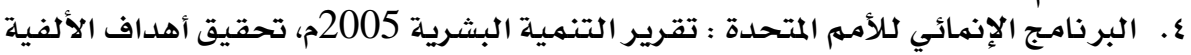

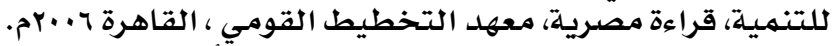

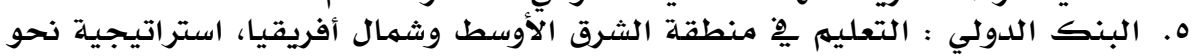

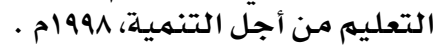

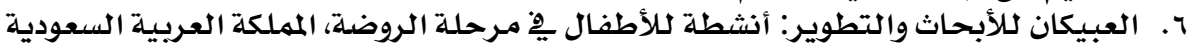

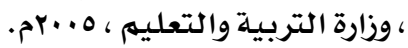

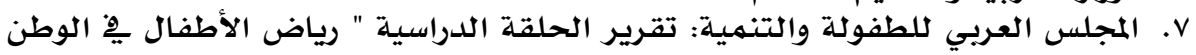

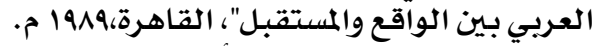

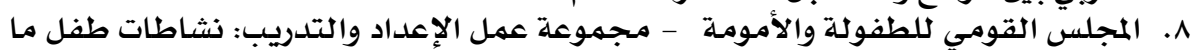

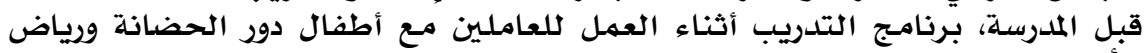

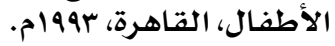

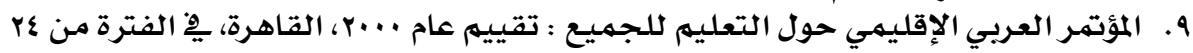

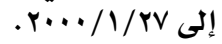

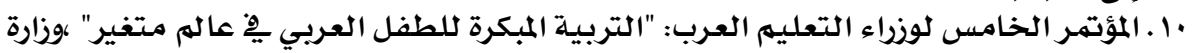

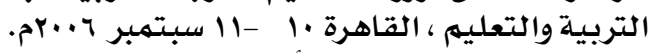

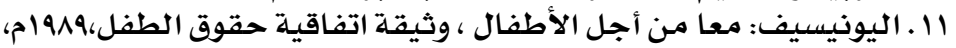
www.unicef.org/arabic/crc/files/UNICEF_Big_Poster.

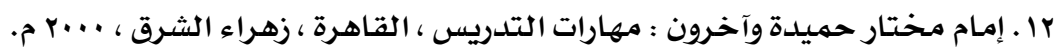

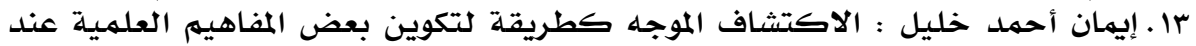

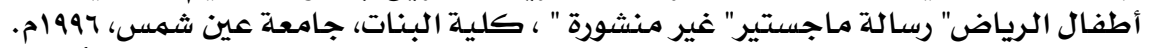

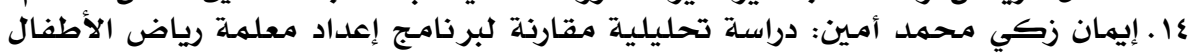

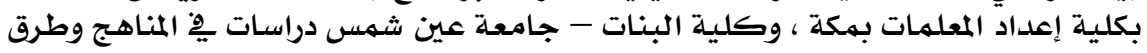

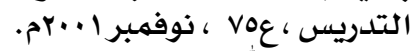

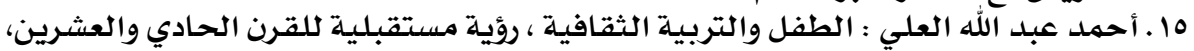

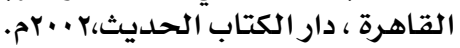

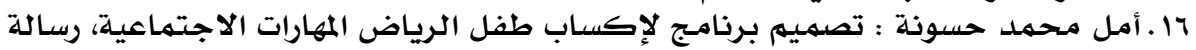

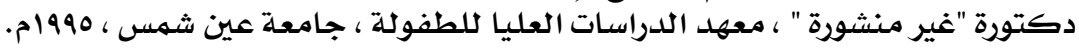

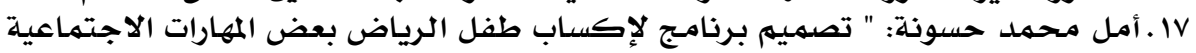

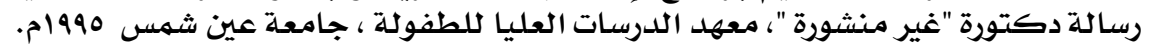

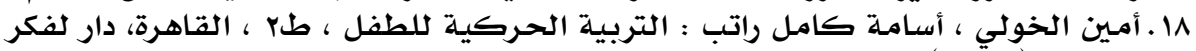

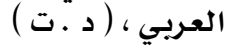

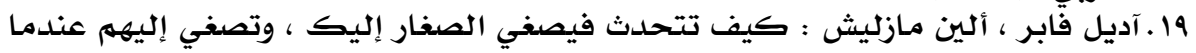

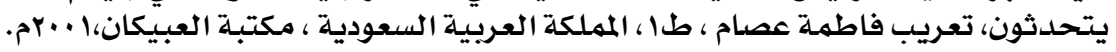

\section{$1 \vee 9$}


•r. آمال صادق ، فؤاد أبو حطب : علم النفس التربوي ، طه ، القاهرة ، الأنجلو المصرية

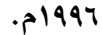
اب.آمال صادق ، و أميمة أمين :الخبرات الموسيقية ِِّ الحضانة ،ورياض الأطفال، القاهرة

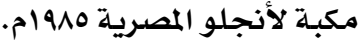

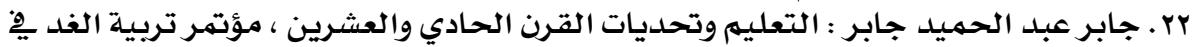

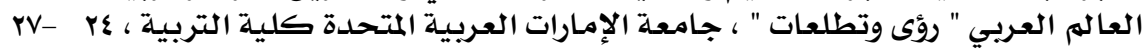

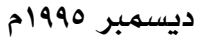

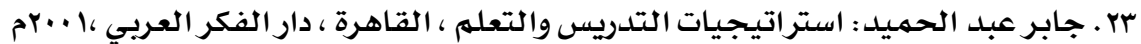

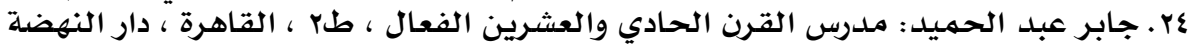

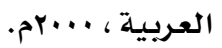

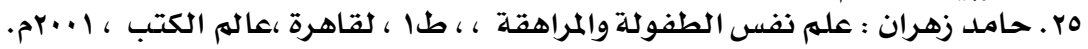

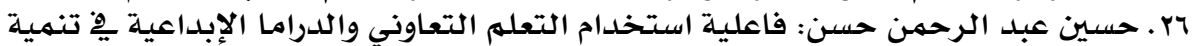

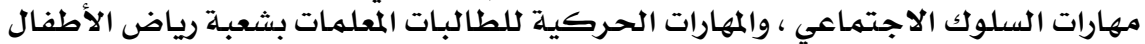

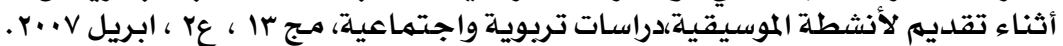

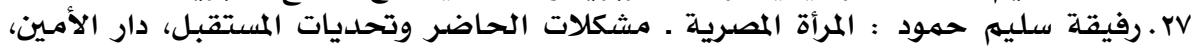

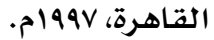

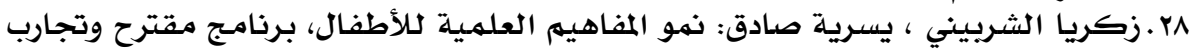

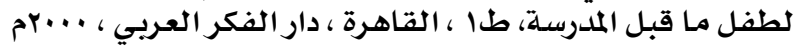

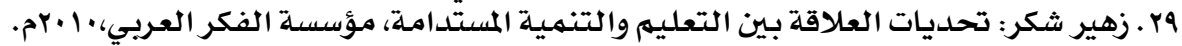

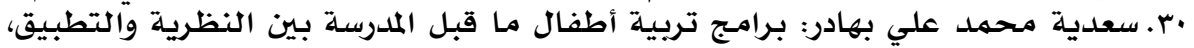

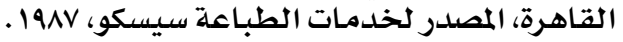

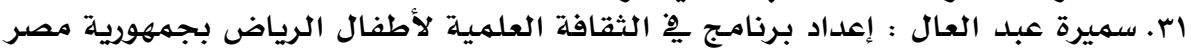

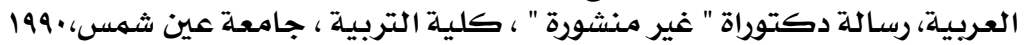

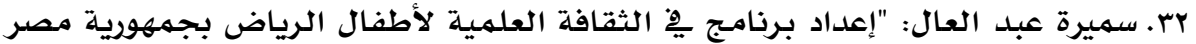

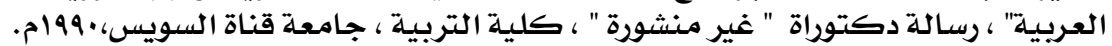

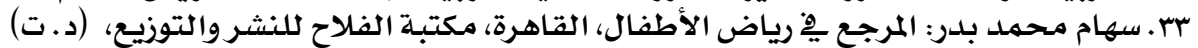

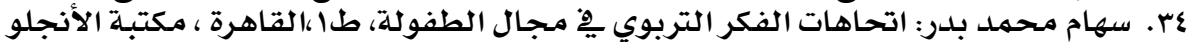

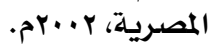

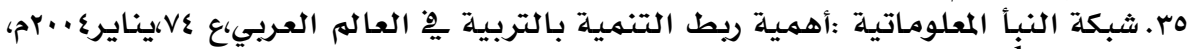
Www.annabaa.org

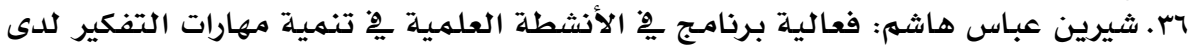

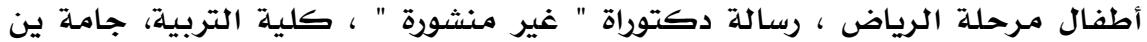

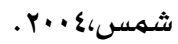
PV.rV

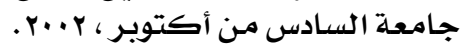

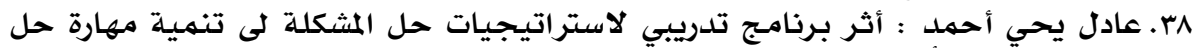

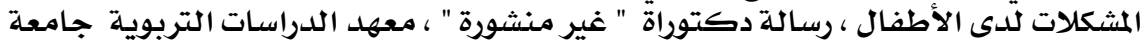
9q.عباس سرحان : أهمية ريط التنمية بالتربية ِِّ العالم العربي ، شبكة البنأ المعلوماتية

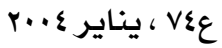

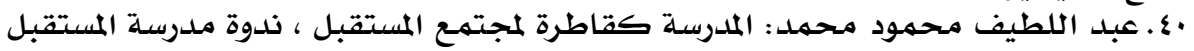

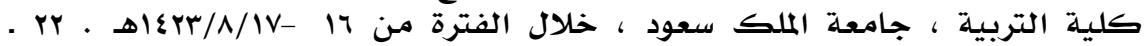
مr..r/l./rr 


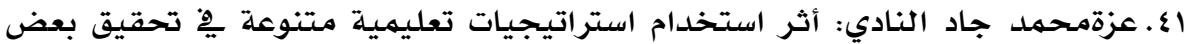

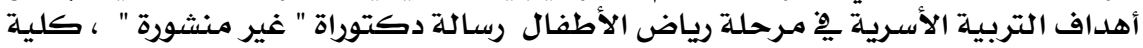

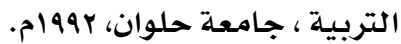

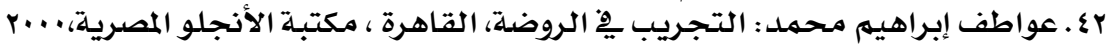

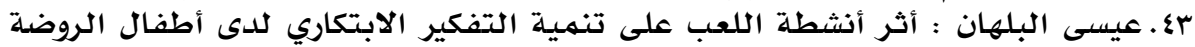

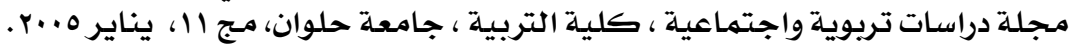

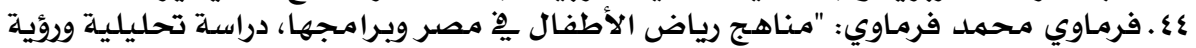

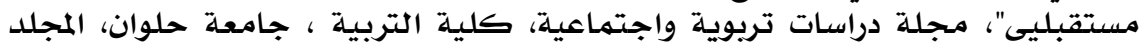

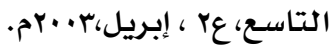

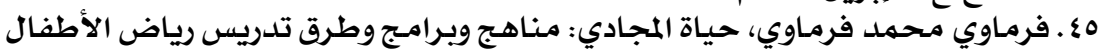

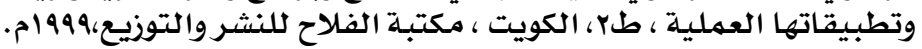

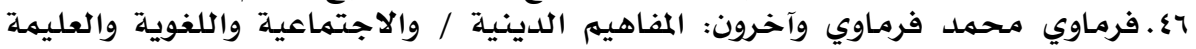

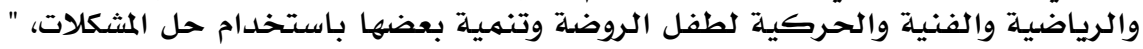

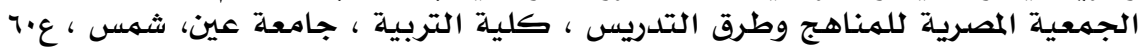

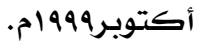

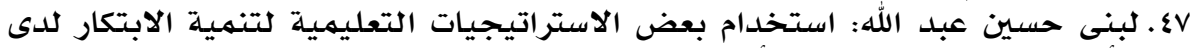

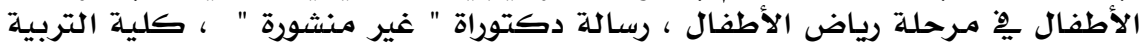

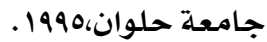

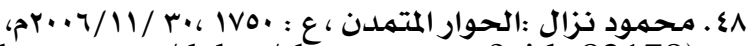
(http://www.ahewar.org/debat/show.art.asp?aid=82178)

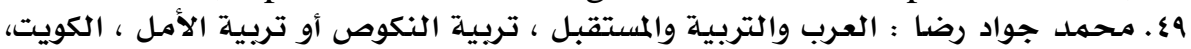

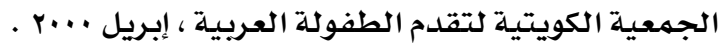

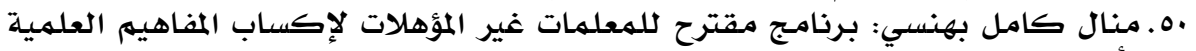

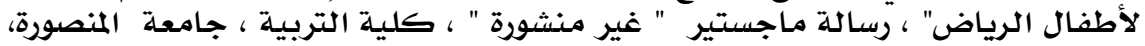
. r.. q

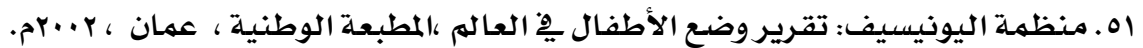

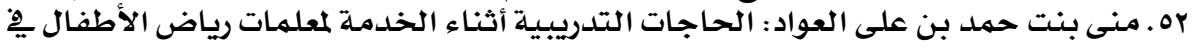

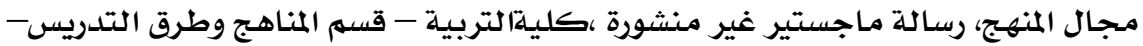

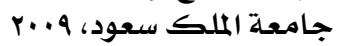

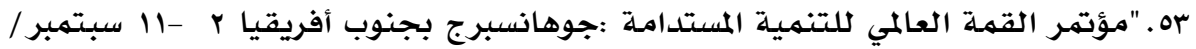

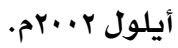

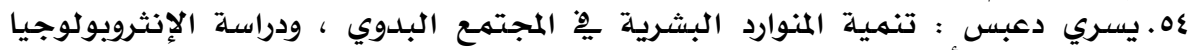

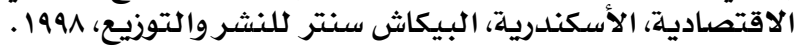

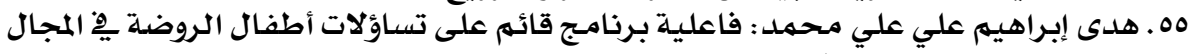

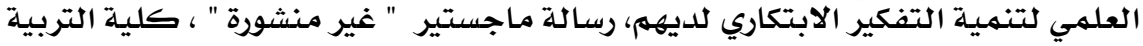

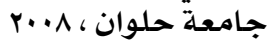

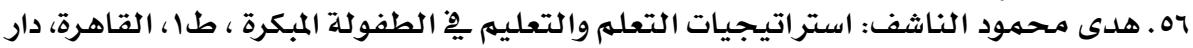

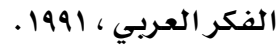

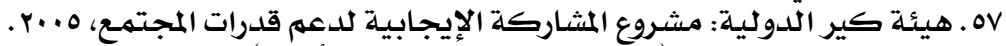

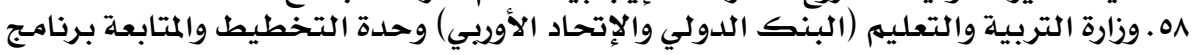

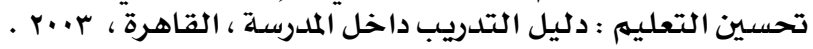

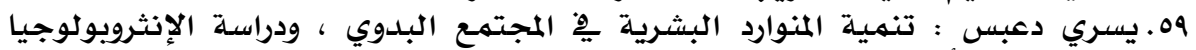

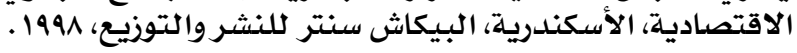


•7. يوسف خليفة غراب: دور الحضانة ورياض الأطفال، القاهرة مطبعة الموسكي، ( د ـ ت )

61. Barbare D. Early Childhood Education Creative Learning Activities, N Y, MacMillan publisher, 1998.

62. Bruce Edmonds: What is Complexity? The Philosophy of Complexity to Some Examples in Evolution, Manchester University, Center for policy Modeling, 1995.

63. C., Lewisa\& Blumenthal, R. : "Children Learn to think and create through Art", the Education of Young Children Journal, Vol 62, No. 5,2007

64. Eve-Marie, A. :Curriculum For Young Children, Thomson Delmar Learning, 2000.

65. Herr, Judy : Working With Young Children. South Holland Wilcox Company Inc., 1990

66. L. Essa, Eva: Introduction to Early Childhood Education,4th ED., Thomson Delmar Learning 2004.

67. Razik, Taher, and Diaa El-Din A. Zaher. "Egypt." In Issues and Problems in Teacher Education: An International Handbook, edited by Howard B. Leavitt, 91-108. New York: Greenwood Press, 1992.

68. Richards. Alan. "Higher Education in Egypt." Education and Employment Working Papers (WPS), no. 862. Washington, DC: World Bank, 1992.

69. Shaw-Smith, Peter. "Egyptians Welcome British Initiative." Times (London) Higher Education Supplement, 27 October 2000.

70. Soliman, Azza Abdel-Aziz. The Current Status of Pre-University Education and Its Regional Disparity in Egypt. Cairo Demographic Center, 1994.

71. Wise, Michael, and Anthony Olden, ed. Information and Libraries in the Arab World. London: Library Association, 1994.

\section{潾洸溇溇垱}

